
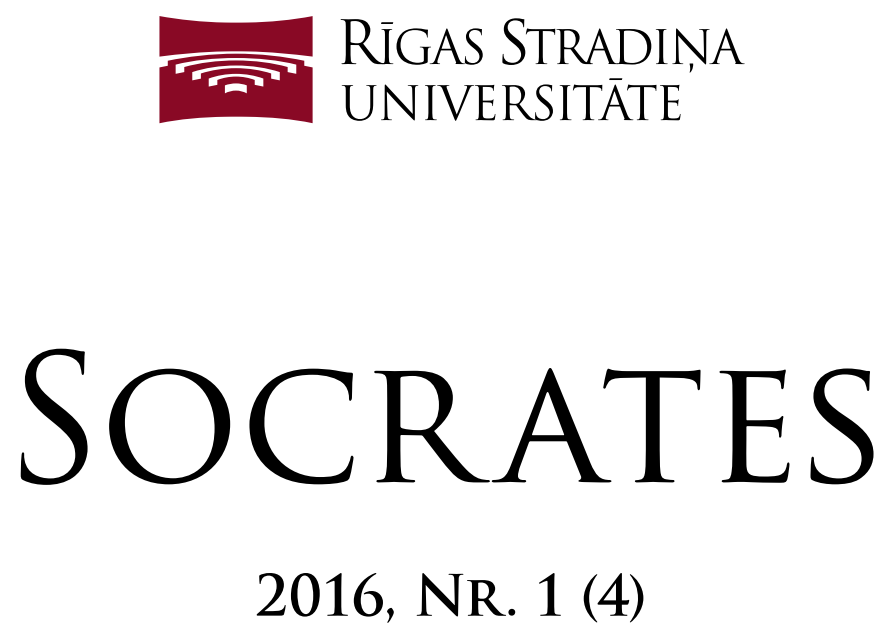

Rīgas Stradiṇa universitātes

Juridiskās fakultātes elektroniskais juridisko zinātnisko rakstu žurnāls

Rīga Stradiṇš University Faculty of Law

Electronic Scientific Journal of Law

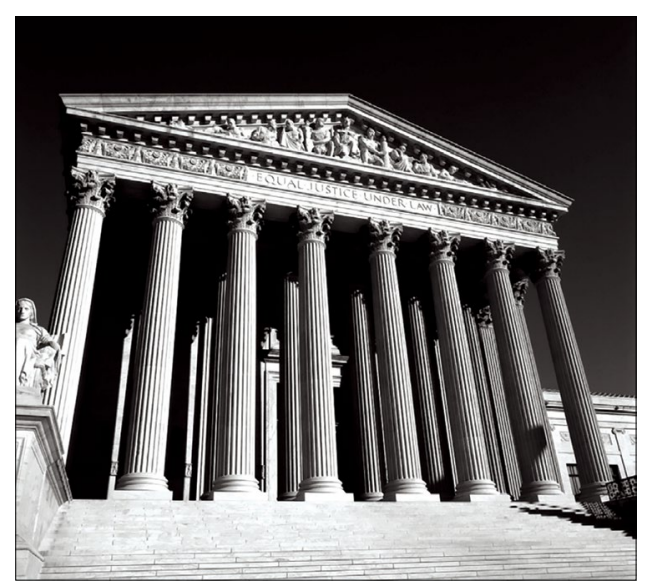

RĪGA • 2016 • RSU 
Socrates: Rīgas Stradiṇa universitātes Juridiskās fakultātes elektroniskais juridisko zinātnisko rakstu žurnāls = Rīga Stradiņš University Faculty of Law Electronic Scientific Journal of Law. Rīga, RSU, 2016, Nr. 1 (4). 113. lpp.

\section{Redkolēgija / Editorial Board}

Jānis Gardovskis (vadītājs) - Dr. habil. med. profesors, Rīgas Stradiṇa universitāte, Latvija Iveta Ozolanta - Dr. habil. med. profesore, Rīgas Stradiṇa universitāte, Latvija Andrejs Vilks (atb. zin. redaktors) - Dr. iur. profesors, Rīgas Stradiṇa universitāte, Latvija Vladimirs Eminovs, Dr. habil. iur. profesors, Maskavas Valsts juridiskā universitāte, Krievija Osvalds Joksts - Dr. habil. iur. profesors, Rīgas Stradina universitāte, Latvija Viktors Justickis - Dr. habil. iur. profesors, Viḷnas Mīkola Romera universitāte, Lietuva Sandra Kaija - Dr. iur. profesore, Rīgas Stradiña universitāte, Latvija Valters Kego (Walter Kego) - Zviedrijas Drošības un politikas attīstības institūts Ando Leps - Dr. habil. iur. profesors, Tallinas universitāte Nord, Igaunija Jaceks Zeḷinskis (Jacek Zielinski) - Dr. habil. sc. pol. profesors, Polijas Administrācijas augstākā skola Alvīds Šakočs (Alvydas Šakočius) - Dr. iur. profesors, Lietuvas Militārā akadēmija, Lietuva Vitolds Zahars - Dr. iur. profesors, Daugavpils Universitāte, Latvija

Redakcijas padome / Editorial Council (Rīgas Stradina universitāte)

Jānis Baumanis - Dr. iur. vadošais pētnieks

Jānis Grasis - Dr. iur. asoc. profesors

Osvalds Joksts - Dr. habil. iur. profesors

Aldis Lieljuksis - Dr. iur. asoc. profesors

Sandra Kaija - Dr. iur. profesore

Uldis Kinis - Dr. iur. asoc. profesors

Andrejs Vilks - Dr. iur. profesors

Tenis Nigulis - Izdevniecības un poligrāfijas daḷas vadītājs

Visi žurnāāa ievietotie raksti ir recenzēti. / All journal articles are reviewed.

Citējot atsauce uz izdevumu ir obligāta. / Upon citing the journal article, reference to the journal is mandatory.

Autoru viedoklis var nesaskanēt ar redkolēgijas viedokli. / Opinion of authors may not coincide with editorial views.

Par faktu pareizibu atbild autori. / The authors are held responsible for the truthfulness of the facts.

Redaktores / Editors: Indra Orleja, Aija Lapsa (latviešu val.), Regīna Jozauska (anglu val.)

Maketētāja / Layout: Ilze Reitere

RSU IPD Nr. 16-091

(C) Rīgas Stradiṇa universitāte, 2016

Dzirciema iela 16, Rīga, LV-1007 


\section{Saturs / Contents}

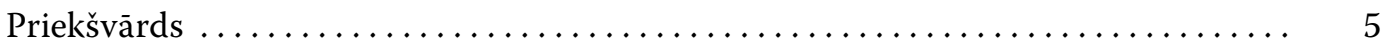

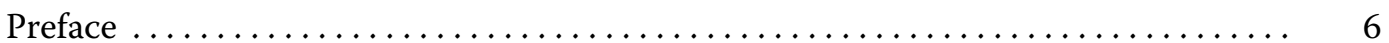

Jacek Zieliński. Legal Policy of the European Union in the Sphere of Migration and the Significance of Its Citizens' Security Sense for the Future $\ldots \ldots \ldots \ldots \ldots \ldots \ldots \ldots \ldots \ldots \ldots \ldots \ldots \ldots, 7$

Eiropas Savienības tiesiskā politika migrācijas jomā un tās nozīme iedzīvotāju drošības sajūtas par nākotni nodrošināšanā (Kopsavilkums) . ...... 12

Marina Sumbarova.The Value of Fixation Method of Material Traces in the Criminal Procedure for the Investigation of Crimes $\ldots \ldots \ldots \ldots \ldots \ldots$ Materiālo pēdu fiksācijas metodes nozīme kriminālprocesā noziegumu izmeklēšanai (Kopsavilkums) $\ldots \ldots \ldots \ldots \ldots \ldots \ldots \ldots \ldots \ldots \ldots . \ldots \ldots$

David Gaft. Prediction Model for Probability of Terrorist Activities in the Western World

Iespējamo teroristisko darbïbu prognozējamais modelis Rietumvalstīs

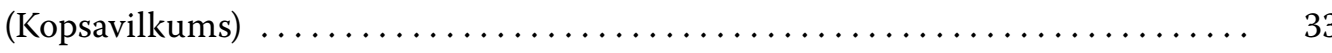

Andrejs Vilks. Nelegālā migrācija drošības nodrošināšanas kontekstā $\ldots \ldots \ldots \ldots . . \ldots 36$

Illegal Migration in the Context of Ensuring the Security (Abstract) ......... 43

Ëriks Treḷs. Teksta juridiskās ekspertīzes īpatnības lietās par naida

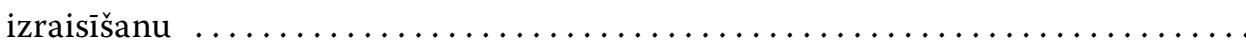

Legal Expertise Features of the Text in Cases of Hatred Triggering

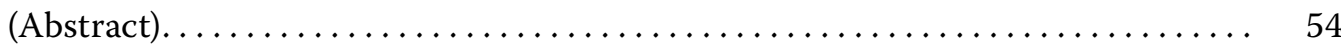

Aleksandrs Matvejevs. Policijas darbinieku izglitīibas problēmas Latvijā $\ldots . . \ldots \ldots \quad 57$

Problems in Education of Police Officers in Latvia (Abstract) ............ 62

Jeḷena Alfejeva. Nelikumīgas darbïbas iespējamie riski Latvijas

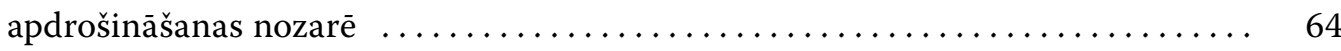

Possible Risks of Illegal Activities in Latvian Insurance Sector (Abstract)....... 74 
Juris Stukāns. Tiesību pārsūdzēt lēmumu realizācijas problemātika procesā

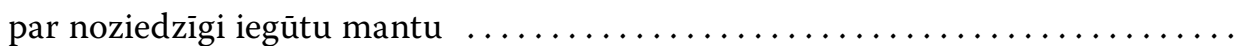

Issues Related to the Rights to Appeal in Proceedings Regarding

Criminally Acquired Property (Abstract) ....................... 84

Jānis Baumanis. Atkarības jēdziena interpretācija krimināltiesībās $\ldots \ldots \ldots \ldots \ldots \quad 86$ Interpretation of the Concept of "Dependency" in Criminal Law

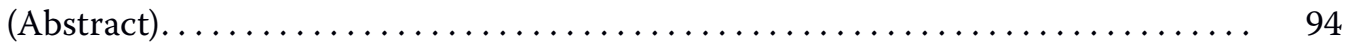

Svetlana Sitnikova. "Tiesību tikt aizmirstam" piemērošanas un izpratnes problēmas Latvijā ....................................... 96

Application and Understanding Problems of the "Right to be Forgotten"

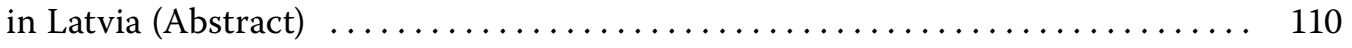

Autoru alfabētiskais rādītājs / Alphabetic List of Authors ................ 113 


\section{Priekšvārds}

Katrs gads, mēnesis un pat diena nes jaunus notikumus, izpausmes, kas ikvienu var ietekmēt emocionāli, radīt pārmaiṇas sadzīvē un saistās ar situāciju un dzīves apstākḷu izvērtējumu. Mūsdienās, pieaugot nelegālajai migrācijai, paplašinoties terorisma draudiem, palielinoties sociālajai spriedzei, saasinās problēmas, kuras ir saistītas ar drošības nostiprināšanu. Pieaug ekstrēmisma un radikālisma draudu iespēja. Minētās problēmas, kuras spilgtāk ir vērojamas Ziemel̦āfrikā, Rietumeiropā un citos reǵionos, tomēr neizbēgami ir attiecināmas arī uz Latviju. Teroristiskie akti Parīzē, nāvinieku džihādistu spridzināšana Briselē atbalsojas uz cilvēkdrošību individuālajā un sabiedriskajā apzin̄ā. Drošỉbas nostiprināšanai ir dažādi līmeṇi un mērogi. Neapšaubāmi, mēs apzināmies drošības globālās kontūras, mūs ietekmē drošỉba transnacionālā un regionālā līmenī. Vēl būtiskāka ir drošības nozīme nacionālā - Latvijas - ietvarā un ikviena cilvēka dzīvē.

Rīgas Stradiṇa universitātes Juridiskā fakultāte sadarbībā ar Juridisko koledžu un Tallinas augstskolu Nord, kā arī Zviedrijas Drošības un politikas attīstības institūtu 2016. gada 20. aprīlī organizēja starptautisku konferenci "Mūsdienu sabiedrības jaunie izaicinājumi drošîbas nostiprināšanā: reālais stāvoklis un perspektīvas". Tajā piedalijjās speciālisti un eksperti drošîbas un noziedzības novēršanas un apkarošanas jautājumos no Gruzijas, Igaunijas, Izraēlas, Lietuvas, Polijas, Somijas, Ukrainas, Zviedrijas un Latvijas. Konferences gaitā tika apspriesti aktuāli drošỉbas nostiprināšanas jautājumi: jauni apdraudējuma veidi un jauni izaicinājumi to novēršanā; jaunās pieejas tiesiskajā politikā drošības nostiprināšanā pašreizējos apstākḷos; speciālās izmeklēšanas darbības un operatīvie pasākumi apdraudējumu diagnostikā, novēršanā, neitralizēšanā un atklāšanā; tiesību aizsardzības iestāžu un speciālo dienestu darbības optimizācijas virzieni. Daži no konferencē sniegtajiem ziṇojumiem ir iekḷauti "Socrates" ceturtajā izdevumā, kā arī tiks publicēti nākamajos numuros.

Šajā "Socrates" izdevumā ir atspoguḷotas dažādas pieejas apdraudējumu apzināšanā un drošības nostiprināšanā. Interesants ir Jaceka Zeḷinska (Jacek Zieliński, Polija) raksts par Eiropas Savienības migrācijas politiku un iedzīvotāju drošību, kā arī Deivida Gafta (David Gaft, Izraēla) vēstījums par modeli, kas l̦auj prognozēt iespējamās teroristiskās darbības pasaulē, kurā mēs dzìvojam. Visi žurnālā ietvertie raksti var būt noderīgi drošỉbas dienestu speciālistiem, kā arī praktizējošiem un topošiem juristiem.

Rīgas Stradiṇa universitātes Juridiskās fakultātes dekāns profesors ANDREJS ViLKS 


\section{Preface}

Each year, and even each day brings new events or experiences, which may affect any person emotionally, cause changes in life, and call for the assessment of the situation and life conditions. Currently, with the increase of illegal migration, the expansion of threat of terrorism and social stress, the problems dealing with safety reinforcement are becoming acute. Threat of extremism and radicalism increases. The problems mentioned, so far most vividly being observed in North Africa, Western Europe and other regions, are inevitably attributable to Latvia as well. Terroristic acts in Paris, self-murder jihadist blasting in Brussels have echoed in each individual's and public consciousness in relation to human safety. Safety reinforcement is of different level and scale. No doubt, we are aware of global and mega-dimensions of safety, we are aware of safety at transnational and regional levels. The most essential is the importance of safety at the national level, i.e., in Latvia, and this concerns each person's life. The President of Latvia Raimonds Vejjonis has stressed, that "One of the greatest challenges of our century is safety. It is important to understand that safety implies a very broad spectre of issues, and almost any field of our people's lives".

On 29 April 2016 Rīga Stradiņš University, Faculty of Law, together with Legal College and Tallinn Higher School Nord, as well as Swedish Security and Policy Development Institute organised an international conference "The new challenges of modern society for safety reinforcement: realistic situation and perspectives". Specialists and experts on issues of safety and crime prevention from Georgia, Estonia, Israel, Lithuania, Poland, Finland, Ukraine, Sweden and Latvia took part. The conference dealt with topical and significant safety reinforcement issues: new types of threats and new challenges for their prevention; new approaches in legal policy of safety reinforcement in current conditions; special investigation actions and operational measures on threat diagnostics, prevention, neutralisation and detection: optimisation trends of activities to be undertaken by law enforcement institutions and special services in current situation. Some of conference presentations are available in "Socrates" fourth edition, and will be published in the fifth edition.

"Socrates" edition describes different approaches in hazard identification and safety reinforcement. Undoubtedly, an interesting article is written by Jacek Zielinski (Poland) on migration policy and the population safety in the European Union, and also the message of David Gaft (Israel) about prediction model of probable terroristic actions in the world in which we live. Articles, included in the journal "Socrates" No. 4 will be useful to professionals of special service, practising and would-be lawyers.

Professor ANDREJS ViLKs,

Dean of Faculty of Law, Rīga Stradiņš University 


\title{
Legal Policy of the European Union in the Sphere of Migration and the Significance of Its Citizens' Security Sense for the Future
}

\author{
Jacek Zieliński \\ Siedlce University of Natural Sciences and Humanities, \\ Social Sciences and Security Institute, Poland \\ uczelniajz@tlen.pl
}

\begin{abstract}
The necessity of the single migration- and terrorism-related legal policy development within the European Union is undisputed. It may turn out, however, that measures taken would not bring any improvement unless the priorities within such values as equality, respect for diversity, free movement of persons, solidarity and citizens' security are previously established, sometimes - with a new content. The Author takes the position that the values considered now to be the core of the EU existence and its key achievement can underpin its disintegration. The escalation of migration stimulates centrifugal destructive movements reflected in the increasing impact of the renationalisation philosophy of thinking about Europe on the Community solidarity, fossilisation of social moods and expectations, growing popularity of right-wing parties. All these, in consequence, foster the fossilisation and restrictiveness of law. It is related in part to the fear of globalisation and in part to the excessive regulations at the macro level, therefore to the breach of self-identification security that is getting more and more apparent nowadays.

From that perspective, the separation of the contradictions that have arisen between the basic EU values as regards providing single legal policy in the migration area seems to be cognitively valuable. Another issue is to answer the question how this wave of refugees has escalated and whose interest is currently in the destabilisation of Europe. The question is all the more important that the refugees are not heading towards other culturally closer Islamic countries or the USA but the pillar-states of the EU.

Keywords: migration policy, refugees, solidarity, fossilisation of societies, security of self-identification.
\end{abstract}


Jacek Zieliński. Legal Policy of the European Union in the Sphere of Migration and the Significance of Its Citizens' Security Sense for the Future

\section{Introduction}

Increasing processes of migration into Europe are a test for the European solidarity and cohesion as well as pragmatism of functioning of its structures." They have emphasised the need to find solutions that would avert the present situation and first of all would prevent the similar consequences in the long term. The problem was already recognised in November 2014, even before Jean Claude Juncker took up his duties as the President of the European Commission. It was considered one of the ten challenges of the contemporary Europe. Furthermore, it was included in the European Agenda on Migration of 13 May 2015, prepared as the response to European citizens' concern on the inefficient functioning of the European asylum law. [7] Two types of measures have been determined in the Agenda: current ones, related to the growing flood of migrants and long-term ones, designed to rectify the situation in the future. The latter is also discussed in this article.

The fact remains that the development of the common legal policy on migration has failed and there has been no single definition of terrorism to the present day. In consequence, having had numerous theoretical concepts, we also experience several approaches in reaction to the escalating migration process, starting from the Willkommenspolitik (welcome policy) [7] and ending with constructing border fences or migrants' forced detention. The essence of the matter seems not to be confined merely to the lack of legislation but to the lack of strategy that would be further reflected in the legal form. In order to fulfil its ordering and educational functions in a proper way, law ought to have a joint, transparent and socially accepted idea behind [12, 118-119]. The issue of migration belongs to the sphere of citizens' security, therefore their rights and obligations. It has its own normative as well as, first of all, a subjective dimension, including an individually taken sense of occurrence.

There is a large number of examples when a law made for the implementation of certain objectives, is used quite differently from legislators' intentions [17, 9]. In this context, the analysis of legal life should include formal and legal as well as non-legal (namely in a manner of law application) aspects. Therefore, it is not about the creation of further prohibitions or orders but whether they will be applied in the appropriate purpose of the common good $[8,430]$. That being the case, normative aspects of law as well as all other matters, normatively unnamed but directly connected with the overriding principles of each democratic country $[10,227]$ need to be analysed.

* In 2014, 276113 migrants entered Europe by sea, that means 138\% more than in 2013. Retrieved from: www. europa.eu. 
Jacek Zieliński. Legal Policy of the European Union in the Sphere of Migration and the Significance of Its Citizens' Security Sense for the Future

\section{On the essence of divagation}

Having appreciated the EU actions of organisational and structural nature that are necessary for normalising the present situation, as well as debates over the European migration policy, starting discussions on the broader issue - the vision of uniformity and solidarity background of the European Union as a guarantor of the common good and the safety of the national states and their citizens - seems to be of key significance. The migration processes have infringed the existing stability and highlighted latent distinctiveness and areas of tension. What is more, they have created the new ones. In that context, the migration processes have played a positive role, unless they would not contribute to the reflection on the stability-frozen or new areas of tension, and, in consequence, on the identity and position of the Union as well as its attitude towards the interests of the member states and current international situation. It is impossible to create efficiently functioning legislation without determining a value system out of the social context.

My guiding thesis is that the European Union, seeking the fulfilment of its fundamental values such as democracy, liberty, equality, solidarity, respect for diversity, free movement of persons, may lead to its own collapse. The values in themselves have become a threat for the UE security as a whole and for its individual member states.

It is a fact that there are ever more intensive voices in developing a common migration policy, precise separation between the status of a refugee and an emigrant and unambiguous definition of terrorism. Another fact is that the conservative migration policy combined with the economic attractiveness of Europe provides an impetus for the growth of refugee processes. Europe is not prepared, staying faithful to its fundamental values under solidarity policy, to ensure that its citizens have the right to benefit fully from them.

Revision of the existing priorities in the frame of such values and principles of the EU civilization standards as citizens' security, equality, solidarity, respect for diversity, free movement of persons, remains a major challenge. It is critical to find modus vivendi that would eliminate outlined contradictions between the values without abandoning them. This applies to all fields of state activity from political and military ones to social, cultural and custom-related. It may appear that some of them will have to be redefined in order to correspond not to inward-looking short-term necessity but to modern development processes [more: 11]. It is required for increasing erosion of social confidence in authorities who decide on the Union and states cohesion and therefore their security and legitimacy. Areas of tension are numerous although five of them deserve special attention. 
Jacek Zieliński. Legal Policy of the European Union in the Sphere of Migration and the Significance of Its Citizens' Security Sense for the Future

\section{Areas of tension}

Area No. 1. Domination of legal and institutional approach to democracy over modern social relationships, when its subjective aspect, consistent with a functional approach emphasising actions taken for a common good, is more important for societies. There is, however, no single common good and its perception depends on social, cultural, religious, historical and other factors. Thus, it is difficult to speak about one single democracy, because there is always some kind of democracy. This does not change, however, the validity of Giovanni Santori's statement: it could be considered anything." Actions taken in Afghanistan, Iraq, Libya, and, at present, in Syria, did not result in stabilisation of the situation. Moreover, they generated the escalation of security threat into the areas where it had occurred occasionally until then.

Area No. 2. Multicultural policy assuming creation of a society in which various cultures will assimilate, does not exist, in fact. In case of significant cultural, religious or social discrepancies, the process of bottom-up assimilation with the host country's culture does not take place. Separate islands are created instead, which act according to their own rights and rules [4,2]. Such ad hoc measures as creation of reservations or islands, adopted by states in the name of national interest protection, and therefore citizens' safety, merely staunched the situation also through the spirit of strengthening on a bottom-up basis ethnic, religious, etc. solidarity." The experience of such countries as Australia and the USA proves this.

However, the idea of sealing borders faces the allegation of pushing refugees away from potential shelters and acting contrary to the 1951 Geneva Convention Relating to the Status of Refugees as well as inhuman behaviour. Mainly German politicians Chancellor Angela Merkel and President Joachim Gauck argue for the need of receiving refugees. In spite of that, the Agreement of 28 January 2016 known as Asylpaket II was concluded. It concerns the limitations of migrants' residence on the territory of Germany. Two demands of migration opposition are included in the Agreement: opening of "hotspots" - reception centres where applications of people whose reception is less probable would be examined under an expedited procedure, and introduction of two-year restriction in the right to family reunification for people who do not meet the requirements for recognising refugee status within the meaning of the 1951 Geneva Convention, that is those who were not directly persecuted or came from the so-called safe third countries and were granted the right of residence in Germany on the basis of subsidiary protection [19].

* That does not mean that democracy is anything. More: Satori G. Teoria demokracji. Warszawa, 1998.

** Hungary closed their borders with Serbia and Croatia. Slovenia and Austria did the same. Norway introduced the regulation of turning back illegal emigrants from the territory of Russia. Singular states of the Schengen Area exercised their right to temporary restoration of border control. 
Jacek Zieliński. Legal Policy of the European Union in the Sphere of Migration and the Significance of Its Citizens' Security Sense for the Future

Area No. 3. Restrictive legal policy in terms of economic emigration under the label protection of the market versus idealistic policy for refugees with solidarity and aid values. The EU visa process involves meeting of certain requirements according to the country of origin. Getting a work permit is even more difficult. Obtaining such a visa is almost beyond the reach for citizens from many countries. The situation is similar in case of asylum process. On the other hand, group arrivals as a consequence of an escape from fragile countries is governed by the principle of solidarity and aid, or, recalling Angela Merkel's term, Leitkultur (guiding or leading culture). [5] Moreover, the more massive, the simpler, as it less controllable. Refugees receive social assistance and are not condemned to look for their place alone (at an early stage). Among the migrants, there are refugees and also economic emigrants or members of terrorist groups. It is estimated that $57 \%$ of refugees are men, that means people who intend to settle and apply for reuniting with their families in future. The European Union, due to the lack of coordination of its policies, nolens volens not only fosters the process of growing number of refugees, but also discredits public conviction of legitimacy of established values and principles. This is confirmed by polls conducted in Germany, the country named by a great number of immigrants as their final destination. In the survey carried out for the German daily newspaper "Bild" (22-25 January 2016) the governing coalition CDU/CSU received $32.5 \%$ of votes whereas anti-immigration AfD (Alternative für Deutchland - Alternative for Germany), established in February 2013, took third place with $13 \%$ score [20].

Area No. 4. Fulfilment of the constitutional role in terms of ensuring citizens' security versus migration policy (in the broad sense). Aside from a specific definition of safety, there is an issue of the lack of security system for the EU citizens from enjoying our rights and freedoms by migrants. The statement of Cologne mayor, Henriette Rieker, suggesting that women should adopt new models of behaviour helping them to avoid sexual attacks, may sound controversial [6].

Area No. 5. Excessive legal mega-regulations, including the EU parities, etc. where everyone seeks the safety of their self-identity. The growth of these phenomena is sometimes connected with the social misunderstanding of globalisation processes or with the ambiguities of the EU policy. The grassroots centrifugal movement is being formed, with its usual renationalisation of thinking about a state, Europe and the world. This influences the EU solidarity, fossilisation of social approaches and behaviour as well as rapid rise of right-wing ideologies, which, in consequence, will lead to the radicalisation of legislation and perhaps the domination of the individual over the common.

\section{Instead of conclusion}

There are numerous reasons for creation of the above tension areas. One may argue over social incomprehension of globalisation processes, fear of novelty, excessive legislation, growth of deciding for one another. It is undeniable, however, that the European 
Jacek Zielinski. Legal Policy of the European Union in the Sphere of Migration and the Significance of Its Citizens' Security Sense for the Future

Union is still unprepared to react to consequences of its own actions and that aggravates another problem which may contribute to its further weakness. In other words, a dangerous policy has been undertaken, the results of which are unpredictable. There is also no overall and consistent plan of protection from its consequences. The existing reaction to threats through institutional and legal measures, as well as multiplication of structures, seems to be even more destructive than integral element. Without the strategic, political vision of self-existence, that results in creation of the so called "second front" - unifying in objection. In comparison to other cultures, religions, customs, ways of solving problems, a question arises about the scope of common and distinct issues we are to accept within the frame of solidarity - how much of community should be in the Union and how much of diversity.

However, since there are some cracks in the unity of the EU, another question arises - whose interest is to violate the stability of Europe. The migration problem actually did not exist until the events in Afghanistan, Iraq, Libya and Syria. It appeared along with the attempt to export the EU model of perceiving reality. It was created as the result of our European strive to impose a definite or, at the same time, an indefinite cultural model. Islamic refugees do not choose richer Arab countries, those that seem to be in cultural, religious and linguistic terms natural destinations - they choose Europe. Countries like the USA and Australia are beyond their interest.

We could discuss the legislation and its content. The traditional approach to legal regimes $[1,13-17 ; 2,59-62 ; 9,147-148 ; 14,4-10 ; 16,100-109 ; 18,172-176]$ fosters only determination for normative basis of settling various issues of social relationships. It is limited, however, to formal and normative regularities that do not correspond to the social ones. Legal regime, is not only regulated by legislation, but, first of all, it is regulated by the way how they operate. This decides about the position in which the state strives to the balance of various interests occurring in a society and determines and subordinates other values [11,17-18]. To make this happen, however, a thrust is necessary.

\section{Eiropas Savienības tiesiskā politika migrācijas jomā un tās nozīme iedzīvotāju drošības sajūtas par nākotni nodrošināšanā}

\section{Kopsavilkums}

Vienotas ar migrāciju un terorismu saistītas tiesiskās politikas nepieciešamība Eiropas Savienībā ir neapstrīdama. Tomēr var izrādīties, ka veiktie pasākumi neradīs nekādu uzlabojumu, ja vien kā prioritātes netiks izvirzìtas tādas vērtības kā vienlīdzība, cieņa pret dažādību, personu brīva pārvietošanās, solidaritāte un iedzīvotāju drošỉba, kas jau ir paredzētas, dažreiz - ar jaunu saturu. 
Jacek Zielinski. Legal Policy of the European Union in the Sphere of Migration and the Significance of Its Citizens' Security Sense for the Future

Autors pauž nostāju, ka vērtības, kas šobrīd ir ES pastāvēšanas kodols un tās galvenais sasniegums, var veicināt tās sabrukumu. Migrācijas eskalācija stimulē destruktĩvas centrbēdzes kustības, kas atspoguḷojas pieaugošā ietekmē uz renacionalizācijas filozofiju, domājot par Eiropas Kopienas solidaritāti, sociālo noskaṇu un vēlmju fosilizāciju, labējo partiju pieaugošo popularitāti. Tas viss var veicināt likuma fosilizāciju un modifikāciju, turklāt tas dạ̣ēji ir saistīts ar bailēm no globalizācijas un ar pārmērīgajiem noteikumiem makrolīmenī, līdz ar to pārkāpjot pašidentifikācijas drošību. No šì viedokḷa raugoties, pretrunu, kas radušās starp galvenajām ES pamatvērtībām un attiecībā uz vienotu tiesisku politiku migrācijas jomā, nodalīšana ir neapstrīdami nepieciešama. Vēl viens jautājums, kas prasa atbildi, ir: kādēẹ šis bēgḷu vilnis ir eskalējies un kā interesēs pašlaik notiek destabilizācija Eiropā? Un kāpēc bēg̣̣i nedodas uz citām kultūras ziṇā tuvākām islāma valstīm vai ASV, bet gan tieši uz Eiropu?

Atslēgvārdi: migrācijas politika, bēgḷi, solidaritāte, sabiedrības fosilizācija, pašidentifikācijas drošîba.

\section{References}

1. Beliaeva, G. S. Pravovoi rezhim: problema opredeleniia poniatiia i ustanovleniia priznakov. Vestnik Vladimirskogo iuridicheskogo instituta. 2012, 1. (Бемяева, Г. С. Правовой режим: проблема определения понятия и установмения признаков. Вестник Владимирского юридического института. 2012, 1.)

2. Black, D. The Behavior of Law. New York: Academic Press, 1976, 2.

3. Cotterell, R. The Sociology of Law. London: Butterworths, 1984.

4. Die Zeit, online, 06.10.2010 [04.03.2016.].

5. Dobrowolska-Polak, J. Kryzys imigracyjny - Europa w oku cyklonu. Biuletyn Instytutu Zachodniego, 219/2016. Retrieved from: www.iz.poznan.pl [04.03.2016.].

6. European Agenda on Migration. Retrieved from: www.eu.europa.eu [04.03.2016.].

7. Lempert, R. \& Sanders J. An Invitation to Law and Social Science. Philadelphia: University of Pennsylvania Press, 1986.

8. Luhmann, N. A Sociological Theory of Law. London: Routledge, 1985.

9. Matuzov, N. I., Malko, A. V. Pravovye rezhimy: Voprosy teorii i praktiki. Pravovedenie. 1996, 1. (Матузов, Н. И., Малько, А. В. Правовые режимы: Вопросы теории и практики. Правоведение. 1996, 1.)

10. Pałecki, K. Prawoznawstwo. Zarys wykładu. Prawo w porzadku społecznym. Warszawa, 2003.

11. Papastergiadis, N. The Turbulence of Migration. Cambridge: Polity Press, 2000.

12. Politik. Aerger in der Koalition: Altmaier will Asylpaket II so lassen. Der Spiegel. Retrieved from: http://www.spiegel.de/politik/deutschland/fluechtlinge-streit-ueber-asylpaket-ii-sollschnell-geklaert-werden-a-1076129.html [08.02.2016.].

13. Paprygin, E. S. Poniatie i sushchnost osobykh pravovykh rezhimov. Istoriia gosudarstva i prava. 2008, 16. (Папрыгин, Е. С. Понятие и сущность особых правовых режимов. История государства и права. 2008, 16.) 
Jacek Zielinski. Legal Policy of the European Union in the Sphere of Migration and the Significance of Its Citizens' Security Sense for the Future

14. Rubchenko, S. O. Pravovai rezhim: poniatie i priznaki. Vektor nauki Toliatinskogo gosudarstvennogo universiteta. Seriia: Iuridicheskie nauki. 2010, 2. (Рубченко, С. О. Правовой режим: понятие и признаки. Вектор науки Тольяттинского государственного университета. Серия: Юридические науки. 2010, 2.)

15. Sartori, G. Teoria demokracji. Warszawa, 1998.

16. Shanin, A. A. Pravovoi rezhim v strukture rezhima politicheskogo. Aktualnye problemy Rossiiskogo prava. 2009, 3. (Шанин, А. А. Правовой режим в структуре режима политического. Актуальные проблемы Российского права. 2009, 3).

17. Shepelev, A. N. Poniatie pravovogo rezhima i ego sviaz s iuridicheskim iazykom. Vestnik Tambovskogo universiteta. Seriia: Gumanitarnie nauki. 2014, 1. (Шепемев, А. Н. Понятие правового режима и его связь с юриАическим языком. Вестник Тамбовского университета. Серия: Гуманитарные науки. 2014, 1.)

18. Sitnikov A. P. Teoretiko-metodologicheskie podkhody k ponimaniiu kategorii "pravovai rezhim”. Izvestiia vysshikh uchebnikh zavedenii. Uralskii region. 2009, 1. (Ситников, А. П. Теоретико-методологические подходы к пониманию категории «правовой режим». Известия высших учебных заведений. Уральский регион. 2009, 1.)

19. Staszewski, M. T. (red.) Referendum Konstytucyjne w Polsce. Warszawa, 1997.

20. www.bild.de [03.03.2016.]. 


\title{
The Value of Fixation Method of Material Traces in the Criminal Procedure for Investigation of Crimes
}

\author{
Marina Sumbarova \\ The Baltic International Academy, Latvia \\ sumbarova.marina@inbox.lv
}

\section{Abstract}

In the research, the provisions are examined, concerning investigative activity in the criminal procedure, related to the description of material traces. The attention is paid to the material, which is recorded in the protocol of investigative action in the criminal procedure as evidences. The criminalistics value of trace evidence for the clarification of circumstances of the investigated crime is emphasised: its mechanism and its characteristic causal relations, a criminal and crime tools he used. Different kinds of problems are solved by the investigation of traces: identification, diagnostic, situational, etc.

For the qualitative investigation of crime, description of traces in the record of investigation is of great importance.

In accordance with the Part 1 of the Article 325 of Latvia Criminal Procedure Law, the course of the pre-process of investigative action and cases specified by law - also the course of other procedural action is recorded in the minutes of this action. For example, such a protocol in the criminal procedure is a protocol of inspection.

Investigative inspection as an independent investigative action represents the direct detection and investigation by the crime investigator objects relevant to the criminal case, their characteristics, properties, states and relative position. In the course of it, the major part of the traces of crime and a criminal, as well as other material evidences of paramount importance are detected and investigated.

In the research, the concept of material trace is determined. A material trace can be any change on the scene of accident, caused by the event of crime; the lack of similar changes, although, based on the mechanism of the committed crime they should be (negative circumstances). 
The author carried out the analysis of scientific literature, as well as expert practice that allowed representing the main data, which is necessary in describing the material traces in the record of the investigative action.

The description of the material traces must comply with such principles as com-pleteness, accuracy, clarity, clearness, use of the appropriate terminology, estimates and judgments.

Keywords: forensic science, view of place of occurrence, investigative actions, trace, criminal procedure.

\section{Aim}

The aim is the research of provisions specified in the protocol of the investigative activity in the criminal procedure, concerning the description of material traces.

The objectives of the research are the determination of characteristics of the protocol of the investigative activity in the criminal procedure and the value of material traces, described in the minutes of the investigative action as evidences.

\section{Method}

In the course of writing the article were used scientifically based methods, including dialectical method of cognition, comparative and legal, logical and legal, concrete and sociological.

The person, directing the process, investigator, prosecutor, judge (court) are implementing in the criminal procedure criminal and procedural proof which represents variety of cognition of reality.

The criminal and procedural cognition can be implemented strictly by the means of Latvia Criminal Procedure Law (hereinafter - CPL) [7]. To such means, refer investigative, judicial and other procedural methods of removing evidences.

In accordance with the Part 1 of the Article 325 of the CPL, the course of the pre-trial process of the investigative action and in cases specified by law - also the course of the other procedural actions are fixed in the minutes of this action. In the criminal procedure, it is the protocol of inspection. Investigative inspection as an independent investigative action represents direct detection and investigation of objects relevant to criminal case, their characteristics, properties, states and relative position. In the course of it, major part of traces of crime and a criminal are detected and investigated, as well as the material evidences of paramount importance removed.

Inspection of a crime scene in the criminal procedure is an urgent investigative action, which in accordance with the Part 1 of the Article 162 of the CPL provides for the inspection of a specific place and the objects located therein if it is carried out after obtaining the information on a committed criminal action and if there is sufficient grounds to believe that a criminal action has taken place or is continuing to take place in the location. 
Timely and qualitative inspection of a crime scene can provide the investigator with important actual data concerning all circumstances, included proof $[1,380]$. In addition, information obtained during the inspection will help verify various versions in order to mark the ways of their inspection, determine the scope of persons among which to search criminals and finally to solve the crime and prove the guilt of the offender.

In accordance with the Part 3 of the Article 162 of CPL, in the course of investigation of the crime scene, the person, directing the process, investigator can remove objects, bearing the traces of criminal action and documents. Objects and documents circulation of which is forbidden by law are removed, regardless of their connection with specific criminal procedure.

Removal of objects and documents is an integral part of the inspection of a crime scene.

Modern forensic science, based on norms of criminal procedure law has developed specific recommendations on order and rules in removing of traces, which can be recognised as material evidences. The main stages in the work with traces are detection of traces, their fixing, removing, saving, and investigation. These stages, as well as methods and tools of work with traces should be described in records of investigative actions. Besides, in the record it is necessary to precisely describe the results of this work - the place of detection of the trace, its size, appearance, etc.

Criminalistics value of traces is determined by the possibility of establishing the important circumstances of the investigate crime: its mechanism and characteristic of causal connections of it, criminal and criminal tools he used.

As professor A. Kavalieris defines, it is necessary to consider the prospects of the further improvement of implementation means of investigative actions. This development occurs in three main directions: development and introduction of means, which provide an opportunity to find, fix and use new types of traces in the investigation of crimes; development and introduction of scientific and technological means, which facilitate and increase the efficiency of search and fixing of traditional traces at the scene of accident; carrying out measures allowing during the inspection of a crime scene or immediately after it to carry out express research of the found traces and materials $[5,36]$.

Different types of problems are solved by the investigation of traces: identification, diagnostic, situational and others. The concept of a material trace is define as a material trace that can be any changes at the scene of accident, caused by event of crime; the lack of similar changes, although based on the mechanism of committed crime they should be.

The person, directing the process, as a rule, investigator, making up a protocol of inspection of a crime scene, records not only that fits his idea of what has happened, but also all information should be fixed, although at the first sight it can contradict the set leads at the initial stage of the investigation.

All facts and circumstances stated in the inspection, which can be of importance in the investigation are fixed in the state in which they have been at the time of inspection. Before the inspection or in the course of inspection, having obtained the information on 
changing of the object at the scene of accident, for example, if the eyewitness has changed the location of a corpse, a pose, then the person, carrying out the examination does not pay attention to this circumstance, and in the protocol fixes those circumstances which he has seen himself. The change of the object at the scene of accident is questioned and fixed in the course of other investigative actions: interrogation, investigative experiment, examinations $[4,10]$.

Professor A. F. Volynsky determines that the different types of problems are solved by the investigation of traces, including identification, diagnostic, situational and others $[9,186]$.

In order to fulfil the procedural requirements set out in the law, the protocol should include description of all actions of the investigator, as well as everything that is discovered during the examination in the same sequence, as the examination has been carried out and in the same form in which the discovered has been observed at the time of examination $[3,18]$.

Undoubtedly, the description of traces in the protocol should proceed with their removal. In the criminal and procedural literature, there are different opinions of scientists about the various substances found at the scene of crime as the supplement to the criminal evidence. It depends, first of all, on their connection with the investigated criminal act. Not frequently, the type of substance can be determined only after its investigation in the laboratory $[6,28]$.

In the description of the material traces in the protocol of the investigative action it is necessary to specify the main circumstances and conditions of detection of traces, data about object-trace carrier and data about the trace itself.

In some aspects of above-mentioned provisions, associated with these circumstances is important to emphasise the conditions they are found, for example, any terrains or enclosed spaces. Besides, it is important to fix what the environmental conditions were, for example, rain, snow, etc. Regarding the second provision mentioned above - objecttrace carrier - in the protocol, the accurate location of a particular object on which the material evidence was found should be specified, as well as the name of this object. As for the third provision associated with the data on the trace itself, it seems advisable to emphasise the circumstance: where exactly the trace was found. In this case, a number of scientists identify the conditions, which are important to specify in the protocol of inspection, for example, when this trace can be located by two fixed points. Material traces should be precisely recorded.

In her practice, the author in investigating criminal cases which have the investigator in the proceeding often paid attention to the drawbacks of procedural implementation in the protocols of inspection of a crime scene. Thus, in a criminal case on the theft of a car, the investigator described in the protocol of inspection the place of location of the car before its theft basing on the marks left by wheels in snow and indicated places of detection of wheel traces near a snow heap, although approximately 30 metres from this place, in the street, there was a residential house but the investigator did not 
record it. A month later, after the inspection of the criminal case, the citizen R. was suspected of committing a theft. During the investigative action - the verification of testimonies on the scene (by that time the weather conditions have changed and the snow melted away) - the suspect R. pointed to the house in the street and the approximate location of the car which he had stolen. The investigator had to interrogate the participants of the previous inspection, including the investigator, who held the inspection in order to determine the location of the car. Only in this way, it was possible to determine the place, where the car was stolen.

In studying criminal cases of thefts from apartments, the investigator often describes the removal of traces from various surfaces; however, it is important to specify on what surface the trace was found and from what place it was removed. Thus, in criminal case of theft from the apartment of the female citizen D., during the inspection fingerprints were removed from the jewellery box. During the inspection, the investigator has not recorded in the minutes the particular location of the removed trace. The acquaintance of the aggrieved party, female citizen $\mathrm{K}$. suspected of the theft of gold jewelleries from the apartment of the female citizen $\mathrm{D}$., during the pre-trial process testified that she moved the jewellery box from one place to another to clear the place for the coffee ware on the table. Thus the fingerprints could have remained on the jewellery box. Further on the criminal case, the expert and investigator were interrogated, who were involved in the inspection of this apartment, but they did not remember the specific location of removed fingerprints (on the external or internal surface of the jewellery box). Thus, the lack of accurate fixing of detected trace during the inspection did not provide an opportunity to the person, directing the process to prove the guilt of the female citizen $\mathrm{K}$. of the theft. The accuracy of indication of place of detection of trace is important for its further use as evidence.

Furthermore, the accuracy of the indication of place of detection of trace is necessary to see the prospect of its further use as evidence, taking into the consideration the circumstances, which can negatively influence the establishment of cause and effective relationships.

On a mandatory basis, the type and nature of package of removed traces are indicated in the record; safe closing, sealing for preventing the so-called unauthorised opening and supplied with explanatory inscription.

Thus, the description of material traces must comply with the following principles: legality, timeliness, completeness, accuracy, plainness, conformity to plan, use of appropriate terminology, objectivity, and modelling.

Let's consider the provisions, associated with the essence of some principles. The important condition of the description of traces in the record of investigative action is the completeness and accuracy of reflected information. This is a general requirement, concerning all evidences including the traces. The traces must be described in such way that the information about the actual picture of crime, criminal, aggrieved party, witness, circumstances, characterising the damage caused by the actions of criminal, 
as well as circumstances, characterising the method of commission of a crime and other circumstances which are to be proven; in future they could be used as the sources of evidences.

The principle of plainness of description of traces lies in the fact that the criminal procedure information recorded in the protocol should be clear to any participant concerning the place of detection, various characteristics of traces and their peculiarities, as well as the method of detection, fixing, removing and packaging.

The principle of appropriate terminology lies in the fact that in describing traces it is necessary to use scientific or generally accepted terms in the literature for the purpose of exclusion of misunderstandings and ambiguities.

One of the principles of inspection of the crime scene is the principle of modelling. The scientist A. I. Dvorkin defines the modelling as a recreation of a mechanism of the committed crime, expected actions of criminals and aggrieved parties, based on the initial accident scene, availability and localisation of available traces $[2,11]$.

However, in describing the material traces to full extent the observation of the above-mentioned principles are not always possible.

Sometimes investigators experience difficulties in establishing boundaries of description of the objects in procedural documents. These difficulties are associated with the inadmissibility of reflection in the records of investigative actions conclusions, assessments and judgments of investigator $[8,8]$.

Regarding the fixing of traces it is advisable to note that the person, directing the process should use certain expressions in describing traces, clearly describe objects and visible traces, related to the crime.

The article examined the main provisions, related to the methods of fixing of material traces. On the basis of the research, the criminalistics value of traces is determined by the establishment of different types of traces which are important evidences of the investigated crime associated with its disclosure, qualitative investigation and the rights of participants of criminal procedure and the human rights.

\section{Materiālo pēdu fiksācijas metodes nozīme kriminālprocesā noziegumu izmeklēšanai}

\section{Kopsavilkums}

Pētỉjumā tiek izskatīti nolikumi par materiālo pēdu aprakstu, kuri ir norādīti izmeklēšanas darbības protokolā kriminālprocesā. Tiek pievērsta uzmanība materiālām pēdām, kuras ir nofiksētas kā pierādījumi kriminālprocesā izmeklēšanas darbības protokolā. Ir 
uzsvērta pēdu kriminālistiskā nozīme nozieguma apstākḷu, mehānikas un tam raksturīgo sakaru, noziedznieka un tā izmantoto ieroču noskaidrošanai. Pēdu pētỉjums l̦auj atrisināt dažāda veida - identifikācijas, diagnostikas, situatīvus u. c. - uzdevumus.

Kvalitatīvā noziegumu izmeklēšanā pēdu aprakstam izmeklēšanas darbības protokolā ir svarīga nozīme.

Saskaṇā ar Kriminālprocesa likuma 325. panta 1. daḷu pirmstiesas procesā veiktās izmeklēšanas darbības gaitu, bet likumā noteiktajos gadījumos - arī citas procesuālās darbības gaitu, fiksē šis darbības protokolā. Šāds protokols, piemēram, ir apskates protokols.

Izmeklēšanas apskate kā patstāvīga izmeklēšanas darbība ir izmeklētāja veikta objektu, kuriem ir nozīme kriminālprocesā, pazīmju, raksturlielumu, stāvokḷa un vietas atrašana un izpētī̌sana. Apskates laikā tiek atrasta un izpētīta lielākā daḷa noziegumu un noziedznieka pēdu, kā arī citu materiālo liecību, kurām ir liela nozīme izmeklēšanā.

Pētījumā tiek noteikts materiālo pēdu jēdziens. Materiālās pēdas var būt: jebkuras nozieguma izraisìtas izmaiṇas notikuma vietas apstākḷos, šādu izmaiṇu trūkums, kaut gan, spriežot pēc nozieguma mehānisma, tiem būtu jābūt (negatīvi apstākḷi).

Autore veica likumu, zinātniskās literatūras un ekspertu prakses analīzi, kas l̦āva izdalīt pamatdatus, kurus vajadzētu atspoguḷot izmeklēšanas darbības protokolā materiālo pēdu aprakstes laikā.

Materiālo pēdu aprakstam ir jāatbilst tādiem principiem kā pilnīgums, precizitāte, skaidrība, attiecīgas terminologijias, vērtējumu un slēdzienu izmantošana.

Atslēgvārdi: kriminālistika, notikuma vietas apskate, izmeklēšanas darbības, pēdas, kriminālprocess.

\section{References}

1. Chegodaeva, S. S. Taktika sledstvennogo osmotra. Kriminalistika. Pod red. A. F. Volynskogo, V. P. Lavrova. 2-e izdanie, pererabot. i dopoln. Moskva: Zakon i pravo, 2008. (Чегодаева, С. С. Тактика следственного осмотра. Криминалистика. ПоА реА. А. Ф. Волынского и В. П. Ааврова. 2-е изА., переработ. и дополн. Москва: Закон и право, 2008.)

2. Dvorkin, A. I. Nekotorye obshchie polozheniia osmotra mesta proisshestviia. Taktika sledstvennykh deistvii (osmotr mesta proisshestviia i dopros): nauchno-metodicheskoe posobie. Pod red. A. I. Dvorkina, L. V. Bertovskogo. Moskva: Izdatelstvo "Ekzamen囚, 2011. (Аворкин, А. И. Некоторые общие положения осмотра места происшествия. Тактика слеАственных Аействий (осмотр места происшествия и Аопрос): научно-методическое пособие. ПоА реА. А. И. Аворкина, А. В. Бертовского. Москва: Издательство «Экзамен», 2011.)

3. Egorov, N. N. Sobiranie dokazatelstv v strukture procesa. Rossiiskii sledovatel. 2004, 3. (Егоров, Н. Н. Собирание Аоказательств в структуре процесса. Российский следователь. 2004, 3.)

4. Grieznis, P. Praktiskā kriminālistika: Izmeklēšanas darbības fiksācija, pēdu un lietiškso pierādījumu savākšana un izpēte. Otrā grāmata. Rīga: SIA "Petrovskis un Ko", 2009. 
Marina Sumbarova. The Value of Fixation Method of Material Traces in the Criminal Procedure for Investigation of Crimes

5. Kavalieris, A. Kriminālistiskā taktika. No: Kriminālistika. Otrā daḷa. Autoru grupa A. Kavaliera vadībā. Papildināts un paplašināts 4. izdevums. Rīga: Latvijas Policijas akadēmija, 2003.

6. Konovalovs, J. Vielas kā noziedzìga nodarījuma pēdas. Rīga, 2007.

7. Kriminālprocesa likums. 2005. gada 21. aprīlis, spēkā no 01.10.2005., ar grozījumiem no 02.12.2015. Latvijas Vēstnesis, 112 (4918).

8. Nesterov, N. I. Ustanovlenie gruppovoi prinadlezhnosti trasologicheskikh obektov. Volgograd, 1988. (Нестеров, Н. И. Установление групповой принадлежности трасологических объектов. ВомгограА, 1988.)

9. Volynskii, A. F. Kriminalisticheskoe issledovanie sledov prestuplenii. Kriminalistika. Pod red. A. F. Volynskogo, V. P. Lavrova. 2-e izdanie, pererabot. i dopoln. Moskva: Zakon i pravo, 2008. (Волынский, А. Ф. Криминалистическое исследование следов преступлений. Криминалистика. Под реА. А. Ф. Волынского, В. П. Ааврова. 2-е изАание, переработ. и Аополн. Москва: Закон и право, 2008.) 


\title{
Prediction Model for Probability of Terrorist Activities in the Western World
}

\author{
Dr. David Gaft \\ The State of Israel \\ davidgaft@gmail.com
}

\section{Abstract}

This article investigates global terrorism in general, with emphasis on Israel, suggesting suicide bombing attacks create a significant ripple effect considering the fact that although the actual number of attacks is relatively small, the number of people killed or wounded may account for as much as $50 \%$ of all casualties from terrorist activities.

One reason for this is the willingness of terrorists to commit suicide attacks and become "martyrs" rather than disappoint and betray their operators. Hence, the ability to deter activists is not a viable option. Prevention of terrorist attacks by suicide bomber cells may take place in a number of situations or events. In this work, we shall focus on the interception of suicide bomber terrorist cells attacks in three different phases: the early preparation phase, after one attack, and after several attacks.

Most administrative detentions are carried out during the early preparation phase, without use of force or risk of injury to friendly forces, such that many casualties are spared. In cases where the cell is not uncovered after the first attack, the chances of apprehending its members is greatly reduced and it is most likely the cell will not be caught until after it has carried out several attacks.

Keywords: terror, terrorist organisation, terrorists, Intifada, Hamas, punitive measures.

\section{Introduction}

Ever since its establishment, the State of Israel has been engaged in an ongoing struggle against terrorism [9]. As part of this uncompromising struggle, Israeli governments have been involved in countless military operations, intelligence activities and legal proceedings against various terrorists and terrorist organizations. However, the struggle against terrorism by a democratic country is very different from that of the individual [4]. 
In the second half of the 70s, and especially after the Iranian revolution, the involvement of Islamic movements in the Middle East conflict increased, an increase that is clearly visible in the West Bank, Gaza, and among Israeli Arabs. Palestinians saw the establishment of a radical religious movement that gave rise to militant groups that rejected all forms of political agreement.

Today there are several known methods for combatting suicide attacks:

1. Intelligence - effective intelligence allows forces to attack activists or their operators, who are regarded as a type of ticking bomb, and by doing so it is possible to thwart the attack [11].

2. Offensive operations - extensive operations against terrorist infrastructures are necessary for maintaining a continuous comprehensive initiative in order to preserve the achievements of such operations.

3. Punitive measures - although it is not possible to punish the bomber himself, the very knowledge that their family will be punished as a result of their actions serves as possible deterrence. Punishment is directed towards the suicide bomber's immediate family and is primarily executed when the bomber's family shows support for his attack.

Punishment is typically applied in one of two forms:

1) demolition of homes - Israel has carried out this punishment several times. Demolition is considered an especially effective means of discouragement and has proven itself effective in reducing the number of suicide bombing attacks;

2) deportation of the attacker's family members from the region.

4. Public relations - it is possible to encourage delegitimisation of suicide bombings by applying massive international pressure against the phenomenon, including recruitment of moderate voices from within the Arab and Muslim world who would speak out against the phenomenon and participate in establishment of a global consensus against suicide bombings.

Preparation of suicide bombers for Attack - by contrast to popular belief, suicide bombings are not sporadic acts of individuals who suddenly decide to act at their own initiative, but rather carefully planned operations that are driven by larger mechanisms that prepare the bomber for action. They are well-timed military operations in which the bomber himself is the final link in a long chain of command. Psychological and physical training of suicide bombers may extend for a long time. "Suicide bombers are no more than the tip of the iceberg of larger organisations" (Michigan War).

Since the end of 2001, when the number of Palestinian casualties in the second intifada greatly increased and living conditions in the Western Bank deteriorated, the pool of potential terrorist bombers dramatically increased and it was possible to send them out on missions following significantly shorter preparation period, with no more than minor psychological preparation. Even the psychological profile of suicide bombers is no longer as clear cut as it was prior to this time, with even married people, parents, and women carrying out attacks. [8] 
Aim. This paper focuses on the following stages: prevention of the activity of the terrorist group under preparation, interruption of its activity after the first attack, destruction after a terrorist campaign. The articles addresses the data about small terrorist cells and the incentives of their attacks. The theoretical model of a network of small terrorist groups and the nature of their activity have been analysed.

Material. The data about the terrorism in Israel formed the basis of the analysis. analysis.

Methods. Traditional, historical, sociological, anthropological, comparative

"Hybrid" terrorist organisations - that is, terrorist groups with semi-state, geographical, political, civil and institutional presence - pose special difficulties and challenges to those acting against them [5].

The several periods that were characterised by many terrorist attacks and political events that had direct impact on the region can be considered in the Table 1.

Table 1. Terrorist attacks and political events that had direct impact on the region

\begin{tabular}{|c|c|c|c|}
\hline No. & Period & Political Processes & Terrorist Attacks \\
\hline 1. & 1993-1997 & $\begin{array}{l}\text { Establishment of the Palestinian Authority. } \\
\text { The "Oslo A" agreements. } \\
\text { The "Oslo B" agreements. } \\
\text { Decrease in number of administrative detainees }\end{array}$ & $\begin{array}{l}\text { Multiple attacks by terrorist } \\
\text { squads and suicide } \\
\text { bombers. } \\
\text { High casualties }\end{array}$ \\
\hline 2. & $2000-2008$ & $\begin{array}{l}\text { Failure of government policy. } \\
\text { Policy of restraint. } \\
\text { The failure of Camp David Accords. } \\
\text { Unilateral withdrawal of the IDF from Lebanon. } \\
\text { Successful start in the war against. } \\
\text { Successful prevention of attacks. } \\
\text { From } 2002 \text { - over } 4000 \text { administrative detainees }\end{array}$ & $\begin{array}{l}\text { Wave of suicide bombing } \\
\text { attacks with large number } \\
\text { of casualties. } \\
\text { Decrease in number of } \\
\text { attacks only after } \\
\text { destruction of terrorist } \\
\text { cells in } 2005\end{array}$ \\
\hline 3. & 2013-2015 & $\begin{array}{l}\text { No negotiations. } \\
\text { Complete neutralisation. } \\
\text { Operation “Protective Edge" (Mivtza Tzuk Eitan). } \\
\text { Increased use of social networks }\end{array}$ & $\begin{array}{l}\text { Terrorist attacks by } \\
\text { individual operatives } \\
\text { (stabbings, running } \\
\text { over people, drive-by } \\
\text { shootings) }\end{array}$ \\
\hline
\end{tabular}

As seen in the table, there is one common denominator between the first and second periods: execution of attacks by terrorist cells and suicide bombers. By contrast, the third period is more characterised by individual operatives who were influenced by incitement on social networks [10].

The goal of suicide bombings, much like that of any other terrorist attack, is to achieve certain political objectives by violent means. 
Terrorist networks (Figure 1) are structured in a dispersed "clandestine cell" structure, with no definite military hierarchy [1], and often without any direct contact between the separate cells. Such a structure is very difficult for security forces to discover or prevent from carrying out their attack.

The arrows in the figure represent relationships between the different terrorist cells and their external environment: communication between cells, recruitment of new members, purchasing and manufacturing of weapons, movements in the field, and so forth.

Terrorist organisations design their networks such that there is integration of information between the different cells.

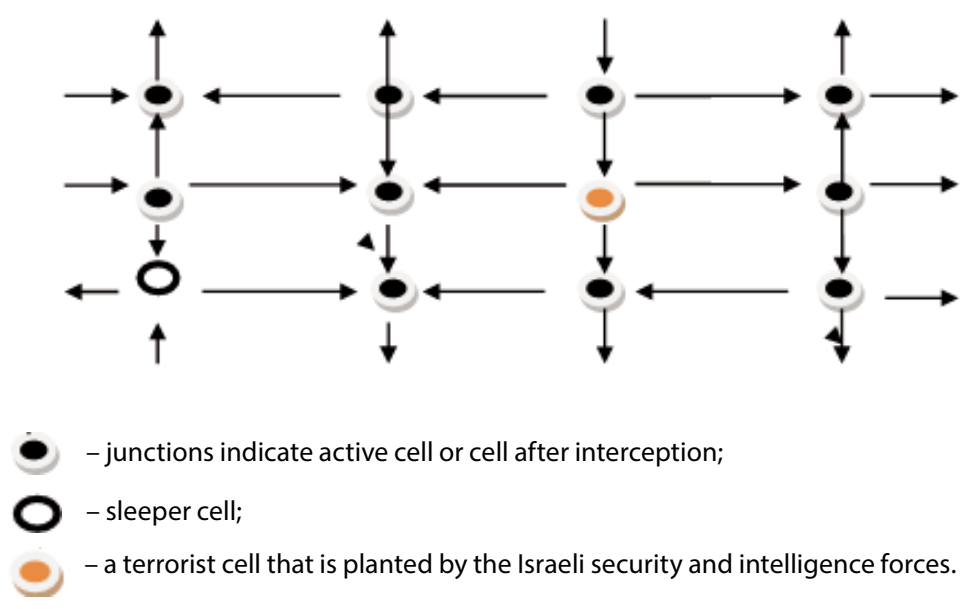

Figure 1. Illustration of a terrorist cell network

The intention is to ensure each cell is able to obtain the resources and information its members require in order to:

1) survive, and

2) initiate action or respond.

The structure of terrorist cells suggests an extreme ability to survive in an independent manner and sophistication of the integration processes (different types of communication) necessary for maintaining such independence. Terrorist cells establish an integration process as part of their existence and under their full responsibility (fast and dynamic changes in smaller organisations).

Consider a situation where one of the cells is exposed (the junction in the figure) or an intelligence cell is successfully "planted". Because of the links existing between the cells, other cells, which maintained contact with the exposed cell, are now "burnt". 
David Gaft. Prediction Model for Probability of Terrorist Activities in the Western World

For purposes of illustration only, in the terrorist network diagram we obtain the following:

$$
\mathrm{G}_{1}=\mathrm{n} \times \mathrm{T}
$$

where:

$\mathrm{G}_{1}$ - the number of terrorist cells that may be exposed as a result of exposing a neighbouring cell (See the Network diagram above);

$\mathrm{n}$ - the number of arrows pointing out of exposed cells towards other network cells;

$\mathrm{T}$ - exposed cell/s (junctions).

In the terrorist network diagram (for illustration purposes only):

$\mathrm{G}_{1}=4$

$\mathrm{T}=1$

$\mathrm{n}=4$ (the number of arrows pointing out from the single junction)

We shall now calculate the potential impact of one cell being discovered or exposed on other cells that do not maintain direct contact or activities with that cell. We shall examine the phenomenon by which the exposed cell disengages itself from the other network cells that are furthest away from it.

This phenomenon is expressed using the fading coefficient $\lambda_{\mathrm{i}}$ :

where:

$$
\lambda=1,3 / 4,1 / 2,1 / 4, \ldots
$$

i - indicates increasing "distance" from the exposed cell $(\mathrm{i}=1,2,3,4, \ldots)$.

We shall now calculate the total number of cells that could "burn" following exposure of a single cell:

$$
\mathrm{G}=\lambda_{1} \mathrm{n}_{1} \mathrm{~T}+\lambda_{2}\left(\mathrm{n}_{2}-1\right) \mathrm{T}+\lambda_{3}\left(\mathrm{n}_{3}-1\right) \mathrm{T}+\lambda_{4}\left(\mathrm{n}_{4}-1\right) \mathrm{T} \ldots,
$$

or the following equation is obtained:

$$
\mathrm{G}=\lambda_{\mathrm{i}} \mathrm{n}_{\mathrm{i}} \mathrm{T}+\sum_{2}^{\mathrm{i}} \lambda(\mathrm{n}-1)
$$

In the theoretical model, we investigated the effect of one cell being discovered on other cells within the network.

The network drawing and equations for calculation of impact on the entire terrorist network allows us to analyse relevant data for uncovering of terrorist cells [7].

In this study, we created a model of a terrorist network as an additional layer of an interactive map, with visual information that connects between themselves and geographic location (Figure 2). The geographical mapping system will function as a unified operational platform.

In this research we shall study the behavioural model of terrorist cells (in the drawing, the network is a junction). 
David Gaft. Prediction Model for Probability of Terrorist Activities in the Western World

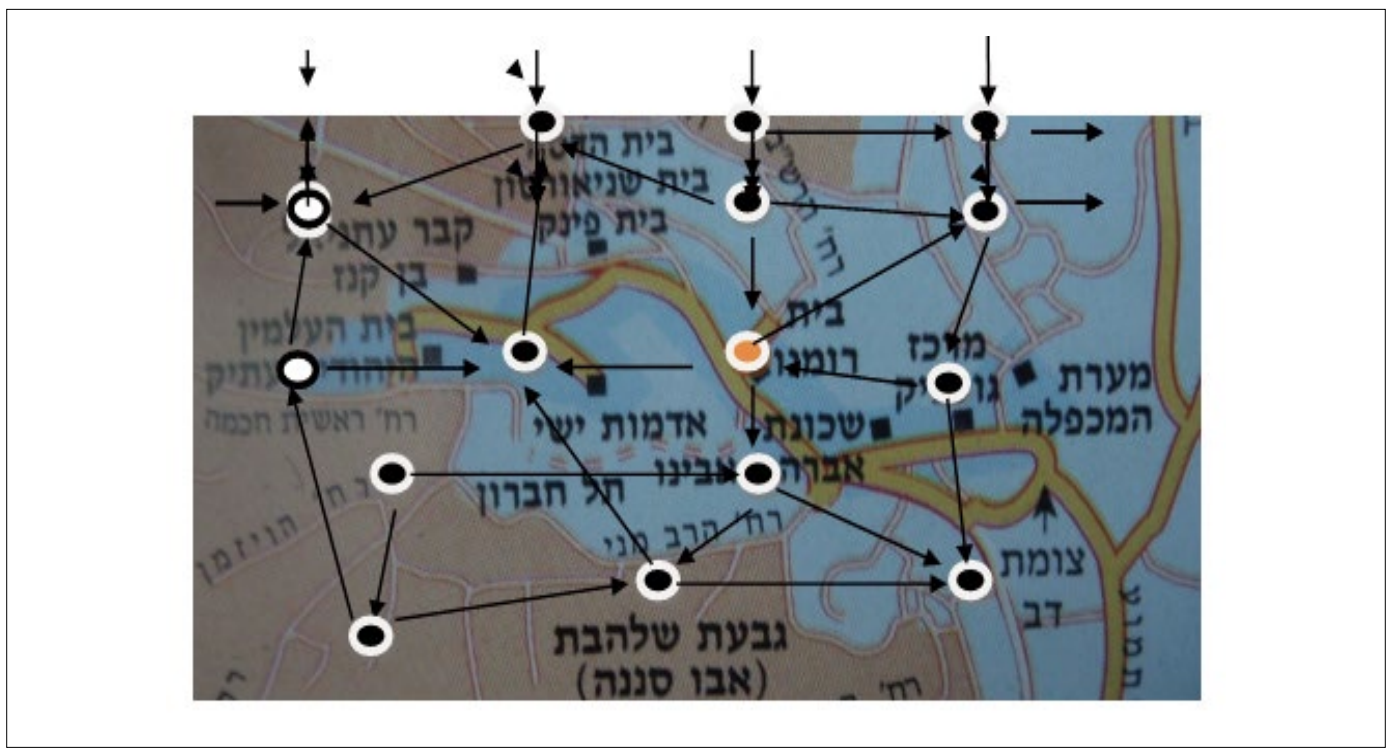

Figure 2. Illustration of a terrorist network platform on a map

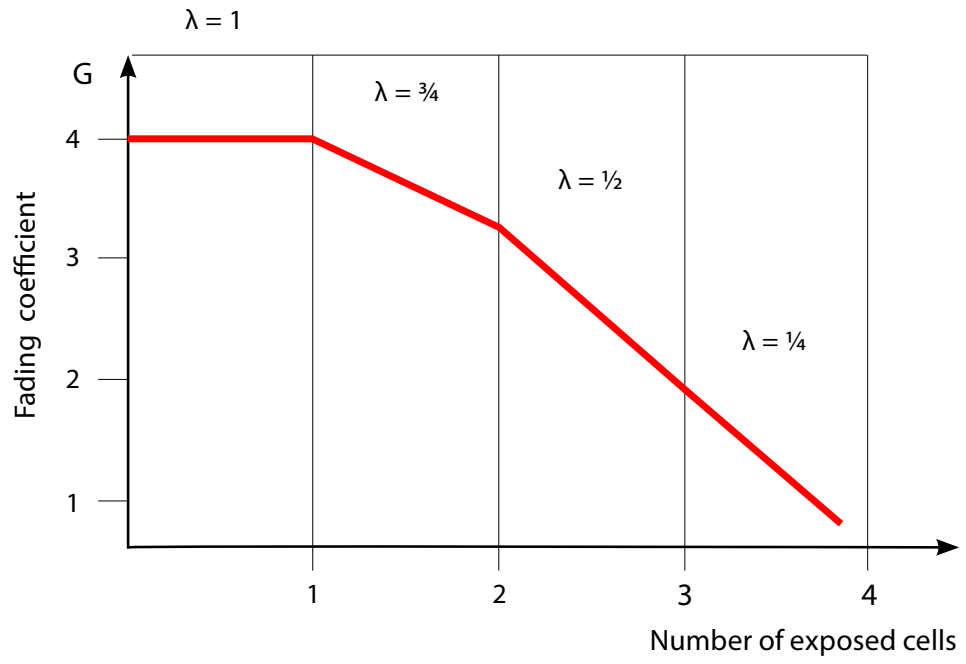

Figure 3. The decreasing probability for detection of terrorist cells 
David Gaft. Prediction Model for Probability of Terrorist Activities in the Western World

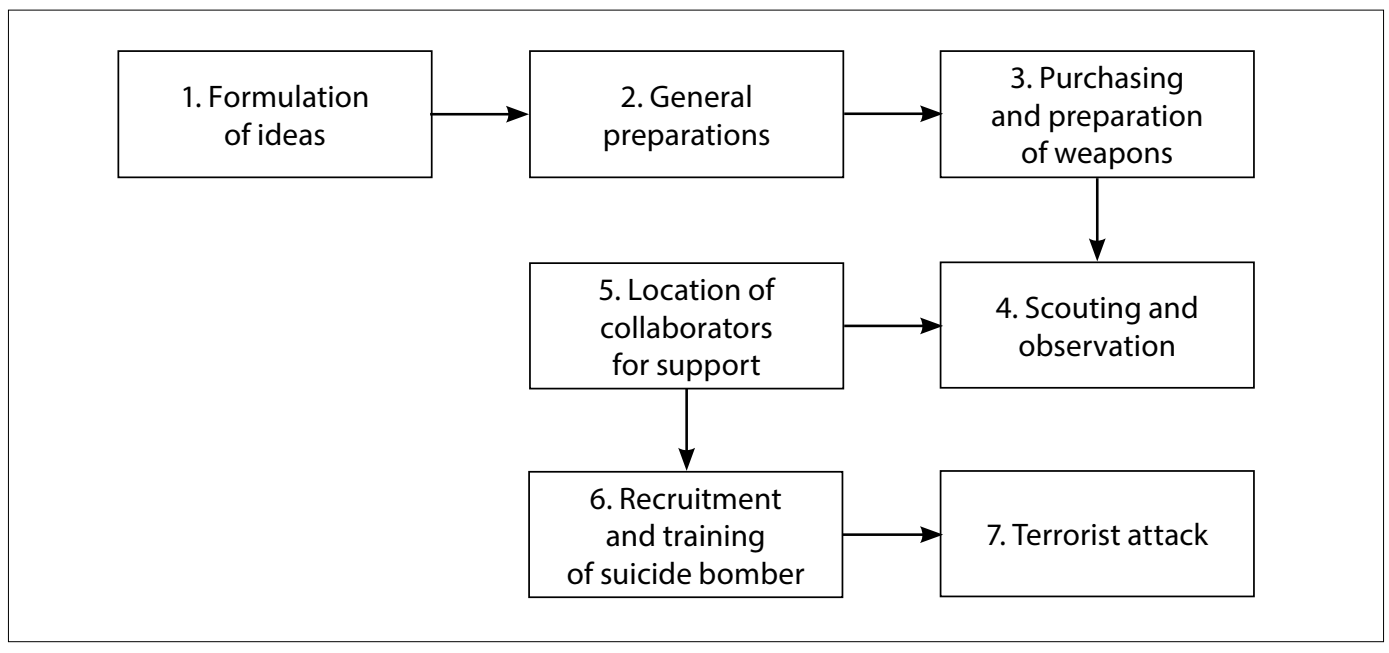

Figure 4. The activity of terrorist cells during establishment (including attack)

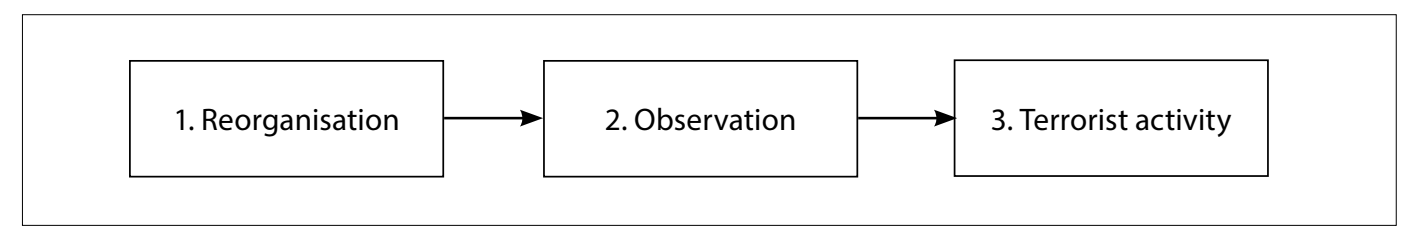

Figure 5. The stages in execution of a terrorist attack by a cell that was not discovered and remains operational

Total number of events:

where:

$$
\mathrm{N}=\mathrm{S}+\mathrm{P}
$$

$\mathrm{N}$ - total number of events;

$\mathrm{S}$ - number of interceptions during the measured period (several months, 1 year, several years);

P - total number of attacks during the period.

$$
P=1 x+2 x+3 x+4 x+5 x+6 x+7 x
$$

where:

$\mathrm{P}$ - a single terrorist attack including stages of exposure;

ix - stages of exposure.

Each stage represents a terrorist attack - potential for attack.

$$
\mathrm{P}=\sum_{1}^{7} x \quad \mathrm{P}=\sum p
$$


Statistical effectiveness coefficient $(F)$ for prevention of attacks - the Exposure Coefficient may be calculated using the following formula:

$$
\begin{gathered}
\mathrm{F}=\mathrm{S} / \mathrm{N} \\
\mathrm{F}=\mathrm{S} / \sum \sum{ }_{1}^{7} x+\mathrm{S}
\end{gathered}
$$

$F_{m}$ - statistical effectiveness - average rate of uncovering cells over 6-year period based on data presented in Figures 5 and 6.

$\mathrm{F}_{\mathrm{m}}=0.73$

According to the graph, the result suggest the following coefficients:

Example 1: Year $2005 \quad F=0.85$

Example 2: Year $2005 \quad \mathrm{~F}=0.875$

Example 3: Year $2005 \quad F=0.98$

The closer the number is to "1", the greater the effectiveness of security forces and their ability to destroy terrorist cells. Had the security forces failed to uncover cells or prevent attacks, the coefficient would have been close to "0". In this case the effectiveness statistical model is [3]:

$$
0 \leq \mathrm{F} \leq 1
$$

Examples for probability of exposure - prevention (data taken from Figures 1 and 2):

p2 - statistical value representing a cell that is not yet exposed, as per Figure 2.

$$
10 x+9 x+8 x=2 p
$$

Probability of exposing a single terrorist attack according to Figure 1:

$$
\mathrm{Y}=\sum_{1}^{7} x / \sum_{1}^{7} x+\sum_{8}^{10} x=0.7
$$

Probability of exposing a single terrorist attack according to Figure 2:

$$
\mathrm{Y} 2=\sum_{8}^{10} x / \sum_{1}^{7} x+\sum_{8}^{10} x=0.3
$$


David Gaft. Prediction Model for Probability of Terrorist Activities in the Western World

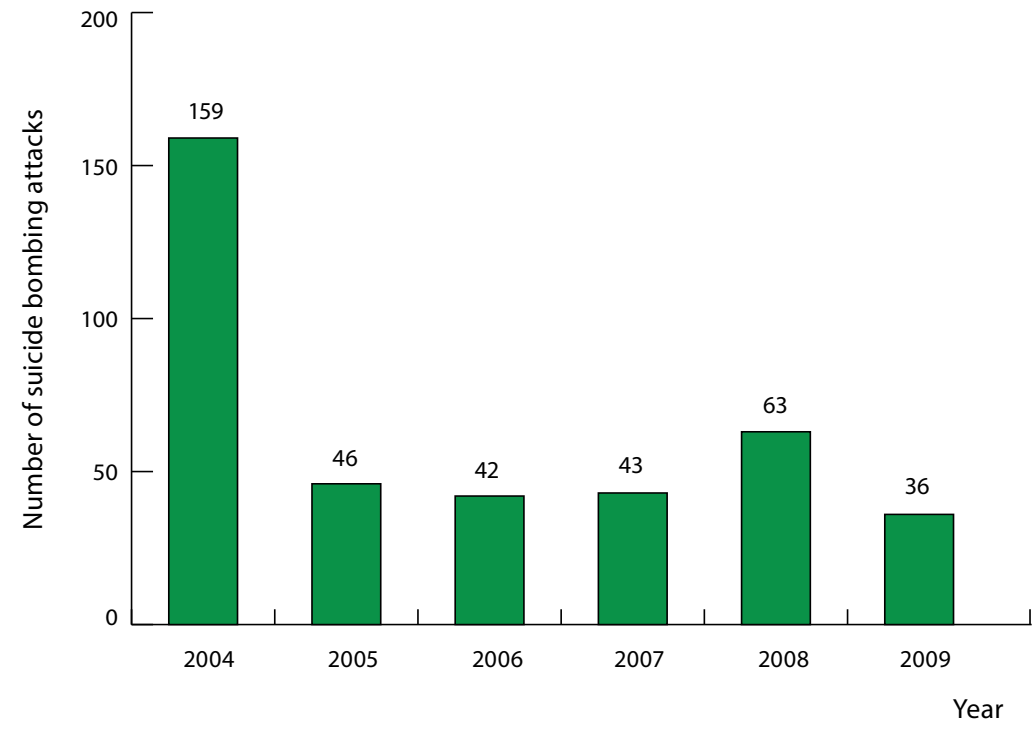

Figure 6. Number of suicide bombing attacks since the beginning of the conflict (sorted by years)

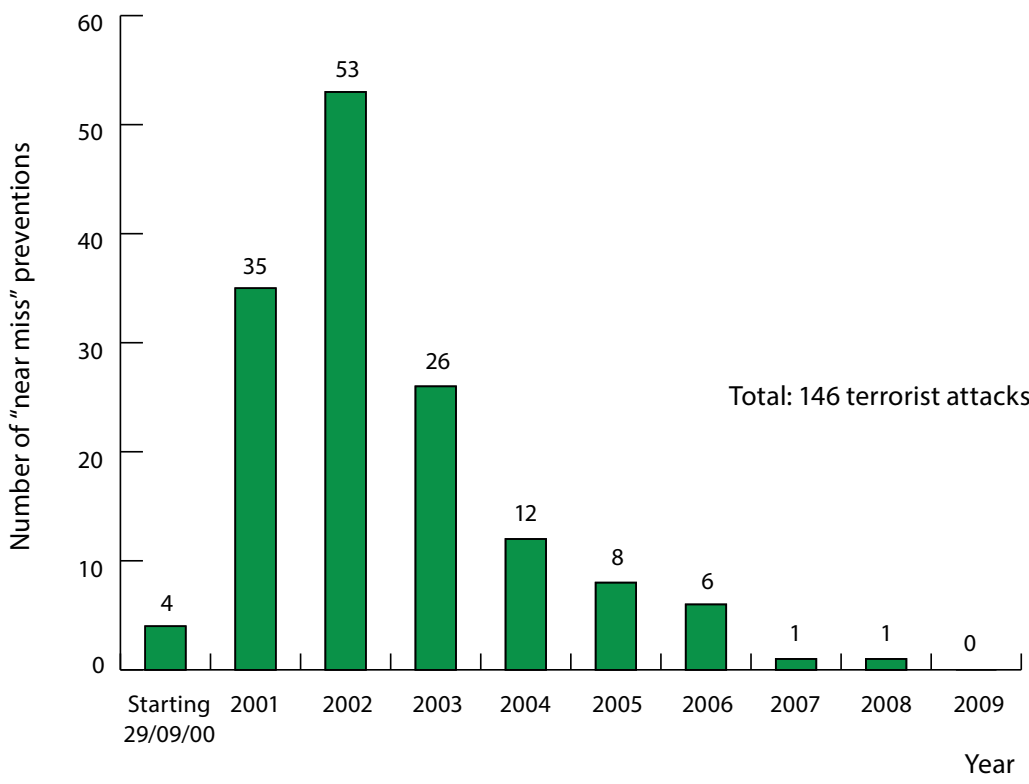

Figure 7. Distribution of "near miss" preventions during the years 2000-2009 


\section{Administrative Detainees}

Administrative detentions and court detentions serve as effective means of deterrence (Avinoam Sharon) and are considered a "non-violent" means of prevention which is in most cases possible prior to Stages 3, 6, 7 (Figure 2) [10]. In recent years various cells have been "leaving their mark" on the social networks, a development that both facilitates ISA operations but also poses a new challenge for intelligence forces. The contribution of administrative arrests may also be assessed by the number of Israelis killed in suicide bombings (according to ISA reports) which despite the fact that they account for no more than $0.6 \%$ of the total number of terrorist attacks carried out since the beginning of the struggle, the number of fatal casualties from such attacks accounts for almost $50 \%$ of all fatal casualties from terrorist activity. From this we can deduce that each time a suicide bombing plot is foiled by administrative detention, the lives of hundreds of people are saved. [6]

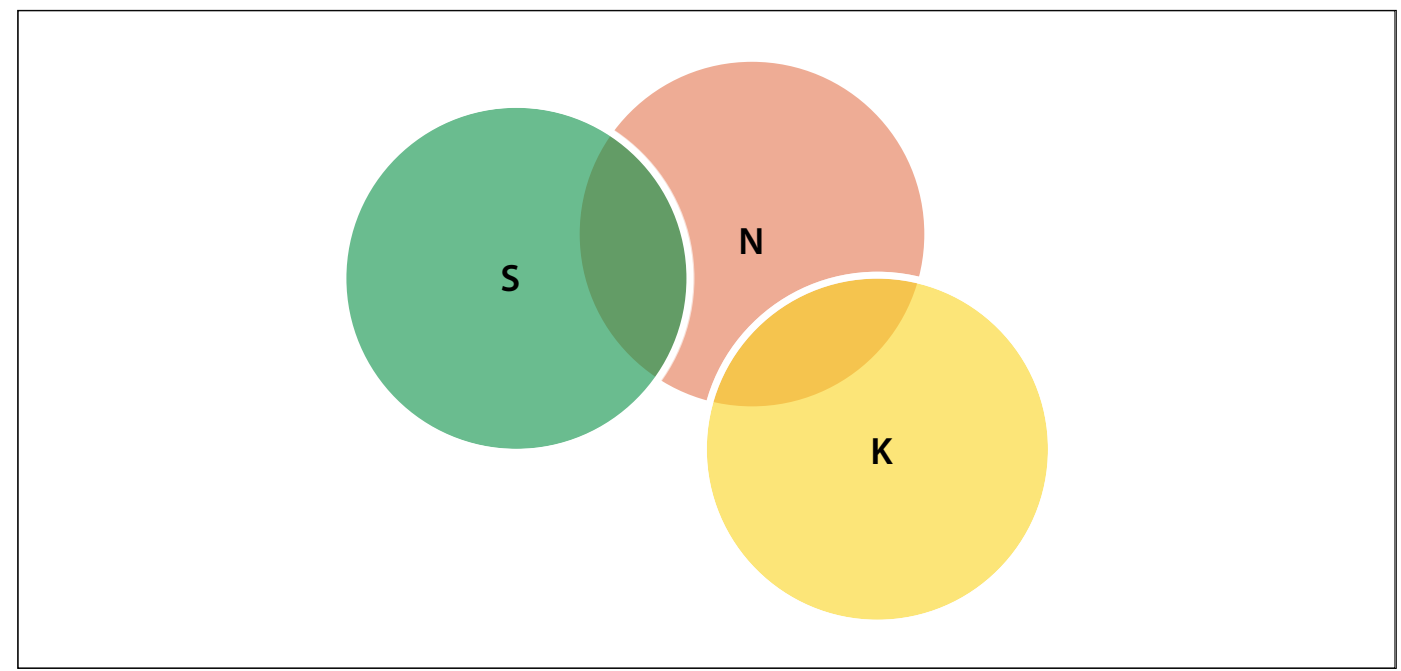

Figure 8. Statistical Venn diagram

In the diagram, the number of administrative detainees [11] is marked as " $K$ ".

The shared areas of $P, N$ and $K$ represent the effectiveness of interceptions $-F_{S}$ is the final number. It is not possible to make a quantitative calculation of administrative detainees. Our estimate is that during course of "Period 2" in the table, there were 24000 attacks while the number of detainees stood at 4000. Accordingly, the ratios between the two figures:

$\mathrm{K} \leq 0.15$

$\mathrm{K}$ - an estimate of the contribution of arrests to the prevention of attacks. 


\section{Conclusions}

To summarise, this article focuses on four topics:

1) coping with suicide bombings;

2) examination of terrorist networks and development of a theoretical model that allows discovery of terrorist cells;

3) analysis of the behaviour of terrorist cells and methods for early interception;

4) the impact of administrative detention.

Terrorist networks must be analysed as geographic information systems that may be analysed using graphical map. The cells that during preparation are exposed more times than older cells. The discovery of terrorist cells and exposure of their plans during the early preparation stage is vital.

Accordingly, more efforts must be invested in intelligence, including monitoring of social network forums and chats. Interception of such cells is very difficult due to the distributed structure under which the networks operate, without any military hierarchy. If a cell is not intercepted during early stages of preparation, later interception becomes much more difficult and is typically successful only after the cell has executed several attacks.

Administrative detentions play an important role in saving of civilian lives and contribute to the successful interception of attacks. Court Detentions are a punitive measure designed to deter individuals, not to intercept attacks in territories controlled by the Palestinian Authority. This provides networks with a relative advantage in organisation and execution of attacks, when the number of attacks is not affected by any negotiations or agreements (Oslo 1993). [2]

Successful combating, including vital support of intelligence units, has proven themselves successful in coping with suicide bombings (during 2002-2005 period). It was also shown that reduction in direct contact with Palestinians results in lower number of terrorist attacks (construction of the Fence in 2005).

\section{lespējamo teroristisko darbību prognozējamais modelis Rietumvalstīs}

\section{Kopsavilkums}

Pasaules terors kopumā un it ipaši terorisms Izraēlā liecina par to, ka pašnāvnieku terorakti ar spridzināmo ierīcu palīdzību izraisa ḷti lielu rezonansi un ir ḷoti efektīvi no teroristu mērḳu redzes viedokḷa. Neraugoties uz samērā nelielo teroristu pašnāvnieku absolūto daudzumu, bojāgājušo un ievainoto skaits tamlīdzīgos teroraktos var sasniegt lïdz 50\% no visu teroraktu upuru skaita. 
Šajā rakstā uzmanība ir koncentrēta uz šādiem jautājumiem: terorisma darbības novēršana sagatavošanas stadijā, darbības pārtraukšana pēc pirmā uzbrukuma, likvidēšana pēc teroraktu sērijas. Rakstā pievērsta uzmanība nelielām teroristu šūniṇām un motīviem, kas tās pamudina uzbrukumiem. Izanalizēts sīko terorisma posmu tīkla terorisma modelis un to darbỉbas raksturs.

Galvenie iemesli, kas pamudina teroristus izdarīt pašnāvības - tā ir vēlēšanās kḷut par "mocekli" ("šahīdu"), nenodot un nepievilt to cerības, kuri viṇus nosūtījuši. Tāpēc praktiski nav iespējams lauzt viṇu pārliecību. Dažās situācijās ir iespējama nelielu teroristu saišu uzbrukuma novēršana vai pārtraukšana.

Teroristu tīkli jāanalizē kā geogrāfiskās informācijas sistēmas, ko var izpētīt, izmantojot geogrāfijas karti. Vitāli svarīgi ir atklāt teroristu šūniņas un preventīvi novērst viņu plānu īstenošanu sagatavošanās agrīnā stadijā. Vairums organizatoru arestu un teroristu šūniṇu tiesāšana arī notiek teroraktu sagatavošanas etapā, bez vardarbīgas sagūstīšanas, kuru pavada militāras sadursmes ar drošības spēkiem, un tas palīdz izvairīties no liela upuru skaita. Gadījumā, kad saite nav atklāta pēc pirmā terorakta realizācijas, iespējas to atklāt vēlāk samazinās, un iespējams, ka teroristi tiks pieḳerti tikai pēc uzbrukumu sērijas.

Tāpēc vislielākās pūles jāiegulda tieši izlūkošanā, pievēršot uzmanību sociālo tìklu un sarunu kontrolei. Tādas informācijas pārtveršana ir ḷoti grūta teroristu tīkla sadalītās struktūras dēḷ, turklāt tỉkli darbojas bez jebkādas militārās hierarhijas. Liela nozīme civilpersonu dzīvību saglabāšanā un sekmīgai plānojamo uzbrukumu novēršanā ir aizdomās turamo administratīvā aizturēšana.

Atslēgvārdi: terors, teroristiskās organizācijas, teroristu tīkls, intifāda (sacelšanās), HAMAS, pretizlūkošanas dienests.

\section{References}

1. Alvesson, M. Knowledge work: ambiguity, image and identity. Human Relations, 2001. 54 (7): 863-864.

2. Dooleby, K. Organizational complexity. In M. Warner (ed.) International Encyclopedia of Business and Management. London: Thompson Learning, 2002. - Pp. 5013-5022.

3. Kaplan E. H., Kress M. Operational effectiveness of suicide-bomber-detector schemes: A best-case analysis. PNAS, 2005. 102 (29): 10399-10404.

4. Kaspit, Ben. The Jerusalem Intifada: Quiet, but alive and kicking. http://www.usnews.com/ news/articles/2014/10/24/jerusalems-silent-intifada (sk. 04.04.2016.).

5. Litvak, Meir. The Palestine Islamic Jihad: Background Information. The Jaffe Center for Strategic Studies \& The Moshe Dayan Center for Middle Eastern and Tel Aviv University African Studies, February 2003.

6. Maniv, Omri. The police presents: This is how we act against Jerusalem's Quiet Intifada. http://net.nana10.co.il/Article/?ArticleID=1087654 (sk. 04.04.2016.). 
David Gaft. Prediction Model for Probability of Terrorist Activities in the Western World

7. Matthew J. Morgan. The Impact of $9 / 11$ on Politics and War: The Day that Changed Everything? Palgrave Macmillan, 2009. - P. 222.

8. Mozes-Sadeh, T. Means Employed during the Recruitment and Training Process of Suicide Bombers. University of Haifa.

9. Sela, Avraham (ed). Arab-Israeli conflict. The Continuum Political Encyclopedia of the Middle East. New York: Continuum, 2002. - Pp. 58-121.

10. Sela, Avraham (Ed.) Arab-Israeli Conflict. The Continuum Political Encyclopedia of the Middle East. New York: Continuum, 2002. - Pp. 863-864.

11. Tabansky, Lior. The Fight against Terrorism in the Age of Information. Tel Aviv University: Harold Hartog School of Government and Policy, 2009.

12. The Quiet Jerusalem Intifada: 600 people killed, 130 wounded policemen - in 2 months. http://www.mako.co.il/news-channel2/young-edition-q4_2014/Article-b11b607aa659941004. htm (sk. 04.04.2016.). 


\title{
Nelegālā migrācija drošības nodrošināšanas kontekstā
}

\author{
Dr. iur. Andrejs Vilks \\ Rìgas Stradiña universitāte, Juridiskā fakultāte, \\ Tiesību zinātñu katedra, Latvija \\ Andrejs.Vilks@rsu.lv
}

\section{Kopsavilkums}

Sociāli politiskā un ekonomiskā situācija migrantu izcelsmes valstīs ir izteikti nelabvēlīga, un tas ietekmē nekontrolējamu bēgḷu un migrantu pieplūdumu Eiropas Savienības valstīs. ES ārējās robežas nav pietiekami nostiprinātas un drošas. Bēgḷu un migrantu izvietošanas punkti lielākoties nav nodrošināti ar nepieciešamajiem resursiem sociālās palīdzības sniegšanā. Migrantu vēlmes kḷūt materiāli nodrošinātiem, pilnīgi neatkarīgiem jaunajās, drošajās trešajās valstīs netiek piepildītas. Tas determinē sociālās spriedzes eskalāciju, konfliktu veidošanos starp patvēruma meklētājiem un trešo (Eiropas) valstu iedzīvotājiem. Konflikti pāraug sabiedriskās kārtības pārkāpumos un krimināla rakstura aktivitātēs. Samazinās nacionālā un starptautiskā drošība, kas ir saistīta ar strauju migrantu pieplūdumu Eiropā.

Atslēgvārdi: drošība, globalizācija, migrācija, nelegālā migrācija.

Augsts migrācijas līmenis ir ierasta mūsdienu civilizācijas iezīme. Gandrīz visas pasaules valstis ir iesaistìtas migrācijas procesos. Katru gadu miljoniem cilvēku visā pasaulē šķērso valstu robežas, lai iegūtu atbilstošu darbu ar labāku atalgojumu, piedalītos izglìtības programmās, atpūstos, sazinātos ar radiniekiem un citiem tuviem cilvēkiem vai arī izvairìtos no kriminālvajāšanas un sodu izpildes. Jāuzsver, ka piespiedu migrācija var būt saistīta ar militāriem konfliktiem, karadarbību un ekstremālām situācijām (dabas katastrofām, politiskā režīma maiṇu). Migrācijas procesu analīze var liecināt par neapmierinošiem sociāliem, tiesiskiem un politiskiem apstākḷiem konkrētā valstī, ekonomikas attīstības līmeni, cilvēku drošības stāvokli konkrētā pasaules reg̣ionā. Migrācijas tendences ir saistìtas ar atšḳirīgiem sadzīves apstākḷiem un dzīves līmeni, kā arī nelabvēlīgiem vides faktoriem. 
Ekonomikas zinātṇu doktors I. Brīvers atzīst, ka migrācija ir globalizācijas sekas un tas ir ilgstošs process. Tas ir skāris arī Latviju. Pēc viṇa domām, "ikviens, kurš aizbrauc, aizved no Latvijas vismaz 20 tūkstošus eiro. Tas ir naudas daudzums, kuru Latvija iztērēja, lai šos cilvēkus izaudzinātu un lai viṇi sasniegtu noteiktu izglìtības līmeni, tās ir Latvijas izmaksas, lai cilvēku sagatavotu darba tirgum" (Ivars Brīvers, 2016). Tomēr sakarā ar to, ka Latvijā nav nepieciešamo dzīves apstākḷu, valsts iedzivotāji ir spiesti emigrēt.

Aplūkojot migrācijas problēmu kopumā, ir jāatzīst, ka īpaši nelabvēlīga, ar grūti analizējamu procesu un nenosakāmām sekām ir nelegālā, nereǵistrētā un neoficiālā migrācija, kura netiek ietverta nevienā atskaites formā un apkopojumā.

Analizējot nelegālās migrācijas stāvokli, tendences un perspektīvas, pētnieki galvenokārt balstās uz apsekojumu rezultātiem un ekspertu vērtējumiem. Tomēr tie ir visai nosacīti un aptuveni. Bez šaubām, ir jāatzīst, ka šie vērtējumi l̦auj apzināt nelegālo migrantu stāvokli un plūsmu, kā arī tie ir migrācijas drošības pasākumu izstrādes pamats. Migrācijas drošîbu mēs saprotam kā sabiedriskās (sociālās, ekonomiskās, tiesiskās) un nacionālās (arī globālā kontekstā) sistēmas stāvokli, kurā netiek apdraudēta cilvēku dzīvība, veselība, gods, brīvības, īpašums un citas vērtības, kuras ir saistītas ar iedzīvotāju kontrolētu vai nelegālu pārvietošanos valsts vai transnacionālos ietvaros. Lat vijas nacionālajā attīstības plānā ir ietverta arī visai specifiska kategorija - drošumspēja (Cilvēka drošumspēja un NAP2020).

Aplūkotajā tematā mēs varam iekḷaut arī migrācijas drošumspēju kā cilvēku spējas un sabiedrības stāvokli (potenciālu) nenonākt apdraudētās situācijās un nezaudēt drošības sajūtu, kura ir saistîta ar migrācijas procesiem. Jāuzsver, ka ir iespējams diferencēt iedzīvotāju iekšējo pārvietošanos (vietējo migrāciju) un starpvalstu pārvietošanos (ārējo migrāciju). Raksta autors pievērsīsies galvenokārt tikai ārējās un nelegālās migrācijas tendenču un izpausmju analīzei.

Atbilstoši Starptautiskās darba organizācijas datiem nelegālie imigranti veido 10-15\% no kopējās migrācijas plūsmas apjoma (Rukovodstvo, 2006, 185). Neapšaubāmi, tas ir pietiekami augsts īpatsvars un var būtiski ietekmēt to valstu sociālo, ekonomisko un politisko stāvokli, kuras uzṇem migrantus. Augsta nelegālā migrācija ir vērojama no jaunattīstības valstīm uz valstīm ar augstu attīstības un dzìves līmeni. Pētỉjums, kuru ir veikusi "Pew Research", liecina, ka lielākais skaits imigrantu dzīvo ASV aptuveni 46 miljoni cilvēku (Connor, Cohn E Gonzalez-Barrera, 2006). Saskan̄ā ar Eiropas Universitātes institūta pētījumu ES valstīs ir aptuveni 43 miljoni viesstrādnieku, no kuriem 23 miljoni ir personas, kuras ir iebraukušas no citām valstīm. Pēc ekspertu atzinumiem patlaban ES valstīs ir aptuveni 6-10 miljoni nelegālo migrantu (Migration Reports, 2013).

Savukārt citu pētījumu rezultāti liecina, ka nelegālo migrantu skaits it krietni lielāks. Tiek atzīts, ka pašlaik ES valstīs ir vairāk nekā 33,5 miljoni migrantu (Migration and migrant population statistics, 2015). Lielākā daḷa migrantu ir izceḷotāji no Ziemeḷāfrikas un Āzijas valstīm. Izplatītākie nelegālo migrantu ieceḷošanas maršruti ir Rietumbalkānu un Vidusjūras austrumu regioni (Grieḳija, Turcija). Situācija nelegālās migrācijas 
jomā kopumā negatīvi ietekmē sabiedrisko drošību un arī dažu valstu nacionālo drošību. Eksperti uzskata, ka nelegālās migrācijas plūdi, kas līdztekus nes arī pieaugošo terorismu, ir neadekvātas ES migrācijas politikas sekas. Konsekventas migrācijas politikas trūkums nākotnē Eiropas valstīs var izraisìt vēl nelabvēlīgāku un kriminogēnāku situāciju.

Nelegālā migrācija pēc savas būtības ir nelikumīga cilvēku pārvietošanās pāri valstu robežām, pārkāpjot valsts noteikto ieceḷošanas, tranzìta, uzturēšanās un izceḷošanas kārtību ārvalstu pilsoṇiem un bezvalstniekiem.

Nelegālo migrāciju atkarībā no dažādiem faktoriem var iedalīt šādi:

- atkarībā no organizētības pakāpes - organizētā un neorganizētā migrācija;

- atkarībā no nelegālo migrantu aptvēruma - individuālā un grupveida migrācija;

- atkarībā no valstĩ iekḷuššanas paṇēmieniem - nelikumīga robežas šḳērsošana ar viltotiem dokumentiem, izmantojot nekontrolējamu robežu, ārpus kontrolpunktiem, uzturēšanās valstī pēc aț̣autā uzturēšanās perioda.

Augstais nelegālās migrācijas līmenis, kas ES aizvien pieaug, izraisa šajās valstīs virkni problēmu, jo rada negatīvas sekas un draudus sabiedrībai un cilvēkdrošībai. No kriminologiskā aspekta pieaugs sabiedrības kriminalizācijas līmenis. Nelegālie migranti ir "trešās valsts piederīgie, kuri ir pārkāpuši iecelıošanas vai uzturēšanās nosacỉjumus Latvijas Republikā - izmantojuši viltotus dokumentus vai snieguši nepatiesu informāciju, pārsnieguši uzturēšanās laiku vai pārkāpuši darba aț̣aujas nosacỉjumus, saṇēmuši atteikumu piešḳirt tiesisko statusu Latvijas Republikā" (Latvijas praktiskā rīcība nelegālās migrācijas mazināšanai: Pētījums, 2011).

Pretēji noteiktajai tiesiskajai kārtībai valstī uzturas nereǵistrēti cilvēki, kuru vidū ir personas, kas izvairās no atbildības par prettiesiska rakstura nodarỉjumiem, organizēto kriminālo grupu pārstāvji, teroristi. Nelegālie migranti daudzos gadījumos ir iesaistīti cilvēku un ieroču tirdzniecībā, narkobiznesā, akcīzes preču kontrabandā u. c. Daḷa nelegālo migrantu neoficiāli iesaistās darba tirgū, strādājot bez atbilstošām aț̣aujām un neregistrēti. Tas sekmē ēnu ekonomikas pieaugumu un korupcijas palielināšanos.

Serbijas politologs Miḷenko Nedel̨kovskis (Миленко Неделковски) uzskata, ka ir ḷoti aizdomīgi un nesaprotami, kāpēc $90 \%$ migrantu, kuri ieceḷo Eiropā, tostarp Maḳedonijā un Serbijā, ir jauni vīrieši (Nedelkovski, 2015). Neizpratni raisa tas, ka imigranti nāk no valstīm, kur to tradicionālā kultūra nepiel̦auj un neatbalsta gimeņu sairšanu un gimenes pamešanu. M. Nedel̦kovskis kā piemēru min Maḳedoniju, kurā pēc kara ar Serbiju ieceloja aptuveni 150 tūkstoši albāṇu, kuri būtiski mainīja valsts etnisko struktūru un kultūras tradīcijas. Liels jaunu vīriešu skaits raisa pamatotas aizdomas, ka viṇu iecel̦ošanas mērḳi var būt ekstrēmistisku un agresīva rakstura darbību veikšana.

Kā piemēru var minēt notikumus Jaungada naktī Ķelnē, kad aptuveni tūkstotis jaunu vīriešu, kuri bijuši apreibinošu vielu ietekmē, sarīkoja savdabīgus izklaides pasākumus pie pilsētas centrālās stacijas. Tika saṇemts vairāk nekā 100 sūdzību no sievietēm, kuras ir cietušas no seksuālas vardarbības. No šīm sūdzībām divas bijušas par izvarošanu, bet trīs ceturtdaḷas par seksuāla rakstura uzbrukumiem. Vīrieši pēc ārējām pazīmēm bija Tuvo Austrumu un Ziemeḷāfrikas izcelsmes. Turklāt sievietes tikušas 
arī aplaupītas un apzagtas, pret viņām ir veiktas netiklas darbības. Šādi incidenti bijuši arī Hamburgā un Štutgartē. Lìdzīgi gadījumi notikuši 12 Vācijas federālajās zemēs (pavisam Vācijā ir 16 federālās zemes). Analogiski uzbrukumi ir tikuši veikti Zviedrijā, Somijā un Šveicē. Aizdomas par viltotiem dokumentiem raisa arī tas, ka Serbijas robežsardzei 90\% imigrantu uzrāda kā dzimšanas datumu viena un tā paša gada 1. janvāri. Jāpiebilst, ka nav datubāzu, uz kurām balstoties varētu veikt ieceḷojošo personu identitātes pārbaudi.

Nelegālās migrācijas problēmu lokā nelegālās migrācijas organizēšanai ir viena no būtiskākajām nozīmēm. Migrantu kontrabanda ir organizēta personu pārvietošana, atvieglojot viṇu pārvietošanos pāri robežām, pārkāpjot noteiktos tiesību aktus, lai iegūtu finansiālu vai citu labumu no personām un organizācijām, kas iesaistìtas migrantu kontrabandā (sk. Apvienoto Nāciju Organizācijas Konvencija). Lielākais apdraudējums nāk nevis no darba n̦ēmēja migranta, kurš ir kḷuvis par objektu cilvēku kontrabandā, bet gan no organizētās noziedzỉbas sindikāta, kas nodrošina bēgḷu nelegālu pārvietošanos un sañem no viņiem lielas naudas summas. Migrantu kontrabanda ir starptautiska organizēta noziedzīga parādība ar augstu peḷnu un zemu risku.

Eksperti atzīst, ka nelegālās migrācijas organizēšana nes lielāku peḷnu nekā narkotiku tirdzniecība. Ir izpētīts, ka vieta patvēruma meklētāju laivā maksā divus līdz desmit tūkstošus dolāru, no kuriem 55 procentus saṇem nelegālās migrācijas organizētāji (Ilmārs Latkovskis, 2016).

ES valstīm ir ārējās robežas ar 21 valsti. No tām aptuveni divās trešdaḷās veidojas riska situācijas, kas nosaka iespējas organizēt caur šìm valstīm kontrabandas preču pārvešanu, narkotisko vielu tranzìtu, kā arī nodrošināt nelegālo migrantu ieplūšanu ES. ES valstīm sakarā ar to, ka Savienības valstu iekšējās robežas netiek kontrolētas, imigrācijas kanālu un plūsmu apzināšanai ir ḷoti būtiska nozīme. Kaut gan ES kopumā, kā arī tās dalībvalstis cenšas kontrolēt, fiksēt un pat ierobežot migrāciju, it īpaši nelegālo, tomēr jāatzīst, ka ir vērojama izteikta migrācijas krīze. Lìdzịgas izpausmes un aptvērums bija vērojams tikai pēc Otrā pasaules kara. Tomēr patlaban situācija migrācijā nav salīdzināma ar iepriekšējām. Demogrāfijas procesu pētnieks Hansens atzīst, ka tagad migrāciju var salīdzināt ar pašregulējamu piedāvājuma un priekšlikuma tirgu (Hansen, 2002, 583).

Nelegālā migrācija ir ne tikai drauds Eiropas Savienības drošībai kopumā, bet arī atsevišķām tajā ietilpstošajām valstīm. Būtiskākie nelegālās migrācijas draudi ir šādi:

- sabiedrības un valsts sociālā, teritoriālā un demogrāfiskā stāvokḷa deformācija;

- konkurence darba tirgū un cilvēku nodrošināšanā ar nepieciešamajiem dzīves apstākḷiem, tās saasināšanās;

- etnisko, relig̣isko (konfesionālo) un kultūras vērtību, uzvedības stereotipu un normu sadursme;

- atsevišķu reǵionu un jomu kriminalizācija;

- ekstrēmisma un ksenofobijas izpausmju pieaugums. 
Nelegālo migrantu pārvietošana pāri valstu robežām ir viens no lielākajiem ienākumu avotiem organizētajiem transnacionālajiem grupējumiem. Pirmkārt, atzīmēsim, ka pašreizējā geopolitiskā situācija, konflikti un karadarbība Sīrijā, sociālā un ekonomiskā krīze Afganistānā un Irākā ir izteikti labvēlīgs apstāklis ne tikai migrācijas procesu eskalācijai, bet arī starptautisku kriminālo grupējumu izveidei, lai pārvietotu bēgḷus pāri robežām. Otrkārt, nozīmīga ir šo grupējumu komplicētā darbība, kurai ir daudz dažādu darbības virzienu. Grupējumu pārstāvju darbība sākās ar mērḳtiecīgu informācijas novadīšanu potenciālajiem migrantiem par ḷoti labvēlīgajiem apstākḷiem jaunajās mītnes zemēs Eiropā (migranti būs nodrošināti ar augstiem pabalstiem, kas novērsīs nepiecieša mību strādāt, vinu rīcībā būs ekskluzīvas mājas un dzīvokḷi, automašīnas u. c.). Minētie dzìves apstākḷi, salīdzinot ar mītnes zemē esošajiem, neapšaubāmi, izklausās pasakaini.

Savervētie migranti tika nodrošināti ar pavadoṇiem, glābšanas vestēm, laivām un informāciju par mītni jaunajās patvēruma valstīs. Pēdējos gados Vācijā ikmēneša pabalsts personai, kura iesniedza pieteikumu par viṇas atzī̌sanu par bēgli, bija 670 EUR. Ja vēlāk iesniedzējam tika pieškirirts bēgḷa statuss, tad pabalsts jau bija vairāk nekā 1000 EUR. Turklāt bēgḷa statusa ieguvējam tika piešḳirts bezmaksas dzīvoklis un nodrošināts cits sociālais atbalsts (medicīniskie pakalpojumi, izglīīiba u. c.). Šãdi pievilcīgi sociālie apstākḷi motivēja iekḷūt attīstītajās Eiropas valstīs ne tikai cilvēkus no militārajā konfliktā iesaistītajām valstīm, bet arī no Eiropas valstīm (Kosovas, Maḳedonijas, Serbijas u. c.). Var secināt, ka virknē Eiropas Savienības valstu ir izteikti labvēlīga migrācijas politika (Francijā, Beḷgijā, Nīderlandē, Lielbritānijā, Zviedrijā). Imigrantiem ir radītas iespējas dzīvot nestrādājot. Ja, piemēram, ASV jau pirmajā uzturēšanās gadā valstī ir nodarbināti 94-97\% imigrantu (bezdarbs ir 4-7\%), tad terorisma plosītajās Beḷgijā un Francijā bezdarba līmenis imigrantu vidū sasniedz 35-50\%. Šie imigranti var būt apmierināti ar savu dzīves kvalitātes līmeni, bet to nevar saprast un nesaprot imigrantu bērni, kuri ir izstumti no tradicionālās Rietumu sabiedrības.

Turklāt imigrantu izvietošanas vietas ir koncentrētas pilsētu nomalēs, kur viniiem tiek celtas lētas, bet sociāli nodrošinātas mītnes. Tādējādi veidojas slēgtas sabiedrības daḷas (kopienas), kuras ir nodrošinātas bez nepieciešamās nodarbinātības. Tas ir savdabīgs piemērs un uzskatāms dzìves modelis imigrantu mītnes zemēs dzìvojošajiem, ka zināmu labklājỉbu ir iespējams sasniegt, neko nedarot. Veidojas deteritoriāla vide ar specifiskām vērtībām, sociālajām normām un dzīvesveidu, kurš nav raksturīgs ne jaunajā mītnes zemē, ne arī izcelsmes valstīs. Imigranti savā dzimtenē tiek uzskatīti par savdabīgu eliti, izredzētajiem un veiksminiekiem. Pētījumi liecina, ka aptuveni trešdaḷa imigrantu Francijā un puse Beḷgijā ir iebraukuši jaunajās mītnes zemēs, lai dzīvotu kopā ar radiniekiem (franču val. regroupement familial).

Pēc Eiropola rīcībā esošās informācijas viens migrants par cel̦ojumu no mìtnes zemes uz patvēruma valsti maksāja vidēji no trim līdz sešiem tūkstošiem ASV dolāru. Ekspertu aplēses liecina, ka 2015. gadā Eiropā ieradās vairāk nekā viens miljons bēglu u. Aptuveni $90 \%$ no viniiem maksāja kontrabandas organizētājiem. N̦emot vērā Eiropā 
nelikumīgi iecel̦ojušo migrantu skaitu, transnacionālo organizēto kriminālo grupējumu ienākumi tikai 2015. gadā varēja būt no trim līdz sešiem miljardiem ASV dolāru. Nelegālās migrācijas pieaugošie apjomi un atbilstošie organizēto kriminālo grupējumu ienākumi ḷāva pēdējiem iekḷūt "Kriminālās sfēras čempionu līgā". 2015. gadā vien Eiropols tika fiksējis 10700 personu, kuras turētas aizdomās par nelegālās migrācijas organizēšanu.

Eiropas Parlamentā 2015. gada 15. februārī tika apspriests jautājums, kuru ierosināja parlamenta deputāte Mara Bizoto (Mara Bizzotto), ka "Islāma valsts" (ISIS) ir iecerējusi un arī izmanto migrantu braucienus no Lībijas krasta uz "Eiropu, lai pārvērstu šo kontinentu par elli" [Priekšlikums]. To ir minējis bijušais Lỉbijas naftas un finanšu ministrs, apgalvojot, ka ISIS uzṇemas kontroli pār bēglu sūtišanu no Lïbijas, lai iefiltrētos tā saucamajos cerības braucienos. Nelegālā migrācija ir viens no būtiskākajiem faktoriem, kuri determinē terorisma draudus un to izpausmes Eiropā.

Pēc ārvalstu žurnālistu ziṇām, kuras ir publicētas izdevumā Sunday Express, 2015. gadā vairāk nekā 4000 "Islāma valsts" teroristu ir iekḷuvuši Eiropā kā bēg̣̣i (Brown, 2015). Gluži tāpat kā citiem nelegālajiem migrantiem, šo teroristu ieplūšanai ES valstīs palīdz organizētās kriminālās struktūras, kuras organizē bēgḷu nelikumīgu pārvietošanos no Ziemel̦āfrikas uz Turciju, Grieksiju un Itāliju. Palermo Prokuratūra vēl 2014. gada decembrī sāka izmeklēšanu par iespējamu ISIS teroristu maskēšanos par Lỉbijas un Sīrijas migrantiem, kas izsēdās Sicīlijas krastā. Starp nelegālajiem migrantiem, balstoties uz izlūkdienestu informāciju, Eiropā tika iepludināti no 400 līdz 600 labi sagatavotu teroristu, kuri izgāja apmācības teroristiskajā organizācijā "Islāma valsts". Eiropas valstīs ir izveidotas teroristisko grupējumu tīkla struktūras - šūniņas, kuras savā starpā nav saistītas. Grupām ir dots uzdevums darboties patstāvīgi, izvēloties uzbrukuma objektus, laiku un pañēmienus (Hinnat, Dodds, 2016).

Šo grupu identifikācijas grūtības ir saistītas ar to, ka to dalībnieki cits citu nepazīst, nezina viṇu dislokācijas vietas un komunikācijas līdzekḷus. Francijas parlamenta senatore Natālija Gulē (Nathalie Goulet) ir atzinusi, ka, ja agrāk būtu zināms, cik teroristu ir sagatavots Sīrijā un Irākā, kā arī par viṇu iekḷūšanu Eiropā, tad izdotos novērst 2016. gada 13. novembra un 2016. gada 22. marta teroristiskos aktus. Šo teroristisko aktu īstenotāju grupa bija cieši saliedēta un darbojās lielāka grupējuma ietvaros, kuras atzari ir Vācijā, Lielbritānijā, Itālijā, Dānijā, Šveicē un Turcijā. Pēdējā laikā ir mainījusies teroristisko grupējumu apmācības sistēma, stratēgija un metodika. Tiek izveidotas îpašas vienības. Mācību laiks ir garāks. Mērḳis pašreiz vairs nav nogalināt pēc iespējas vairāk cilvēku, palielināt upuru skaitu, bet gan palielināt teroristisko aktu un operāciju skaitu. Lìdz ar to pretinieks ir spiests tērēt vairāk naudas vai vairāk resursu. Arī iedzīvotāju vidū trauksmes sajūta un panika pieaug. Saistībā ar nelegālās migrācijas pieaugumu šāda veida uzbrukumu skaits varētu tikai pieaugt.

2006. gadā Latvijas Ārpolitikas institūts un Konrāda Adenauera fonds veica pētījumu par Latvijas imigrācijas politiku, tās problēmām un perspektīvām (Latvijas imigrācijas politika, 2006). Visaptverošā pētījumā tika paredzēti trīs iespējamie migrācijas 
politikas attīstības scenāriji: konservatīvais, liberālais un inkrementālais. Patlaban varētu konstatēt, ka Latvijas imigrācijas politikas īstenošanai vistuvākais bija liberālais imigrācijas attīstības modelis. ES integrācijas rezultātā tika atvērts darba tirgus, darba spēka plūsmai nekādi ierobežojumi netika paredzēti. Tomēr pētījumā formulētie ieteikumi netika pilnībā realizēti. Piemēram, ieteikums, ka "valstij daudz efektīvāk ir jāvēršas pret nelegālo uzñēmējdarbību", ir aktuāls arī pēc desmit gadiem.

2011. gadā tika izstrādāts un akceptēts pētījums "Latvijas praktiskās rīcības nelegālās migrācijas mazināšanai". Pētījuma secinājumos tika atzîts, ka "atbildīgo institūciju veikto pasākumu kopums nelegālās migrācijas mazināšanai gan pirms imigrantu ieceḷošanas, gan to ieceḷošanas un uzturēšanās laikā nodrošināja būtisku valsts iekšienē aizturēto nelegālo imigrantu skaita samazinājumu (no 310 personām 2008. gadā līdz 195 personām 2010. gadā)". Tomēr pēdējos gados atkal ir vērojams nelegālo migrantu straujš pieaugums Latvijā. Var tikai piekrist atzinumam, ka "pozitĩvu ietekmi uz Valsts robežsardzes kapacitāti valsts robežu apsardzībā atstājusi Valsts robežsardzes dalība starptautiskajās organizācijās, kā arī Eiropas Savienības projektu ietvaros iegādātās tehnikas un aprīkojuma pielietošana. Valsts robežas drošība efektīvi paaugstināta, modernizējot tehniskos līdzekḷus, kā arī paaugstinot atbildīgo personu kvalifikāciju”. L,oti būtiska nozīme nelegālās migrācijas novēršanai ir Valsts robežsardze.

Lai identificētu nelegālos imigrantus uz valsts robežas, saskaņā ar Robežsardzes likumu Valsts robežsardze veic virkni pasākumu (Robežsardzes likums):

- analizē nelegālās migrācijas risku;

- nodrošina nepārtrauktu valsts robežas uzraudzību, izmantojot tehniskos lìdzeklus un dienesta sunus;

- veic ieceļojošo personu, transportlīdzekḷu, kravu un mantu robežkontroli, izmantojot tehniskos līdzekḷus, kā arī nepieciešamības gadījumā nodrošina personu un transportlīdzekḷ pārbaudi valsts teritorijā;

- robežšḳērsošanas vietās (ostās, lidostās) veic iecel̦ojošo un izceliojošo personu profilēšanu.

Pozitīvi jāvērtē tas, ka 2015. gadā tika apstiprināts plāns “Indikatīvais rīcības plāns personu, kurām nepieciešama starptautiskā aizsardzība, pārvietošanai un uzṇemšanai Latvijā" (Indikatīvais rīcības plāns, 2015). Jāuzsver, ka tas ir izstrādāts pietiekami detalizēti un ietver sevī būtiskākos pasākumus, kā palīdzēt personām, kurām ir nepieciešama vispusīga aizsardzība. Tomēr ir vērojams mērḳtiecīgu, kompleksu, transnacionālu programmu un pasākumu trūkums nelegālās imigrācijas novēršanā un ierobežošanā, it īpaši, ja runa ir par migrantu izcelsmes valstīm. Var atzìt, ka kopumā Eiropā trūkst vienotas izpratnes un pieejas nelegālās un arī legālās migrācijas cēloṇu identifikācijā un konstruktīvas darbības to novēršanā. Šis globāla rakstura trūkums nespēj piepildīt vīzijas par drošu un labklājīgu nākotni. Valstu attīstības politiskā "labklājības valsts" modelis ir jāaizstāj ar "drošas valsts" modeli. 
Eiropas Savienībā kopumā var iezīmēt pasākumu virzienus, kuri varētu ierobežot nelegālās migrācijas apjomus:

- tiesisko aktu sankciju palielināšana par nelikumīgu robežas šḳērsošanu un nelegālās migrācijas organizēšanu;

- Eiropas Savienības ārējo robežu kontroles pastiprināšana, nodrošinot robežapsardzi (Frontex) ar nepieciešamajiem resursiem un labi sagatavotu personālsastāvu;

- vienota konsulārā un imigrācijas dienesta izveide ar kopēju datubāzi un kvalitatīvu sakaru sistēmu;

- vienota tiesisko aktu kopuma izstrāde un izveide par ārējo robežu šḳērsošanas kārtību un metodisko materiālu sagatavošanu par tiesisko aktu isstenošanas praksi;

- vienotas datubāzes un kārtības izveide iebraukšanas vīzu noformēšanā un izsniegšanā.

Eiropas Savienības politika nelegālās migrācijas ierobežošanā galvenokārt varētu būt saistīta ar kopēju piespiedu represīvo pasākumu izstrādi un realizāciju. Turklāt Eiropas valstīs būtu nepieciešama speciāla programma darbā ar imigrantiem, kas nav integrējušies sabiedrībā. Patlaban tā vēl nav Latvijas problēma, taču tas, ka imigranti neintegrējas Eiropā, var ietekmēt visu Eiropas valstu nākotni.

\section{Illegal Migration in the Context of Ensuring the Security}

\section{Abstract}

Unfavourable socio-economic situation of migrants in countries of origin causes a considerable and regular flow of migrants to the EU. Only some migrants try to become financially self-sufficient and socially integrated. Most of them try to get social protection and fully preserve national and religious identity. It may result in the growth of social tensions, conflicts between migrants and residents of countries where they receive shelter.

Uncontrolled migration leads to a breach of public order and criminal activity at the national level. It is also represents a threat to international security.

Presently, there are certain contradictions between the objective need for new workforce and the ability of socio-economic system to absorb a large number of migrants in Europe. Therefore, there is a need for a regular prognostication of migration risks and the development of methods, which will enable the migration management. Legal and institutional support for migration policies in Europe does not provide a prompt 
and effective migration management. Which emphasises the necessity of their improvement, especially taking into account the fact that Europe needs migrants to cope with the shortage of manpower and correct the demographic situation in general.

Keywords: globalization, illegal migration, migration, security.

\section{Literatūra un avoti}

1. Brown, Aaron. "Just wait..." Islamic State reveals it has smuggled thousands of extremists into Europe. 18.11.2015. Iegūts no: http://www.express.co.uk/news/world/555434// Islamic-State-ISIS-Smuggler-THOUSANDS-Extremists-into-Europe-Refugees

2. Apvienoto Nāciju Organizācijas Konvencija pret transnacionālo organizēto noziedzību. Pieñemts 15.11.2000. Starptautisks dokuments. Latvijas Vēstnesis, 87(2474), 06.06.2001. Iegūts no: http://likumi.lv/doc.php?id=25089

3. Cilvēka drošumspēja un NAP2020. Pārresoru koordinācijas centrs. Iegūts no: http://www.pkc. gov.lv/cilv\%C4\%93ka-dro\%C5\%A1umsp\%C4\%93ja-un-nap2020

4. Connor, P., Cohn, D'V., Gonzalez-Barrera, A. Changing Patterns of Global Migration and Remittances. Iegūts no: http://www.pewsocialtrends.org/2013/12/17/changing-patternsof-global-migration-and-remittances/

5. Hansen, R. Globalization, Embedded Realism, and Path Dependence The Other Immigrants to Europe. Comparative Political Studies, 2002, p. 583.

6. Hinnat, L., Dodds, P. IS trains 400 fighters to attack Europe in wave of bloodshed. AP News, 24.03.2016. Iegūts no: http://bigstory.ap.org/article/1c1661cef71c4a1a93f3a1863d27a284/ trains -400

7. Desilver, D. How the U.S. compares with other countries taking in refugees. PewResearchCenter, 24.09.2015. Iegūts no: http://www.pewresearch.org/fact-tank/2015/09/24// how-the-u-s-compares-with-other-countries-taking-in-refugees/

8. Ilmārs Latkovskis: migrācija ir daudz draudošāka problēma, nekā iepriekš esam apjautuši. Latvijas Republikas Saeima. Aktualitātes, 13.01.2016. Iegūts no: http://www.saeima.lv/lv/ aktualitates/saeimas-zinas/24280-ilmars-latkovskis-migracija-ir-daudz-draudosaka-problema-neka-ieprieks-esam-apjautusi

9. Indikatīvais rīcības plāns personu, kurām nepieciešama starptautiskā aizsardzība, pārvietošanai un uzṇemšanai Latvijā. Latvijas Republikas Iekšlietu ministrija, 29.09.2015. Iegūts no: http://www.iem.gov.lv/lat/patveruma_mekletaji_es_un_latvija/?doc=30 IS trains 400 fighters to attack Europe in wave of bloodshedIS trains 400 fighters to attack Europe in wave of bloodshed//http://bigstory.ap.org/article/1c1661cef71c4a1a93f3a1863 d27a284/trains-400-fighters-attack-europe-wave-bloodshed530http://www.iem.gov.lv/lat/ patveruma_mekletaji_es_un_latvija/?doc=30

10. Ivars Brīvers: Ekonomikas izaugsme nenozīmē labklājỉbas pieaugumu. Neatkarīgā, 17.03.2016. Iegūts no: http://nra.lv/latvija/166769-ivars-brivers-ekonomikas-izaugsme-nenozimelabklajibas-pieaugumu.htm

11. Latvijas imigräcijas politika: Problèmas un perspektìvas. Rīga: Latvijas Ārpolitikas institūts, 2006. 
12. Latvijas praktiskā rīcība nelegālās migrācijas mazināšanai: [Pētỉjums]. Rīga: Eiropas migrācijas tīkls, 2011. Iegūts no: http://ec.europa.eu/dgs/home-affairs/what-we-do/ networks/european_migration_network/reports/docs/emn-studies/irregular-migration/ lv_20120216_migracijasmazinasanai_lv_version_final_lv.pdf

13. Migration and migrant population statistics. Eurostat. 2015. URL. Iegūts no: www.ec.europa. eu/eurostat/statisticsexplaine d/index.php/Migration_and_migrant_population_statistics.

14. Migration Reports. EU Neighbourhood Migration Report 2013. Migration Policy Centre. Iegüts no: http://www.migrationpolicycentre.eu/publications/migration-report/

15. Nedelkovski, M. Kakvo donasjat Rotshildovi v ES: "90\% ot migrante ot Azija sa mladi mjze" Tjaxnata dostavka v ES se finansira ot organizaciite na Rotshildovi. 05.09.2015. (Неделковски, М. Какво Аонасят Ротшилдови в ЕС: “90\% от мигрантите от Азия са млаАи мъже” - Тяхната доставка в ЕС се финансира от организациите на Ротшицдови.). Iegūts no: www.zahariada.com/какво-Аонасят-ротшилдови-в-ес-90

16. Priekšlikums Eiropas Parlamenta rezolūcijai par teroristu iepludināšanu Itālijā, izmantojot slepeno imigrāciju. Eiropas Parlaments. Iegūts no: http://www.europarl.europa.eu/sides/ getDoc.do?pubRef=-//EP//TEXT+MOTION+B8-2015-0189+0+DOC+XML+V0//LV

17. Robežsardzes likums. Pieñemts 27.11.97. Likums. Iegüts no: http://likumi.lv/doc.php?id=46228

18. Rukovodstvo po pazrabotke effektivnoj politiki v oblasti trudovoj migraciji v stranax proisxozhdenija i naznacenija. (Руководство по разработке эффективной политики в области трудовой миграции в странах происхожАения и назначения.). OSCE, 23.05.2006. Iegūts no: http://www.osce.org/ru/eea/19243 


\title{
Teksta juridiskās ekspertīzes īpatnības lietās par naida izraisīšanu
}

\author{
Ëriks Trels \\ Rīgas Stradiṇa universitāte, Juridiskā fakultāte, Latvija \\ eriks.trels@gmail.com
}

\section{Kopsavilkums}

Saskaṇā ar Kriminālprocesa likuma 34. pantu procesa virzītājs var pieaicināt un ar lēmumu uzdot ekspertīzi veikt personai, kura nav ekspertīžu iestādes eksperts, bet kuras zināšanas un praktiskā pieredze ir pietiekama ekspertīzes izdarīšanai. Veicot ekspertīzes lietās par naida vai nesaticības izraisišanu, kas saistìtas ar personas nacionālo vai etnisko piederību, rasu vai relig̣isko pārliecību (Krimināllikuma 78. pants), vai atkarībā no personas dzimuma, vecuma, invaliditātes vai jebkuru citu pazīmju dẹl (Krimināllikuma 150. pants), pieaicinātajam ekspertam jābūt pietiekamām zināšanām un praktiskai pieredzei tieši šajā jomā, jāprot identificēt, atškịirt un norobežot abos pantos minētās darbības gan vienu no otras, gan arī no citiem Krimināllikumā paredzētajiem noziedzīgajiem nodarījumiem.

Par ekspertiem šādās lietās tika piesaistīti speciālisti no izglīîibas iestādēm (Latvijas Universitātes, Rīgas Stradiṇa universitātes), Tiesībsarga biroja, Valsts valodas ağentūras un neatkarīgām biedrībām (Sabiedriskās politikas centra "Providus" un Latvijas Cilvēktiesību centra). Tomēr, n,emot vērā tiesu prakses neesamỉbu lietās par sociālā naida izraisīšanu, gan tiesību normas piemērotājiem šo lietu izmeklēšanas gaitā, gan arī pieaicinātajiem ekspertiem, veicot teksta juridiskās ekspertīzes, jāsaskaras ar vairākiem problēmjautājumiem.

Atslēgvārdi: naida noziegumi, Krimināllikuma 78. pants, Krimināllikuma 150. pants, teksta juridiskā ekspertīze. 


\section{levads}

2014. gada 25. septembrī tika veikti kārtējie grozījumi Krimināllikumā (turpmāk $\mathrm{KL}$ ), kas pilnveidoja normatīvo regulējumu saistībā ar tā saucamajiem naida noziegumiem [6,22-28], paredzot atbildību par sociālā naida un nesaticības izraisīšanu [11]. Lìdz šim normatīvais regulējums paredzēja atbildību par darbību, kas vērsta uz nacionālā, etniskā, rasu (KL 78. pants) vai religiskā (līdz 2014. gada 29. oktobrim KL 150. pants) naida vai nesaticības izraisǐšanu. Ar veiktajiem grozijumiem jau esošās pazīmes (piederība pie noteiktas rases, etnosa vai tautības un relig̣iskās pārliecības), kas var kḷūt par iemeslu naida noziegumam, tika papildinātas ar šādiem kritērijiem: dzimums, vecums un invaliditāte, turklāt šo uzskaitïjumu veidojot kā nenoslēgtu kritēriju loku, jo atbildība ir paredzēta par darbību, kas vērsta uz naida vai nesaticības izraisǐšanu arī jebkuru citu pazìmju dēl [5, 97-99].

Grozījumi skāruši arī KL 78. pantu "Nacionālā, etniskā un rasu naida izraisīšana", kas skan šādi:

“(1) Par darbību, kas vērsta uz nacionālā, etniskā, rasu vai reliǵiskā naida vai nesaticības izraisīšanu, - soda ar brīvības atṇemšanu uz laiku lìdz trim gadiem vai ar islaicīgu brīvības atñemšanu, vai ar piespiedu darbu, vai ar naudas sodu.

(2) Par tādu pašu darbỉbu, ja to izdarījusi personu grupa vai valsts amatpersona, vai uzṇēmuma (uzṇēmējsabiedrības) vai organizācijas atbildīgs darbinieks vai ja tā izdarìta, izmantojot automatizētu datu apstrādes sistēmu, - soda ar brīīibas atṇemšanu uz laiku līdz pieciem gadiem vai ar īslaicīgu brīvības atṇemšanu, vai ar piespiedu darbu, vai ar naudas sodu.

(3) Par šã panta pirmajā dạ̦ā paredzēto darbību, ja tā saistîta ar vardarbỉbu vai draudiem vai ja to izdarijjusi organizēta grupa, - soda ar brīvības atṇemšanu uz laiku lỉdz desmit gadiem un ar probācijas uzraudzību uz laiku lỉdz trim gadiem vai bez tās." [12]

Savukārt KL 150. pantā "Sociālā naida un nesaticības izraisiš̌ana" noteikts:

“(1) Par darbību, kas vērsta uz naida vai nesaticības izraisiššnu atkarībā no personas dzimuma, vecuma, invaliditātes vai jebkuru citu pazīmju dẹl, ja ar to radīts būtisks kaitējums, - soda ar îslaicīgu brīvības atṇemšanu vai ar piespiedu darbu, vai ar naudas sodu.

(2) Par šā panta pirmajā dạ̦ā paredzēto noziedzīgo nodarījumu, ja to izdarījusi valsts amatpersona vai uzṇēmuma (uzṇēmējsabiedrības) vai organizācijas atbildīgs darbinieks, vai personu grupa vai ja tas izdarīts, izmantojot automatizētu datu apstrādes sistēmu, - soda ar brīvības atṇemšanu uz laiku lỉdz trim gadiem vai ar îslaicīgu brīvības atñemšanu, vai ar piespiedu darbu, vai ar naudas sodu.

(3) Par šā panta pirmajā dạ̦ā paredzēto darbỉbu, ja tã saistīta ar vardarbỉbu vai draudiem vai ja to izdarijusi organizēta grupa, - soda ar brīvības atn̦emšanu uz laiku lïdz četriem gadiem vai ar îslaicīgu brīvības atṇemšanu, vai ar piespiedu darbu, vai ar naudas sodu." [12] 
Veiktie grozījumi nav pretrunā arī Eiropas Drošības un sadarbības organizācijas Demokrātisko institūciju un cilvēktiesību biroja sniegtajai naida nozieguma definīcijai:

A) jebkurš noziedzīgs nodarỉjums, tostarp noziegums pret personu vai īpašumu, kad cietušais, vieta vai nozieguma mērḳis ir izvēlēti pēc to faktiskās vai šḳietamās saiknes, atbalsta, piederības vai dalības grupā, kas definēta B dalāă;

B) grupa var balstīties uz tās locekḷu reālu vai šḳietamu rasi, nacionālo vai etnisko izcelsmi, valodu, ādas krāsu, reliǵiju, dzimumu, vecumu, fizisko vai garīgo invaliditāti, seksuālo orientāciju vai citu līdzīgu pazìmi [28, 11].

Saskaṇā ar Iekšlietu ministrijas Informācijas centra datiem pēdējo piecu gadu laikā pēc KL 78. panta tika uzsākti 67 kriminālprocesi (2011. gadā - 12, 2012. gadā 17, 2013. gadā - 20, 2014. gadā - 8, 2015. gadā - 10) [2]. Statistiskie dati par 2015. gadu liecina arī, ka Ogres novadā ir uzsākts viens kriminālprocess pēc KL 150. panta trešās dal̦as. Analizējot tiesu praksi lietās pēc KL 78. panta, konstatējams, ka galvenais naidīgu izteikumu izplatišanas avots ir internets.

Darba mērḳis - sākt diskusiju par iespējamiem problēmjautājumiem, kas saistīti ar Krimināllikuma 78. un 150. panta piemērošanu.

Materiāls un metodes - temata analīze veikta starpdisciplināri, izmantojot šādas vispārīgās pētniecības metodes: salīdzināšanu un apkopojumu, cēloṇsakarību atklāšanu, analīzi un sintēzi.

\section{Rezultāti un diskusija}

Procesa virzìtājiem, izmeklējot ar naidu un neiecietību saistītos noziegumus, kas tika izdarīti interneta vidē, kā arī pieaicinātiem ekspertiem, veicot teksta juridiskās ekspertīzes, pirmkārt, ir nepieciešams nošḳirt naida noziegumus no aizspriedumiem un stereotipiem.

Aizspriedumi ir kādas nacionālas, etniskas, rasu, reliǵiskas vai sociālas grupas un tās dalībnieku negatīvs vērtējums. Tie ir objektīvi nepamatoti pien̦ēmumi "par kādu cilvēku, cilvēku grupu vai sabiedrības parādību. Aizspriedumu pamatā ir nepareizi vai kḷūdaini vispārinājumi, kā arī strikta un nelokāma attieksme, un to rašanos veicina sociālā distance - grupu, kas atšḳiras pēc sociālā stāvokḷa, tautības, reliǵijas utt. dzīves nošḳirtība" $[1,63]$.

Savukārt stereotipi ir noturīgie aizspriedumi. Latvijas Cilvēktiesību centra darbinieki skaidro, ka stereotipi ir "vispārēji, vienkāršoti, noturīgi priekšstati par dažādām sociālām, arī etniskām grupām ar tām raksturīgām ìpašî̉ām. Stereotipi veidojas cilvēku sociālās izziṇas un sociālo parādību kategorizācijas procesā. Svarīgs stereotipu aspekts ir tāds, ka tie nebalstās uz objektīvu patiesību, bet pamatojas uz diezgan subjektīviem un bieži vien nepārbaudāmiem apgalvojumiem un pieņēmumiem" [1, 13].

Publiskā telpā stereotipi ir visai izplatīit. Pie stereotipiem jāpieskaita, piemēram, uzskati: "visi čigāni ir zaglil" vai "visi musulmaṇi ir teroristi". Pieaicinātajiem ekspertiem, veicot teksta juridiskās ekspertīzes, bieži jāsaskaras ar kḷŭdainiem vispārinājumiem un 
pieṇēmumiem par kādu grupu. Pie aizspriedumiem jāpieskaita, piemēram, uzskati, ka "visi X tautības pārstāvji ir debili" [26]. İstenojot principu "Nedari citam to, ko nevēlies, lai darìtu tev", kā arī lai noskaidrotu, vai analizējamais izteiciens ir aizskarošs, šeit un turpmāk raksta autors piedāvā nezināmo elementu " $X$ " aizvietot ar šì raksta lasītāja tautību vai citu atbilstošu kritēriju.

Veicot teksta juridiskās ekspertīzes, pieaicinātajiem ekspertiem jāatceras, ka aizspriedumi vai naids pret indivīdiem vai sabiedrības grupu etniskās piederības, rases, relig̣ijas, seksuāās orientācijas, valodas, invaliditātes u. c. pazīmju dẹl ir naida noziegumu pamatā $[4,3]$.

Otrkārt, veicot teksta juridiskās ekspertīzes, ir nepieciešams pievērst īpašu uzmanību aicinājumiem veikt prettiesiskas darbỉbas pret kādu nacionālu, etnisku, rasu, relig̣isku vai sociālu grupu. Tas varētu būt aicinājums veikt kādu tīšu darbību ar nolūku pilnīgi vai daḷēji iznīcināt kādu cilvēku grupu kā tādu (pie šādiem izteicieniem pieskaitāms, piemēram, šāds komentārs: "Nāvi [X grupas pārstāvjiem]! Visus krāsnī! Sākot ar zìdainiem un beidzot ar vecāmmātēm! Lai neviens nepaliek!!!" [20]); aicinājums grupas locekḷus nogalināt (piemēram, "Labs [X grupas pārstāvis] - miris [X grupas pārstāvis]" [25]); aicinājums grupas locekḷiem nodarīt miesas bojājumus (piemēram, "Nu ko, ejam sist [X grupas pārstāvjus]" [24]); aicinājums lietot līdzekḷus, kuru mērḳis ir novērst bērnu dzimšanu šādā grupā (piemēram, "[X grupas pārstāvjus] kā sugu vajag kastrēt jau kopš dzimšanas" [24] vai "[X grupas sieviešu kārtas personām vajag iesist] ar kieǵeli pa vēderu, lai nevar reproducēties" [27]), vai aicinājums izdarīt kādas citas prettiesiskas darbības pret šo grupu.

Parasti aicinājums tiek izteikts, izmantojot darbības vārdus pavēles izteiksmē (jeb imperatīvā). Darbības vārds pavēles izteiksmē tiek lietots, ja ar to tiek izteikta pavēle, pamudinājums, aicinājums, lūgums. Tomēr krimināltiesību zinātnieki norāda, ka dažreiz aicinājumi tiek izteikti aizplīvurotā veidā, izmantojot darbības vārdus vēlējuma izteiksmē $[29,69-72]$ vai izmantojot izteicienus "būtu labi, ja", "es vēlètos, lai" u. c. [30, 68-69]. Darbības vārds vēlējuma izteiksmē tiek lietots, ja tiek norādīts uz vēlamu darbỉbu, kas noteiktos apstākḷos var būt iespējama vai neiespējama. No piemēriem ir redzams, ka dažreiz aicinājumi tiek izteikti aizplīvurotā veidā, izmantojot alegorijas (notikumi un parādības tiek atspoguḷotas simboliski, nevis stāstoši), metaforas (viens no mākslinieciskās izteiksmes līdzekḷiem, kas bieži tiek izmantots dzejā) vai retoriskus jautājumus (jautājumus, uz kuriem nav nepieciešama atbilde). "Retoriskajos jautājuma teikumos izsaka apgalvojumu vai noliegumu. Teikumam jautājuma modalitāte tiek pieškirta stilistiskos nolūkos - galvenokārt, lai izceltu kāda apgalvojuma vai nolieguma kategoriskumu." [3, 630] Savukārt par metaforas piemēru var kalpot komentārs, kurā persona pauž uzskatus, ka X grupas pārstāvjus "var izārstēt tikai ar svinu pakausī” [22]. Parasti ar metaforām "lodi pakausī”, "deviniem gramiem pakausī” jeb "svinu pakausī" literatūrā saprot nāves soda piemērošanu civiliedzīvotājiem un karagūstekṇiem, nogalinot viṇus ar šāvienu pakausī. Šādā veidā sodus piemēroja varas pārstāvji PSRS un nacistiskās Vācijas okupācijas laikā (vēlāk šie noziegumi tika kvalificēti kā genocīds, kara noziegumi un noziegumi pret cilvēci). 
Viens no pirmajiem gadījumiem, kad metafora tika izmantota, lai aizplīvurotu naidu kurinošus izteikumus, bija 2007. gada 22. februārī, kad Latvijas antifašistiskās komitejas organizētās diskusijas "Nacisma, neonacisma un ksenofobijas problēmas Latvijā" laikā kāds radikālās organizācijas pārstāvis publiski salīdzināja sev netīkamās tautas ar gangrēnu, kas jānogriež [21]. Izskatot lietu pirmajā instancē, Rìgas apgabaltiesas Krimināllietu tiesas kolēgija 2008. gada 6. martā atzina personu par vainīgu un sodīja ar brīvības atṇemšanu uz vienu gadu, taču, tā kā tai jau bija neizciesta sodāmība, galīgais sods bija noteikts brīvības atṇemšana uz vienu gadu un sešiem mēnešiem. Augstākās tiesas Krimināllietu tiesu palāta apelācijas instancē minēto spriedumu atcēla dạ̦ā par noteikto galīgo sodu un sodija vainīgo ar brīvības atṇemšanu uz diviem gadiem un vienu mēnesi. Izskatot lietu sakarā ar kasācijas sūdzību, Augstākās tiesas Senāta Krimināllietu departaments šo spriedumu atcēla un lietu nosūtīja jaunai iztiesāšanai apelācijas instances tiesai. Tāpat kasācijas instances tiesa grozīja apsūdzētajam piemēroto drošîbas lïdzekli no apcietinājuma uz sūtijumu saṇemšanas adreses paziṇošanu. 2010. gada 22. februārī Augstākās tiesas Krimināllietu tiesu palāta, atkārtoti apelācijas instancē iztiesājot krimināllietu, atcēla pirmās instances tiesas spriedumu, atzina personu par nevainīgu un attaisnoja, jo personai inkriminētajās noziedzīgajās darbībās nav KL 78. panta pirmajā dạ̣a paredzētā noziedzīgā nodarỉjuma sastāva objektīvās puses pazìmju [18]. 2010. gada 21. maijā Augstākās tiesas Senāts pieñēma lēmumu, kas nav pārsūdzams: apelācijas instances tiesas spriedumu atstāt negrozītu, kasācijas sūdzību noraidìt [17]. Pēc šĩs lietas izpētes jākonstatē, ka dažādās tiesās, vērtējot konkrētajā lietā iegūtos pierādījumus, pieṇemti diametrāli pretēji lēmumi, kas savukārt liecina par Eiropas Komisijas pret rasismu un neiecietību ekspertu kritikas pamatotību, jo konsolidētas tiesu prakses trūkums saistībā ar KL 78. panta piemērošanu un kūdīšanas uz naidu šaurā interpretācija traucē piemērot šìs normas [7, 15-16].

Treškārt, pieaicinātajam ekspertam jābūt pietiekamām zināšanām un praktiskai pieredzei, lai noškirtu darbības, par kurām ir paredzēta atbildība KL 78. pantā, no KL 150. pantā minētajām darbībām.

KL 78. panta pirmajā dạ̦ā ietvertais noziedzīgais nodarījums ir klasificēts kā mazāk smags noziegums, turpretĩ otrajā dạ̣a - kā smags noziegums, bet panta trešajā dạ̦ā - kā sevišşi smags noziegums. Salīdzinājumam KL 150. pantā ietvertais noziedzīgais nodarījums panta pirmajā dạ̣ā klasificēts kā kriminālpārkāpums, otrajā dạ̣ā - kā mazāk smags noziegums, bet panta trešajā daḷā - kā smags noziegums.

Tas, ka par KL 78. pantā ietverto darbību paredzētie sodi ir bargāki nekā par KL 150. pantā minēto darbību, rada absurdu situāciju, jo par darbību, kas vērsta uz etniskā naida vai nesaticības izraisīšanu interneta vidē, piemēram, pret krievu tautības pārstāvjiem, bargākais no paredzētajiem sodiem būs brīvības atṇemšana uz laiku lïdz pieciem gadiem, bet par līdzīga rakstura darbību pret nepilson,iem vai pret krievvalodīgajiem kā pret sociālo grupu, kas veidota pēc kopīgās valodas kritērija, - uz laiku līdz trim gadiem. 
Līdzīga situācija izveidosies, kad naids vai nesaticība interneta vidē būs izraisìta pret patvēruma meklētājiem, bēgliem un personām ar alternatīvu statusu vai pret migrantiem, nenorādot šo personu nacionālo, etnisko, rasu vai religisko piederību. Tas nozīmē, ka notiesātajām personām pieškirtie sodi atšķirsies atkarībā no tā, kā attiecīgā komentārā minētās grupas bija nosauktas. Piemēram, par interneta vidē ievietoto izteicienu "Visus bēglus vajag iznīcināt!" draud sods līdz trīs gadiem, bet par izteicieniem "Visus šos melnos bēglus vajag iznìcināt!" vai "Visus šos musulmaṇu bēglus vajag iznīcināt!" - līdz pieciem gadiem.

Minētajos piemēros noziedzīgo nodarījumu raksturs un radītais kaitējums ir lïdzīgs, un, pēc autora domām, likumdevējs nav ievērojis konsekvenci, paredzot atšḳirīgas soda sankcijas par līdzīgiem noziegumiem.

Būtiska problēma ir saistīta ar KL 78. un 150. panta atšḳirīgu institucionālo piekritību. Saskaņā ar Kriminālprocesa likuma 387. pantu "Drošības policijas pilnvarotas amatpersonas izmeklē noziedzīgus nodarījumus, kas izdarīti valsts drošības jomā vai valsts drošības iestādēs, vai citus noziedzīgus nodarījumus savas kompetences ietvaros un gadijjumos, kad izmeklēšanu uzdevis veikt generālprokurors" [13]. KL 78. pants ir ietverts IX nodalāa "Noziegumi pret cilvēci, mieru, kara noziegumi, genocīds", kas ir Drošības policijas piekritībā. Šĩs iestādes piekritībā ir arī KL X nodaḷa "Noziegumi pret valsti”. Savukārt KL 150. pants ir ietverts XIV nodaḷā "Noziedzīgi nodarījumi pret personas pamattiesībām un pamatbrīvībām", kas ir Valsts policijas kompetencē.

Autors uzskata, ka būtu lietderīgi pārcelt pantu, kas paredz atbildību par sociālā naida un nesaticības izraisǐšanu, KL X nodạ̦ā "Noziegumi pret valsti”, lai tas nonāktu Drošības policijas institucionālā piekritībā. Minētā priekšlikuma îstenošana l̦aus uzsvērt, ka sociālā naida un nesaticības izraisǐšana ir apdraudējums valsts drošỉbai, kā arī dos iespēju lietderīgi izmantot Drošỉbas policijas pieredzi šajā jomā un tās rīcībā esošos resursus.

Ceturtkārt, veicot teksta juridiskās ekspertīzes, pieaicinātajam ekspertam ir nepieciešams nošķirt KL 78. un 150. pantā minētās darbības no citiem KL paredzētajiem noziedzīgajiem nodarījumiem. Tā, piemēram, komentāra "Vai vēl neapnika par savu lohokaustu melot? Atkal kompensācijas izsist gatavojaties?... holokausts ir vien židu mits ..." [19] autors publiski noliedz Otrā pasaules kara laikā pret ebreju tautu istenoto genocīdu (KL 74. ${ }^{1}$ pants), bet aicinājums "sarīkot Latvijas Maidanu" [23] ir vērsts uz valsts varas gāšanu (KL 81. pants), savukārt aicinājums "izveidot Latgales tautas repub$l i k u$ ” ir vērsts uz Latvijas Republikas teritoriālās vienotības graušanu (KL 83. pants).

Pieaicinātajam ekspertam dažreiz jāsaskaras ar noziedzīgā nodarījuma daudzpusību, kad ekspertīzei pakḷautajā komentārā iekḷautie izteicieni atbilst divu vai vairāku dažādu noziedzīgu nodarījumu sastāvu pazīmēm. Piemēram, teikumā "Žēl, ka holokausts ir vien žīdu mìts... Jūs nedrīkstat eksistēt uz šis planētas" [19] personas darbībā vienlaikus saskatāma gan Otrā pasaules kara laikā pret ebreju tautu īstenotā genocīda publiskā noliegšana (KL 74. ${ }^{1}$ pants), gan aicinājumi pilnīgi iznīcināt ebreju tautības pārstāvju grupu kā tādu (KL 78. pants). 
Un, piektkārt, pieaicinātajam ekspertam ir nepieciešams izvērtēt ekspertīzei nodotos izteikumus vārda brīvības nodrošināšanas kontekstā. Veicot teksta juridiskās ekspertīzes, ekspertam ir jāatceras, ka vārda brīvība ir attiecināma ne tikai uz "informāciju" vai "idejām", kas tiek uztvertas labvēlīgi vai neitrāli, bet arī uz tām, kas apvaino, šokē vai uztrauc kādu sabiedrības daḷu [16]. Diskutablās informācijas klāstā ietilpst arī jautājumi par vēsturisko notikumu atšḳirīgu interpretāciju, kas varētu aizskart kā vēsturisku notikumu dalībniekus, tā arī viṇu radiniekus un citas iesaistītās personas [15].

Vienlaikus jāuzsver, ka ārpus vārda brīvības robežām paliek vēsturisko notikumu interpretācija, kas saistīta ar

\footnotetext{
"īstenotā genocīda, nozieguma pret cilvēci, nozieguma pret mieru vai kara nozieguma, tai skaitā PSRS vai nacistiskās Vācijas īstenotā genocīda, nozieguma pret cilvēci, nozieguma pret mieru vai kara nozieguma pret Latvijas Republiku un tās iedzīvotājiem, publisku slavināšanu, noliegšanu, attaisnošanu vai rupju noniecināšanu" (KL 74. ${ }^{1}$ pants).
}

Latvijas Republikas Satversmes 100. pants, 1950. gada 4. novembra Eiropas cilvēku tiesību un pamatbrīvību aizsardzības konvencijas 10. pants un ANO 1966. gada 16. decembra Starptautiskā pakta par pilsoṇu un politiskajām tiesībām 19. pants garantē tiesības uz vārda brīiību. Tomēr gadījumos, kad tekstā ir izplatīti uzskati, kas aicina veikt noziedzīgus nodarījumus, tai skaitā ja tie ir vērsti uz nacionālā, etniskā, rasu, religíiskā vai sociālā naida un nesaticības izraisīšanu, šādu uzskatu izplatî̌ana netiek aizsargāta ar šajos normatīvajos aktos ietvertajām tiesībām uz vārda brīvību.

Cilvēku tiesību un pamatbrīvību aizsardzības konvencijas 10. panta 2. punktā noteikts:

“Tā kā šo brīvību īstenošana ir saistīta ar pienākumiem un atbildỉbu, tā var tikt pakḷauta tādām formalitātēm, nosacījumiem, ierobežojumiem vai sodiem, kas paredzēti likumā un nepieciešami demokrātiskā sabiedrībā, lai aizsargātu valsts drošības, teritoriālās vienotības vai sabiedriskās drošības intereses, nepieḷautu nekārtības vai noziegumus, aizsargātu veselību vai morāli, aizsargātu citu cilvēku reputāciju vai tiesības, nepiel̦autu konfidenciālas informācijas izpaušanu vai lai saglabātu tiesas autoritāti un objektivitāti." [9]

Arī Starptautiskā pakta par pilsoṇu un politiskajām tiesībām 19. panta 3. punktā noteikts, ka

"paredzēto tiesību izmantošana uzliek īpašus pienākumus un atbildību. Tāpēc tā var būt pakḷauta zināmiem ierobežojumiem, taču tiem jābūt likumā noteiktiem un nepieciešamiem:

a) citu personu tiesību un reputācijas cienīšanai;

b) nacionālās drošības, sabiedriskās kārtības, sabiedrības veselības vai tikumības aizsardzībai" [8].

Eiropas Cilvēktiesību tiesa ir atzinusi, ka iecietība un visu cilvēku pašcieñas un vienlīdzības ievērošana ir demokrātiskās un plurālistiskās sabiedrības pamats. Ievērojot šo principu, demokrātiskā sabiedrībā ir nepieciešams piemērot sankcijas par jebkādām izteiksmes formām, kas vērstas uz naida un neiecietības izplatǐšanu, izraisī̌̌anu, stimulěšanu un attaisnošanu [14]. 


\section{Secinājumi}

1. Publiskā telpā izplatītie aizspriedumi un stereotipi, kas aizskar cilvēku cieṇu, iziet ārpus Latvijas Republikas Satversmes 100. pantā, 1950. gada 4. novembra Cilvēka tiesību un pamatbrīvību konvencijas 10. pantā un ANO 1976. gada 23. marta "Starptautiskā pakta par pilsoṇu un politiskajām tiesībām" 19. pantā noteiktajām tiesībām uz vārda brīvību. Kaut arī aizspriedumi un stereotipi parasti nav vērtējami kā uzskati, kas apzināti vērsti uz nacionālā, etniskā, rasu, religiskā vai sociālā naida vai nesaticības izraisišanu, tie var kḷūt par motīvu šādam noziedzīgam nodarījumam, tāpēc šādu uzskatu izplatīšana nav vēlama.

2. Publiskajā telpā izplatītie uzskati, kas vērsti uz nacionālā, etniskā, rasu, religiskā vai sociālā naida un nesaticības izraisiš̌anu, iziet ārpus Latvijas Republikas Satversmes 100. pantā, 1950. gada 4. novembra Eiropas cilvēku tiesību un pamatbrīvību aizsardzības konvencijas 10. pantā un ANO 1966. gada 16. decembra Starptautiskā pakta par pilsoṇu un politiskajām tiesībām 19. pantā noteiktajām tiesībām uz vārda brīvību.

3. Personas tiesību un pamatbrīvību izmantošanai vai realizēšanai jābalstās uz vienlīdzības pamatiem. Autors uzskata, ka būtu lietderīgi veikt grozījumus Krimināllikumā un pielīdzināt par sociālā naida un nesaticības izraisīšanu (KL 150. pants) paredzētās soda sankcijas sankcijām, kas paredzētas par nacionālā, etniskā un rasu naida izraisǐšanu (KL 78. pants).

4. Būtu lietderīgi arī pārcelt pantu, kas paredz atbildību par sociālā naida un nesaticības izraisīšanu, KL X nodaḷā "Noziegumi pret valsti".

5. Interneta vidē publicētie izteikumi, kas vērsti uz nacionālā, etniskā, rasu, relig̣iskā vai sociālā naida un nesaticības izraisiš̌anu, būs publiski apriori, jo tie ir pieejami neierobežotam interneta lietotāju lokam visā pasaulē. Savukārt divu personu savstarpēji paustie naidīgie uzskati par kādu nacionālu, etnisku, rasu, relig̣isku vai sociālu grupu nav uzskatāmi par publiskiem. Tādējādi aizskaroša un naidīga vēstule, kuru saṇēmis viens adresāts, nerada sūtītājam nekādas sekas, ja vien tajā nav saskatāms kāda cita noziedzīga nodarījuma sastāvs, piemēram, draudi izdarìt slepkavību vai nodarīt smagus miesas bojājumus (KL 132. pants).

6. Tiesību piemērotājam jāpārliecinās, ka konkrētajā situācijā nodarījums ir vērsts pret kādu grupu, nevis pret šìs grupas pārstāvi, pamatojoties tikai uz personisku nepatiku.

7. Tiesību piemērotājam jāatceras, ka dažreiz naidīgie aicinājumi tiek izteikti aizplīvurotā veidā, izmantojot darbības vārdus vēlējuma izteiksmē, izteicienus "būtu labi, ja", "es vēlētos, lai" vai uzdodot retoriskus jautājumus, lai izceltu kāda apgalvojuma vai nolieguma kategoriskumu . Naidīgie teksti tiek slēpti, arī izmantojot mākslinieciskās izteiksmes līdzekḷus - alegorijas, metaforas, epitetus, ironiju, perifrāzi, personifikāciju, salīdzinājumus, simbolus u. c. 
8. Palielinoties patvēruma meklētāju un migrantu daudzumam Eiropā, turpina pieaugt sociālā spriedze arī Latvijā un citur Eiropā, un raksta autors paredz, ka šìs spriedzes rezultātā pieaugs arī lietu skaits par nacionālā, etniskā, rasu, religiskā vai sociālā naida un nesaticības izraisiš̌anu.

\section{Legal Expertise Features of the Text in Cases of Hatred Triggering}

\section{Abstract}

In the Section 34 of the Criminal Procedure Law, it is stated: A person directing the proceedings may invite, and assign with a decision, a person to perform an expertexamination who is not an expert of an expert-examination institution, but whose knowledge and practical experience is sufficient for the performance of the expertexamination. Examining cases of hatred or enmity related to personal or national or ethnic, racial or religious beliefs (Section 78 of the Criminal Law), or according to sex, age, disability or any other features of a person (Section 150 of the criminal Law), an invited expert must have sufficient knowledge and practical experience in this area, be able to identify, distinguish and delimitate actions mentioned in both articles, and other criminal offences provided for in the Criminal Law. As experts in such cases were involved specialists from the educational institutions (The University of Latvia, Riga Stradiňš University), as well as the Ombudsman's Office, the Latvian Language Agency and Non-governmental Organisations (Centre for Public Policy PROVIDUS, The Latvian Centre for Human Rights). However, given the lack of case law in matters of social hatred triggering the law, applicants during the investigations of these cases as well as external experts during text legal expertise, faces several challenges.

Keywords: Hate Crime, Section 78 of the Criminal Law, Section 150 of the Criminal Law, Legal Expertise.

\section{Literatūra}

1. Kolčanovs, B., Zankovska-Odiṇa, S., Zālītis, K. Atšk,irīgs klients daudzveidīgā Latvijā. Rīga: Latvijas Cilvēktiesību centrs, 2010.

2. Kriminālā statistika. Latvijas Republikas Iekšlietu ministrijas Informācijas centrs. Iegūts no: http://www.ic.iem.gov.lv/node/109 [sk. 25.02.2016.].

3. Latviešu literārās valodas vārdnīca. 6. sējums, 2. daḷa. P-R. Rīga: Zinātne, 1987.

4. Naida noziegumi. Rìga: Latvijas Cilvēktiesību centrs, 2008. 
5. Treḷs, Ė. Sociālā naida un nesaticības izraisīšanas kritēriju noteikšana. Starptautiskā zinātniskā konference "Drošỉbas nostiprināšanas aktuālās problēmas: politiskie, sociālie, tiesiskie aspekti”: Programma un tēzes. Rīgā, 2015. gada 23. aprīlī. Rīga: Rīgas Stradiṇa universitāte, 2015. 97.-99. lpp.

6. Treḷs, Ė. Valsts policijas darbs daudznacionālajā sabiedrībā. Zinātniskā monogrāfija. Rīga: P\&K, 2012.

7. Ziņojums par Latviju (ceturtais posms). Strasbūra: Eiropas Komisija pret rasismu un neiecietību, 2012.

8. Starptautiskais pakts par pilsoṇu un politiskajām tiesībām. 16.12.1966. Starptautisks dokuments. Latvijas Vēstnesis, 61 (2826), 23.04.2003. Stājies spēkā 14.07.1992.

9. Cilvēka tiesību un pamatbrīvību aizsardzības konvencija. 04.11.1950. Starptautisks dokuments. Latvijas Vēstnesis, 143/144 (858/859), 13.06.1997. Stājies spēkā 27.06.1997.

10. Latvijas Republikas Satversme. 15.02.1922. Likums. Latvijas Vēstnesis, 43, 01.07.1993. Stājies spēkā 07.11.1922.

11. Grozījumi Krimināllikumā. 25.09.2014. Likums. Latvijas Vēstnesis, 204 (5264), 15.10.2014. Stājies spēkā 29.10.2014.

12. Krimināllikums. 17.06.1998. Likums. Latvijas Vēstnesis, 199/200 (1260/1261), 08.07.1998. Stājies spēkā 01.04.1999.

13. Kriminālprocesa likums. 21.04.2005. Likums. Latvijas Vēstnesis, 74 (3232), 11.05.2005. Stājies spēkā 01.10.2005.

14. Eiropas Cilvēktiesību tiesas 2006. gada 6. jūlija spriedums lietā Erbakans pret Turciju, iesniegums Nr. 59405/00.

15. Eiropas Cilvēktiesību tiesas 1998. gada 23. septembra spriedums lietā Leidjo un Izorni pret Franciju, iesniegums Nr. 24662/94.

16. Eiropas Cilvēktiesību tiesas 1976. gada 7. decembra spriedums lietā Hendisaids pret Apvienoto Karalisti, iesniegums Nr. 5493/72.

17. Latvijas Republikas Augstākās tiesas Senāta Krimināllietu departamenta 2010. gada 21. maija lēmums krimināllietā Nr. 11840001107, SKK-213/2010.

18. Latvijas Republikas Augstākās tiesas Krimināllietu tiesu palātas 2010. gada 22. februāra spriedums krimināllietā Nr. 11840001107, PAK-173/2010.

19. Rīgas apgabaltiesas Krimināllietu tiesu kolēgijas 2011. gada 8. jūnija spriedums krimināllietā Nr. 11840001410, Nr. K04-0184-11/28.

20. Rīgas apgabaltiesas Krimināllietu tiesas kolēgijas 2009. gada 20. oktobra spriedums krimināllietā Nr. 11840003809, K04-399-09/31.

21. Rīgas apgabaltiesas Krimināllietu tiesas kolēgijas 2008. gada 6. marta spriedums krimināllietā Nr. 11840001107, Nr. K04-0145-08/3.

22. Cēsu rajona tiesas 2014. gada 12. maija spriedums krimināllietā Nr. 11840003914, K11-0124-15.

23. Rīgas pilsētas Kurzemes rajona tiesas 2014. gada 17. decembra spriedums krimināllietā Nr. 11840001414, K28-0576-14/6.

24. Rīgas pilsētas Kurzemes rajona tiesas 2014. gada 22. janvāra spriedums krimināllietā Nr. 11840004913, K28-0168-14/2.

25. Rīgas pilsētas Kurzemes rajona tiesas 2012. gada 25. septembra spriedums krimināllietā Nr. 11840004211, K28-0523-12/9. 
26. Rīgas pilsētas Latgales priekšpilsētas tiesas 2013. gada 17. aprīḷa spriedums krimināllietā Nr. 11840000613, K29-1086/13.

27. Valmieras rajona tiesas 2014. gada 7. maija spriedums krimināllietā Nr. 11840003614, K39-0250/15.

28. Hate Crimes in the OSCE Region - Incidents and Responses. Annual Report for 2007. Warsaw: Organisation on Security and Cooperation in Europe, Office for Democratic Institutions and Human Rights, 2008.

29. Shibzuhov, Z. A. Publichnije prizivi k osushestvleniju terroristiceskoj dejatelnosti ili publichnoe opravdanije terorisma. Moskva: Jurlitinform, 2014. (Шибзухов, 3. А. Пубцичные призывы к осуществлению террористической Аеятельности ики публичное оправАание терроризма. Москва: Юрлитинформ, 2014.)

30. Shujskij, A. C. Otvetstvennostj za publicnije prizivi k osushestvleniju terroristiceskoj dejatelnosti ili publichnoe opravdanije terorisma. Aktualnije problemi ugolovnogo i ugolovnoispravitelnogo prava: sbornik nauchnix statej. Red. E. H. Zhelvakov. Moskva: Akademija Generalnoj prokuraturi RF, 2010. (Шуйский, А. С. Ответственность за публичные призывы к осуществлению террористической Аеятельности или пубцичное оправАание терроризма. Актуацьные проблемы уголовного и уголовно-исправительного права: сборник научных статей. РеА. Э. Н. Желваков. Москва: Академия Генерацьной прокуратуры РФ, 2010. С. 65-73.) 


\title{
Policijas darbinieku izglitīibas problēmas Latvijā
}

\author{
Dr. iur. Aleksandrs Matvejevs \\ Daugavpils Universitāte, Sociālo zinātṇu fakultāte, \\ Tiesību katedra, Latvija \\ aleksandrsmatvejevs5@inbox.lv
}

\section{Kopsavilkums}

Raksts veltīts kompleksai policijas apmācības organizatoriskā mehānisma izveides analīzei, lai izpētītu, apkopotu un apjaustu teorētiski tiesiskos Latvijas policijas funkcionēšanas jautājumus, kā arī kopējās stratēgijas attīstībai, kuras izstrādē tiek pārskatīta pašreizējā apmācības organizācija un norises stāvoklis. Pētījumā analizēts organizācijas nākotnes stāvoklis un tiek izstrādāti pārejas ceḷi no viena stāvokḷa uz otru.

Autors secina, ka ir nepieciešams izstrādāt un ieviest efektīvu policijas darbinieku profesionālās izglītības sistēmu saskaṇā ar mūsdienu demokrātiskas valsts, mūžizglītības koncepcijas un Boloṇas deklarācijas principiem, lai nodrošinātu kvalitatīvu policijas darbinieku sagatavošanu un veicinātu viṇu profesionālo meistarību.

Atslēgvārdi: izglītiba, policijas darbinieks, problēmas.

\section{levads}

Policijas darbinieku profesionālās augstākās izglìtības līmeṇa paaugstināšana ir viena no aktuālām problēmām. Šìs problēmas izpēte mūsdienu apstākḷos ir ḷoti svarīga un nepieciešama policijas darbības turpmākai pilnveidošanai.

Viens no aspektiem, kas norāda uz pētāmā jautājuma aktualitāti, ir tas, ka pēc Latvijas Policijas akadēmijas likvidācijas 2009. gada 31. decembrī [8] tika likvidēta valstī vienīgā augstskola, kura sagatavoja policijas darbiniekus otrā līmeṇa profesionālās augstākās izglīiỉbas studiju programmās.

Patlaban Latvijā tiek realizēta trīs līmeṇu izglìtības sistēma, kuras ietvaros policijas darbinieki iegūst profesionālo izglìtību un otrā līdz ceturtā līmeṇa profesionālo kvalifikāciju. Ceturtā līmeṇa profesionālo kvalifikāciju iegūst Valsts policijas koledžā pirmā 
līmeṇa profesionālās augstākās izglīitibas studiju programmā "Policijas darbs", kā arī kopš 2009. gada Daugavpils Universitātē pirmā līmeṇa profesionālās augstākās izglīitības studiju programmā "Civilā drošîba un aizsardzība". Piektā līmenna profesionālo kvalifikāciju iegūst Rīgas Stradiṇa universitātē otrā līmeṇa profesionālās augstākās izglìtības bakalaura studiju programmā "Tiesību zinātne".

Iekšlietu ministrijas sistēmas iestāžu un Ieslodzījuma vietu pārvaldes amatpersonu ar speciālajām dienesta pakāpēm dienesta gaitas likuma [3] pārejas noteikumu 8. punktā noteikts, ka līdz 2016. gada 1. jūlijam amatpersonas amatu var ieṇemt arī persona, kurai nav amata prasībām atbilstošas augstākās izglīīibas.

Deklarācijā par Māra Kučinska vadītā Ministru kabineta iecerēto darbību 87. punktā norādīts:

\footnotetext{
"[..] atbilstoši mūsdienu sabiedrības prasībām attīstīsim izmeklētāju un operatīvo darbinieku izglītības saturu un veicināsim attiecīgo studiju programmu pilnveidošanu, lai ar kvalificētu personālu nodrošinātu operatīvās darbības subjektus un iestādes ar kriminālprocesa veikšanas tiesībām, tai skaitā izveidosim Valsts policijas vecāko virsnieku otrā līmeṇa augstākās profesionālās izglîtības sistēmu atbilstoši jaunizveidotajam profesijas standartam." [1]
}

Iekšlietu ministrijas sistēmas iestāžu amatpersonu ar speciālajām dienesta pakāpēm profesionālās izglìīibas attīstības koncepcijā 2014.-2017. gadam norādīts, ka pēc vecākā virsnieka profesijas standarta izstrādes un apstiprināšanas tiks izvērtēta iespēja Valsts policijas vajadzībām ilgtermiṇa sadarbỉbas nolūkā pēc iepirkuma procedūras īstenošanas pasūtìt kādā no Latvijas augstskolām uz policijas darba specifiku orientētas otrā līmeṇa profesionālās augstākās izglīîibas studiju programmas izstrādi un speciālistu sagatavošanu studiju virzienā "Iekšējā drošîba un civilā aizsardzība" [4].

Policijas darbinieku augstākā profesionālā izglìtība, kurai jābūt balstìtai uz demokrātijas pamatvērtībām, tiesiskuma un cilvēktiesību aizsardzības, jāizstrādā saskaṇā ar policijas mērķiem [10]. Eiropas Padomes dokumentā - Ministru komitejas 2001. gada 19. septembra rekomendācijās par Eiropas policijas ètikas kodeksu [11] - mēǵināts iedibināt Eiropā vienotus principus un vadlīnijas attiecībā uz policijas vispārējiem mērḳiem, darbību un atbildību, nosakot, ka ar tiesībsargājošo funkciju un kārtības uzturēšanu (policijas galvenie mērḳi) demokrātiskā un tiesiskā sabiedrībā jāsaprot publiskā miera, likuma varas un kārtības uzturēšana sabiedrībā; indivīda pamattiesību un brīvību aizsargāšana un ievērošana; noziedzības novēršana un atklāšana; palīdzības sniegšana un kalpošana sabiedrïbai.

Policijas nākotne ir tieši atkarīga no to darbinieku profesionālās kvalifikācijas līmeņa, kuri tagad tiek pieņemti dienestā policijā. Normatīvajos aktos noteiktās vienveidīgās prasības pieņemšanai dienestā un atlases kritēriji liedz daudziem interesentiem iespēju sākt mācības un dienestu policijā. Jāṇem vērā ilgtermiṇa prognozes, kuras varētu ieviest negatīvas tendences uzṇemamo reflektantu kvantitatìvajā ìpatsvarā. Pēc Pasaules Bankas aplēsēm līdz 2025. gadam skolēnu skaits pamatskolās samazināsies par aptuveni $25 \%$, vidusskolās - par $20 \%$, bet vislielākais kritums sagaidāms augstākajā izglītībā, kur tiek prognozēta studentu skaita samazināšanās par 40\% [7]. 


\section{Materiāls un metodes}

Darba izpētes materiāls ir tiesību akti, kuri regulē policijas darbinieku izglītības jautājumus Latvijā. Rakstā galvenokārt izmantota vēsturiskā un salīdzinošā izpētes metode.

\section{Noteikumi par otrā līmeṇa profesionālās augstākās izglīiības valsts standartu}

Profesionālā augstākā izglītība - augstākās pakāpes profesionālā izglītība, kas dod iespēju iegūt ceturtā vai piektā līmeṇa profesionālo kvalifikāciju. Otrā līmeṇa profesionālā augstākā izglîtîba - augstākās pakāpes profesionālā izglìiība, kas dod iespēju iegūt piekto profesionālās kvalifikācijas līmeni.

Izglītības likuma [5] 32. panta pirmajā daḷā noteikts, ka valsts izglìtỉbas standarts ir dokuments, kas atbilstoši izglītības pakāpei, izglïtības veidam un mērkgrupai nosaka:

1) izglìtības programmu stratēgiskos mērḳus un galvenos uzdevumus;

2) izglìiības obligāto saturu;

3) izglìtojamā iegūtās izglīīibas vērtēšanas pamatprincipus un kārtību.

Savukārt panta otrā daļa paredz, ka valsts izglītības standarta ievērošana ir obligāta katrai juridiskajai un fiziskajai personai, kas izstrādā un īsteno attiecīgo izglìtības programmu.

Bakalaura programmas saturam ir jānodrošina zināšanu, prasmju un kompetences kopums atbilstoši Latvijas izglìīibas klasifikācijā noteiktajām ietvarstruktūras 6. līmeṇa zināšanām, prasmēm un kompetencei.

Ja bakalaura programmā imatrikulē studējošos ar iepriekš iegūtu pirmā līmen̦a profesionālo augstāko izglītîbu, tad bakalaura programmas saturu un apjomu, kā arī studiju kursu saturu un apjomu savstarpēji saskaņo. Atbilstošos pirmā līmeņa profesionālās augstākās izglītības programmās iegūtos kredītpunktus ieskaita bakalaura programmas apjomā.

Pēc bakalaura programmas apguves pieškiir profesionālo bakalaura grādu nozarē (profesionālās darbības jomā) un piektā līmeña profesionālo kvalifikāciju.

\section{Studiju virziens "lekšējā drošība un civilā aizsardzība”}

Latvijā studiju virzienā "Iekšējā drošîba un civilā aizsardzība" tiek realizētas Valsts policijas koledžā pirmā līmeṇa profesionālās augstākās izglītības studiju programma "Policijas darbs" un Daugavpils Universitātē pirmā līmeņa profesionālās augstākās izglītības studiju programma "Civilā drošība un aizsardzība".

Pēc Latvijas Policijas akadēmijas likvidācijas neviena Latvijas augstskola neuzṇem otrā līmeņa profesionālās augstākās izglìtības bakalaura studiju programmā, kurā varētu iegūt otrā lìmeṇa profesionālo augstāko izglìtību un piektā līmeṇa profesionālo 
kvalifikāciju policijas darbības jomā. Latvijas Universitāte sniedza iespēju Latvijas Policijas akadēmijas programmās studējošajiem pabeigt studijas un iegūt attiecīgo izglītîbu, bet neveica studentu uzñemšanu.

Saskaṇā ar Valsts policijas un Rīgas Stradiṇa universitāti noslēgto līgumu Valsts policijas vecāko virsnieku izglītošana tiek ìstenota Rīgas Stradiña universitātē otrā līmeṇa profesionālās augstākās izglītỉbas bakalaura studiju programmā "Tiesību zinātne", kurā iegūst profesionālo bakalaura grādu tiesību zinātnē un juriskonsulta profesionālo kvalifikāciju.

Lìdz ar vecākā virsnieka profesijas standarta pieņemšanu ir radusies nepieciešamība izstrādāt jaunu studiju programmu studiju virzienā "Iekšējā drošība un civilā aizsardzība", kas būtu pēctecīga Valsts policijas koledžas pirmā līmeṇa profesionālās augstākās izglītības studiju programmai "Policijas darbs" un Daugavpils Universitātes pirmā līmeña profesionālās augstākās izglìtības studiju programmai "Civilā drošība un aizsardzība”.

\section{Studiju programmas izstrāde}

Studiju programmas projekta izstrādi Daugavpils Universitātē veicināja Latgales reǵiona attīstības (dậejii arī Vidzemes un Zemgales reg̣ionu) intereses un policijas darbinieku profesionālās augstākās bakalaura izglīīibas nepieciešamība.

2015. gada 22. decembrī tika pieñemti Ministru kabineta noteikumi Nr. 794 "Grozijumi Ministru kabineta 2010. gada 18. maija noteikumos Nr. 461 "Noteikumi par Profesiju klasifikatoru, profesijai atbilstošiem pamatuzdevumiem un kvalifikācijas pamatprasībām un Profesiju klasifikatora lietošanas un aktualizēšanas kārtību"”, kuros ir iekḷauts policijas vecākā virsnieka profesijas standarts [9]. Nemot vērā pieṇemto profesijas standartu, Daugavpils Universitāte ir izstrādājusi studiju programmas projektu.

Izstrādātais studiju programmas projekts pilnībā atbilst Daugavpils Universitātes attīstības stratēgijai 2009.-2016. gadam [2], kura apstiprināta Senāta sēdē 2009. gada 10. jūlijā un kura paredz attīstīt universitāti kā akadēmiskajās tradīcijās balstītu, mūsdienīgu un konkurētspējīgu studiju, zinātnes un inovāciju centru galvenokārt Austrumlatvijas regionā.

Studiju programmas projekts izstrādāts, lai sagatavotu speciālistus, kuriem pēc bakalaura programmas apguves tiks pieškirts profesionālais bakalaura grāds nozarē (policijas darbības jomā) un piektā līmeṇa profesionālā kvalifikācija.

Studiju programmas projekta mērḳis ir sagatavot speciālistus Austrumlatvijas reǵionam: Valsts policijas Latgales reǵiona pārvaldei, daḷēji arī Zemgales reǵiona pārvaldei (Aizkraukles iecirknim, Jēkabpils iecirknim) un Vidzemes reǵiona pārvaldei (Gulbenes iecirknim, Madonas iecirknim), attiecīgo pašvaldību policijai, kā arī citu policijas institūciju teritoriālajām struktūrvienībām.

Daugavpils Universitāte plāno kopīgi ar Rīgas Stradiņa universitāti īstenot studiju programmu Rīgā attiecīgo speciālistu sagatavošanai Rīgai un pārējiem Latvijas reǵioniem. 
Studiju programmas projekta pamatā ir arī Latvijas Nacionālā attīstības plāna 2014.-2020. gadam nostādnes [6].

Latvijā faktiski nav specializētu bakalaura tipa profesionālo studiju programmu policijas amatpersonu augstākā līmeṇa profesionālajai sagatavošanai - Latvijas augstskolas dod izglītību tiesību jomā, bet tajās nav studiju kursu, kuri pilnveidotu zināšanas, iemaṇas un prasmi policijas darbā - īpaši kārtības policijas, kriminālpolicijas un pirmstiesas izmeklēšanas jomās.

Studiju programmas projekta modelis atbilst vienotās Eiropas izglīīibas telpas formai un saturam.

Tiek plānots, ka studijām programmā katru gadu imatrikulēs studentus, kuri ir ieguvuši pirmā līmeṇa profesionālo augstāko izglītību Latvijas Policijas akadēmijā laikposmā no 1993. līdz 2009. gadam, Valsts policijas koledžas pirmā līmeņa profesionālās augstākās izglìtības studiju programmā "Policijas darbs" un Daugavpils Universitātes pirmā līmeña profesionālās augstākās izglītības studiju programmā "Civilā drošība un aizsardzība".

\section{Kopsavilkums}

Ir jāizveido demokrātiskas un tiesiskas valsts doktrīnas. Lai efektīvi realizētu Latvijas policijas darbības modeli, kurš balstītos uz sabiedrības atbalstu un cilvēktiesību ievērošanu, kā arī uz dažādu kultūru un tradīciju respektēšanu, nepieciešama policijas darbinieku realizēta profesionālās augstākās izglîtības sistēma, kura tiktu veidota uz Boloṇas deklarācijas nostādnēm un mūžizglìtības koncepciju. Tādējādi

tiktu nodrošināts augsts profesionālisms, kas saskaṇā ar profesijas standartu atbilstu zināšanām, prasmēm un kompetencei.

Policijas darbinieku izglītība ietver procesu, kurā gūst zināšanas, apgūst prasmes un iemaņas, lai varētu veikt profesionālos uzdevumus. Izglitīibas mērḳis arī ir zināšanas, prasmes un domāšanas veids, bet to māca, galvenokārt attīstot domāšanu, izpratni, tas ir vairāk vērst uz problēmu risināšanu un analīzi.

Policijas darbinieku izglīiîbas sistēmas Eiropas Savienības dalībvalstīs parāda nepieciešamību praktiskā darba veicējiem sadarboties ar akadēmisko personālu, kā arī policijas darbiniekiem ar pētniekiem.

Daži uzskata, ka būtu jānošķir policijas apmācība no policijas izglīiības, sakot, ka policijas pētnieciskais darbs var brīvi attīstīties tikai tad, ja to veic zinātniski pētnieciskajos institūtos neatkarīgi no policijas. Citi aizstāv viedokli, ka jāintegrē policijas apmācība un izglītība, pārveidojot Eiropas Savienības nacionālās policijas akadēmijas par akreditētiem akadēmiskiem institūtiem augstskolu (universitātes) sistēmā, tādā veidā pozitīvo ietekmi, ko policijas pētỉjumi un augstākā izglìtỉba atstāj uz policijas organizāciju, padarot iespējami lielāku.

Otrā pieeja, kas saskan ar iepriekšminēto, ir izveidot Eiropas mēroga kopējas studiju programmas vadlīnijas policijas apmācībām un izglìtībai. 
Jāatzīst, ka Latvijā policijas darbinieku profesionālās augstākās izglìtỉbas sistēmas izveides problēmas, neapšaubāmi, ir plašākas, nekā tas ir atspoguḷots autora rakstā. Autors ieskicēja tikai tās profesionālās augstākās izglītības problēmas, kas radušās pēc vecākā virsnieka profesijas standarta pien,emšanas. Līdz ar profesijas standarta pieṇemšanu rodas nepieciešamība izstrādāt profesionālo augstāko bakalaura programmu studiju virzienā "Iekšèjā drošība un civilā aizsardzība".

Būtisks aspekts ir tas, ka nevar aprobežoties tikai ar patlaban nepieciešamo policijas darbinieku izglītošanu. Ir jādomā par nākotni, n,emot vērā pasaules globalizācijas procesus un Eiropas attīstības perspektīvas.

Autors secina, ka policijas darbinieku profesionālās augstākās izglīīibas sistēmas efektīva attīstība ir iespējama, tikai ieviešot kompleksu pieeju, kā arī uz organizatorisku, tiesisku un finansiāli ekonomisku pasākumu izstrādes un realizācijas pamata, turklāt tā ir tieši atkarīga no valsts izglìiības politikas, policijas profesionālās izglìiîbas normatīvi tiesiskās bāzes pilnveidošanas, mācību programmu standartizācijas un integrācijas.

\section{Problems in Education of Police Officers in Latvia}

\section{Abstract}

The article deals with the complex analysis of the organisational structure of police training, summarising and constructive critical comprehension of the theoretical law matters of the police activity in Latvia and also the transition of common strategy regarding the present condition of training and predicts the future condition of organisation so develops the ways of transfer from one condition to another.

Summarising it can be concluded that it is necessary to develop and implement effective professional education system for police officers pursuant to the principles of a contemporary democratic state and concept of lifelong education and Bologna Declaration that will provide for training of qualified police officers and promote their professionalism.

Keywords: education, police officers, problems.

\section{Literatūra}

1. Deklarācija par Māra Kučinska vadìtā Ministru kabineta iecerēto darbību. Rīga, 2016. gada februāris, 87. punkts. Iegūts no: http://www.pkc.gov.lv/images/vald\%C4\%ABbas deklar\%C4\%81cijas/2016/20160210_MKucinskis_vald_prior_GALA_VERS.pdf [sk. 19.03.2016.].

2. Daugavpils Universitātes attīstības stratēǵija 2009.-2016. gadam. Iegūts no: http://du.lv/ wp-content/uploads/2015/12/DU_strategija_kopsavilkums.pdf [sk. 19.03.2016.]. 
3. Iekšlietu ministrijas sistēmas iestāžu un Ieslodzījuma vietu pārvaldes amatpersonu ar speciālajām dienesta pakāpēm dienesta gaitas likums. Latvijas Vēstnesis, 101 (3469), 30.06.2006. Stājies spēkā 01.10.2006. Iegūts no: http://likumi.lv/doc.php?id=138750 [sk. 19.03.2016.].

4. Iekšlietu ministrijas sistēmas iestāžu amatpersonu ar speciālajām dienesta pakāpēm profesionālās izglìtības attīstības koncepcija 2014.-2017. gadam. Iegūts no: http://www.iem.gov.lv/ files/text/koncepcija(1).pdf [sk. 19.03.2016].

5. Izglītības likums. Latvijas Vēstnesis, 343/344 (1404/1405), 17.11.1998. Stājies spēkā 01.06.1999. Iegūts no: http://likumi.lv/doc.php?id=50759 [sk. 19.03.2016].

6. Latvijas Nacionālais attīstības plāns 2014.-2020. gadam. Latvijas Vēstnesis, 6 (4812), 09.01.2013. Stājies spēkā 20.12.2012. Iegūts no: http://likumi.lv/doc.php?id=253919 [sk.19.03.2016.].

7. Latvijas ilgtspējīgas attīstības stratēgija lìdz 2030. gadam. Latvija 2030, 2010.

8. Ministru kabineta 2009. gada 30. jūnija rīkojums Nr. 442 "Par Latvijas Policijas akadēmijas likvidāciju”. Latvijas Vēstnesis, 106 (4092), 08.07.2009. Stājies spēkā 30.06.2009. Iegūts no: http://likumi.lv/doc.php?id=194578 [sk. 19.03.2016.].

9. Ministru kabineta 2010. gada 18. maija noteikumi Nr. 461 "Par Profesiju klasifikatoru, profesijai atbilstošiem pamatuzdevumiem un kvalifikācijas pamatprasībām un Profesiju klasifikatora lietošanas un aktualizēšanas kārtību”. Latvijas Vēstnesis, 84 (4276), 28.05.2010. Stājies spēkā 01.06.2010., 2. pielikums. Iegūts no: http://likumi.lv/doc.php?id=210806 [sk. 19.03.2016.].

10. Oldersans, D. (Alderson J.) Cilvēktiesības un policija. Riga: LPA, 2004, 154. lpp.

11. The European Code of Police Ethics. Recommendation Rec (2001) 10 adopted by the Committee of Ministers of the Council of Europe on 19 September 2001 and explanatory memorandum. Strasbourg: Council of Europe Publishing, March 2002. Iegūts no: http://www.bak.gv.at/cms/ BAK_dt/download/downloads/files/Verhaltenskodex/CoE_FRA_RPT_2687_EN_500.pdf [sk.19.03. 2016.]. 


\title{
Nelikumīgas darbības iespējamie riski Latvijas apdrošināšanas nozarē
}

\author{
Jeḷena Alfejeva \\ Rìgas Stradiṇa universitāte, Juridiskā fakultāte, Latvija \\ alfejeva@inbox.lv
}

\section{Kopsavilkums}

Apdrošināšanas nozare kā valsts finanšu sistēmas sastāvdaļa, līdzīgi kā kredītiestāžu joma, satur reālu risku un nav pilnībā aizsargāta no iespējamām prettiesiskām darbībām ar noziedzīgi iegūtiem līdzekḷiem. Galvenokārt noziedzīgi līdzekḷi apdrošināšanas nozarē var tikt generēti ar apzināti nepamatotiem apdrošināšanas atlīdzību pieteikumiem, kurus apdrošinātāji nav spējīgi identificēt vai pierādìt pieteicēju krāpniecisko rīcību. Krāpnieciskā rīcība pret apdrošinātāju var izpausties kā apdrošināšanas objekta apzināta bojāšana, lai saṇemtu apdrošināšanas atlīdzību, vai kā pārspīlēta prasība naudas izteiksmē, vai arī kā apdrošināšanas gadījuma imitācija. Kaut arī dzīvības apdrošināšana pasaulē vairāk pakḷauta noziedzīgi iegūtu līdzekḷu legalizācijas riskam, Latvijas dzīiības apdrošināšanas nozarē šajā ziṇā aktivitāte nav vērojama. Savukārt nedzīvības apdrošināšanas joma ir vairāk pakḷauta krāpšanas riskam un daudz biežāk saskaras ar viltus pieteikumiem nekā dzīivibas apdrošināšanā. Latvijā līdz šim problēma nav aktualizēta un netika risināta pietiekamā līmenī.

Atslēgvārdi: apdrošināšana, krāpšana, noziedzīgi iegūtu līdzekḷu legalizācija.

\section{levads}

Apdrošināšana ir komercdarbības veids, kurš balstās uz risku vadību, nododot risku iestāšanās finansiālas sekas no vienas fiziskās vai juridiskās personas citai - specializētajam tiesību subjektam (komersantam) - apdrošinātājam (Apdrošināšanas un pārapdrošināšanas likuma 1. panta 9. punkts [1]. Apdrošināšana balstās uz sarežğìtajām līgumiska rakstura attiecībām starp apdrošinātāju, apdrošinājuma n,ēmēju, apdrošināto un apdrošināšanas starpnieku, lai mazinātu iespējamo notikumu (risku) iestāšanās negatīvās finansiālās sekas, kaut arī visas iespējamās risku iestāšanās finansiālās sekas apdrošinātais nevar novirzìt uz apdrošinātāju. 
Tiek prezumēts un ar tiesisko reglamentāciju kontrolēts, ka apdrošināšanai ir pozitĩvas sociālās sekas. N̦emot vērā apdrošināšanas nozares lielos apgrozỉjumus pasaulē, noziedzniekiem un noziedzīgiem grupējumiem vienmēr būs interese l̦aunprātīgi izmantot apdrošināšanu darījumus. Lielākā daḷa apdrošināšanas krāpšanu ir saistītas ar nepatiesiem vai nepamatoti palielinātiem prasījumiem. Apdrošināšanas krāpšanas ietekme îstermiṇā nav skaidri saskatāma, taču tā var izraisìt nopietnas negatīvas un pat bīstamas sekas sabiedrībai ilgtermiñā.

No valsts ekonomikas tiek izṇemti līdzekḷi, kuri varētu tikt ieguldìti tautsaimniecībā, un tas ilgtermiṇā smagi ietekmē finanšu integritāti un stabilitāti. Finanšu darījumu darba grupa (FATF), kas ir neatkarīga starpvaldību organizācija, kas izstrādā un sekmē politiskās nostādnes pasaules finanšu sistēmas aizsardzībai pret noziedzīgi iegūtu līdzekḷu legalizāciju, terorisma finansēšanu un masu iznīcināšanas ieroču izplatīšanas finansēšanu, atzīmē, ka apdrošināšanas krāpšanas jāizskauž apdrošināšanas sabiedrībām, izmantojot risku vadỉbas un iekšējās kontroles politiku [11].

Latvijas Apdrošinātāju asociācija publiskajā vidē apgalvo, ka izkrāpto apdrošināšanas atlīdzību apjoms Latvijā ir vidēji 10\% no visām izmaksātajām atlīdzībām. Tas nozīmē, ka vairāki miljoni eiro, ko apdrošinātājiem maksā to klienti, tiek izmaksāti par nepatiesiem apdrošināšanas gadījumiem un tādējādi nonāk pie krāpniekiem.

\section{Darba mērḳis, materiāls un metodes}

Raksta mērḳis ir definēt apdrošināšanas krāpšanas rādīto risku noziedzīgi iegūtu līdzekḷu legalizācijas kontekstā, noteikt tās bīstamību un ieskicēt Latvijā pastāvošās problēmas saistībā ar to.

Pētījuma teorētiskā bāze ir Latvijas un citu valstu zinātnieku atzinumi, normatīvā bāze ir Latvijas un ārvalstu tiesību regulējums saistībā ar noziedzīgi iegūtu līdzekḷu legalizācijas riskiem un krāpšanu apdrošināšanas nozarē. Raksta izstrādē izmantota analīzes un sintēzes metode, zinātniskās indukcijas un dedukcijas metode, kā arī salīdzinošā metode.

\section{Rezultāti}

\section{Vispārējs situācijas raksturojums apdrošināšanas nozarē noziedzīgi iegūtu līdzekḷu legalizācijas kontekstā}

N̦emot vērā, ka apdrošināšanas komercdarbỉba nodrošina risku iestāšanās negatīvo finansiālo seku novēršanu, izmantojot iepriekš saṇemto apdrošināšanas prēmiju uzkrājumus, tā ir ḷoti neaizsargāta pret krāpnieciskiem darījumiem un arī pret noziedzīgi iegūto līdzekḷu legalizāciju. 
Saṇemot līdzekḷus no apdrošinātāja par viltus apdrošināšanas gadỉjumu, likumpārkāpējs tādējādi šos līdzekḷus var izmantot kā legālus, un prettiesiski iegūtie līdzekḷi pārvēršas par likumīgu aktīvu.

Saistībā ar problēmjautājumiem apdrošināšanas nozarē Finanšu darījumu darba grupa (FATF) iekḷāva apdrošināšanu risku zonā [11].

\section{Apdrošināšanas nozare Latvijā}

Kaut arī Latvijas apdrošināšanas darījumu tirgus ir salīdzinoši mazs, tā apgrozỉjuma pieauguma tempi ir ievērojami, salīdzinot ar citām Eiropas valstīm. Šobrīd apdrošināšanas tirgus pēc apdrošināšanas prēmiju apgrozījuma ir aptuveni 1,5\% no IKP [21, 22, 23]. Latvijā 2015. gadā darbojās astoṇas valstī reǵistrētas apdrošināšanas sabiedrības (6 nedzīvības un 2 dzīvības) un 14 ārvalstu apdrošināšanas sabiedrību (10 nedzīiības un 4 dzīvības) filiāles. Latvijā līdz šim brīdim nav reǵistrēta neviena pārapdrošināšanas sabiedrība.

Atbilstoši Noziedzīgi iegūtu līdzekḷu legalizācijas un terorisma finansēšanas novēršanas likuma [3] normām par šã likuma subjektiem ir uzskatāmi arī dzīivības apdrošināšanas komersanti, kā arī apdrošināšanas starpnieki, kuri sniedz dzīvības apdrošināšanas starpniecības pakalpojumus.

Minētajiem likuma subjektiem jāizveido un jādokumentē, izstrādājot attiecīgas politikas un procedūras, savam darbības veidam atbilstošu noziedzīgi iegūtu līdzekḷu legalizācijas un terorisma finansēšanas novēršanas iekšējā kontroles sistēma, kas ir pasākumu kopums, kas ietver darbības likuma prasību izpildes nodrošināšanai, paredzot tam atbilstošus resursus un veicot darbinieku apmācību, lai pēc iespējas novērstu likuma subjekta iesaistīšanu noziedzīgi iegūtu līdzekḷu legalizācijā vai terorisma finansēšanā.

Tomēr Noziedzīgi iegūtu līdzekḷu legalizācijas novēršanas dienesta 2014. gada Ziṇojums [25] un šā dienesta vadītāja publiski sniegtā informācija par 2015. gadu [26] liecina, ka apdrošināšanas sabiedrības un apdrošināšanas starpnieki nav aktīvi ziṇotāji par klientu aizdomīgiem un neparastiem darïjumiem.

Turklāt, ṇemot vērā, ka nedzīvības apdrošināšanas sabiedrības nav Noziedzīgi iegūtu līdzekḷu legalizācijas un terorisma finansēšanas novēršanas likuma subjekti, par krāpnieciskiem atlīdzības prasījumiem nedzīvības apdrošināšanā informācija vispār netiek apkopota.

Apdrošināšanas komercdarbību uzrauga specializēta valsts institūcija Finanšu un kapitāla tirgus komisija, kura uz minētā likuma pamata izdod uzraudzībā esošajām iestādēm saistošos normatīvos noteikumus.

2015. gada 23. decembrī tika pieņemti Finanšu un kapitāla tirgus komisijas normatīvie noteikumi Nr. 234 "Klientu padziḷinātās izpētes normatīvie noteikumi kredìtiestādēm un licencētām maksājumu un elektroniskās naudas iestādēm”, kas izdoti saskaṇā ar Noziedzīgi iegūtu līdzekḷu legalizācijas un terorisma finansēšanas novēršanas likuma 7. panta otro dalı,u, 22. panta piekto daḷu un 47. panta otro daḷu. Kaut arī 
šajos noteikumos ir lietots termins "finanšu iestāde", 2. punktā skaidri norādīts, ka tie ir saistoši tikai kredītiestādēm un licencētām maksājumu iestādēm, un elektroniskās naudas iestādēm, kā arī to filiālēm.

Arī 2016. gada 27. janvārī pieṇemtie Finanšu un kapitāla tirgus komisijas normatīvie noteikumi Nr. 25 "Noziedzīgi iegūtu līdzekḷu legalizācijas un terorisma finansēšanas riska pārvaldīšanas normatīvie noteikumi” [4], kas izdoti saskaṇā ar noteikumos Nr. 234 minēto delegeējumu un arī saskaṇā ar Kredītiestāžu likuma $34 .^{2}$ panta ceturto dalıu, attiecas tikai uz kredītiestādēm.

2008. gada 27. augustā pieṇemtie Finanšu un kapitāla tirgus komisijas normatīvie noteikumi Nr. 125 "Klientu padziḷinātās izpētes normatīvie noteikumi” [5] atbilstoši 1 . punktā norādìtajam ir saistoši privātajiem pensiju fondiem, ieguldījumu brokeru sabiedrībām, ieguldījumu pārvaldes sabiedrībām, registrētām maksājumu iestādēm un elektroniskās naudas iestādēm, kuru darbībai nav nepieciešama licence.

Tādējādi apdrošinātājiem un apdrošināšanas starpniekiem specificētas prasības noziedzīgi iegūtu līdzekḷu legalizācijas un terorisma finansēšanas riska pārvaldīšanai valsts nav noteikusi.

\section{Krāpšana un noziedzīgi iegūto līdzek!̣u legalizēšana apdrošināšanā}

Apdrošinātāji savā darbībā saskaras gan ar klientu krāpšanu, kuru var atbalstīt iesaistīti apdrošināšanas starpnieki, kā arī pat apdrošinātāja darbinieki.

Krāpšanu apdrošināšanā raksturo tas, ka krāpnieks mērḳtiecīgi cenšas iegūt no apdrošinātāja saistībā ar tā profesionālo darbību nepamatotu labumu. Krāpšana apdrošināšanā var izpausties kā viltus apdrošināšanas atlīdzības pieprasỉjums, balstoties uz dažādiem faktiskiem apstākḷiem, kas šādu pieprasijumu pamato (apdrošināšanas objekta apzināta bojāšana, lai saṇemtu apdrošināšanas atlīdzību, pārspīlēta prasība naudas izteiksmē, apdrošināšanas gadījuma imitācija, kā arī vienkārši maldināšana par negadījuma apstākḷiem).

Krāpšanā var tikt iesaistīti apdrošināšanas starpnieki, finanšu konsultanti, apdrošinot neesošu apdrošinājuma n̦ēmēju vai objektu, slēdzot līgumu ar atpakaḷejošu datumu vai sniedzot nepatiesu informāciju riska vērtēšanai.

Ekspertu komiteja noziedzīgi iegūtu līdzekḷu legalizēšanas apkarošanas pasākumu un terorisma finansēěanas novērtējumam MONEYVAL konsekventi pievērš uzmanību apdrošināšanas sektoram, norādot, ka ir svarīgi pievērsties krāpšanas darījumu apkarošanai tajā, it īpaši ņemot vērā nozares specifiku [16].

Apdrošināšanas nozare tradicionāli tiek uzskatīta par nozari, kam ir zema aizsargātība pret nelegāli iegūtu līdzekḷu legalizēšanas un teroristu finansēšanas riskiem. Galvenais sektors noziedzīgu fondu legalizācijai ir banku sistēma, tomēr pēc arvien sarežğîtāku kontroles mehānismu ieviešanas bankas sektorā noziedznieki meklē alternatīvus variantus, kā legalizēt noziedzīgi iegūtos līdzekḷus. Tādējādi šiem mērḳiem arvien vairāk tiek izmantota apdrošināšanas nozare un citi nebanku finanšu produkti. 
Vairākās pasaules valstīs ir paredzētas specializētas vadlīnijas aizdomīgu darījumu identificēšanai apdrošināšanas sektorā.

Ir daži vispārīgi faktori apdrošināšanas nozarē, kas padara to jutīgu pret nelegāli iegūtu līdzekḷu legalizēšanu:

1) izpratnes trūkums - pastāv vispārējs izpratnes trūkums par to, ka apdrošināšanas produkti var būt pievilcīgi noziedzniekiem kā līdzeklis nelegāli iegūtu līdzekḷ lu legalizēšanai. Šì problēma pastāv visos līmeṇos: apdrošinātājiem, apdrošināšanas starpniekiem, regulatoriem un tiesībaizsardzības iestādēm;

2) nespēja identificēt nelegāli iegūtu līdzekḷu legalizēšanas darījumus - balstās uz izpratnes trūkumu un nozīmē, ka nelegāli iegūtu līdzekḷu legalizēšanas gadījumi bieži tiek ignorēti. Nespēja identificēt aizdomīgus darījumus ir saistìta ar vairākiem faktoriem:

- ir nepietiekama datu apmaiṇa par klientu aizdomīgām darbībām apdrošināšanas nozarē;

- pastāv vispārējas nelegāli iegūtu līdzekḷu legalizēšanas apkarošanas uzraudzības problēmas, jo īpaši vispārējās apdrošināšanas un pārapdrošināšanas nozarē;

- pārapdrošināšanas tirgus starptautiskais raksturs apgrūtina visu apdrošināšanas darījumu aspektu atklāšanu;

- apdrošināšanas nozare galvenokārt ir neaizsargāta pret nelegāli iegūtu līdzekḷu legalizēěanu;

3) uzmanības pievēršana tikai liela apmēra krāpšanai - kaut gan liela apmēra krāpšanas atklāšana un novēršana ir būtiska apdrošinātājiem, tā bieži tiek uzskatìta par vienīgo draudu veidu;

4) uzkrājumu un ieguldījumu iespējas - daudzi dzīvības apdrošināšanas un pensiju produkti ir ietaupijumu un ieguldijjumu elementi, kas nozīmē, ka attiecīgie produkti balstās uz reālu vērtību, kas savukārt nozīmē, ka tie var tikt izmantoti kā nodrošinājums aizdevumiem, radot iespaidu par līdzekḷiem no šķietami likumīga avota. Daudzi ievainojamïbas aspekti ir saistīti ar šiem produktiem, jo tie ir līdzīgi FATF tipologiskajos ziņojumos noteiktajiem;

5) naudas noguldījumi - iedzīvotājiem novecojot, daudzas valstis cenšas veicināt uzkrājumu shēmas, tostarp dzīvības apdrošināšanas un pensiju produktus. Tie ir īpaši pakḷauti nelegāli iegūtu līdzekḷu legalizēšanas riskam;

6) starpnieku pakalpojumu izmantošana - daudzi apdrošinātāji pārdot savus produktus, izmantojot neatkarīgu starpnieku pakalpojumus, kuri nav ieinteresēti apdrošināšanas darījuma finansiālajā rezultātā.

Kaut arī apdrošināšanas nozare atrodas zem vispārējas valsts uzraudzības, tomēr tā ir pakḷauta krāpšanas un nelegāli iegūtu līdzekḷ lu legalizēšanas riskam, kura mērī̌sanai šobrīd sabiedrība nepievērš būtisku uzmanību. Diemžēl valsts ievieš tikai vairāk formālu prasību nozarei bez atbilstošas detalizācijas pakāpes. 


\section{Dzīvības apdrošināšanas pakḷaušana nelegāli iegūtu līdzekḷu legalizēšanas riskam}

Dzīvības apdrošināšanas nozare aptver plašu produktu klāstu - no riska apdrošināšanas, kas saistīti ar nāves iestāšanos, līdz uzkrājumu un ieguldījumu produktiem ar dzīvības apdrošināšanas elementu. Šādi produkti, funkcijas un darbỉbas, kas saistītas ar dzīvības apdrošināšanu, nav aizsargāti pret nelegāli iegūtu līdzekḷ legalizēšanas un terorisma finansēšanas risku, balstoties uz turpmāk minēto:

1) prēmijas izmaksā katru gadu vai ar vienreizējiem maksājumiem virs nepieciešamās summas vai veicot papildu maksājumus virs summas, kurai sākotnēji piekrita;

2) iemaksas pārsniedz ierasto vai līgumā paredzēto ieguldījumu;

3) personas prēmijas izmaksā par vairākām nesaistītām apdrošinātajām personām;

4) dzīvības apdrošināšanas polises tiek izmantotas kā nodrošinājums kredītam;

5) produkti, kas paredz uzteikuma termiṇus un iespēju saṇemt atpakal iemaksāto prēmiju;

6) tiesības uz visu vai daḷu no kompensācijas izmanto persona, kas nav cietušais (labuma piešķiršana nesaistitajai personai);

7) apdrošināšanas līgums tiek izbeigts, lai iemaksu saņemtu pirms termiña;

8) dzīvības apdrošināšanas polises ir ar iespēju iegādāties ieguldījumu fondu vienības, turklāt tajās nav nekādu naudas summas ierobežojumu;

9) dzīvības apdrošināšanas polises ir ar augstu uzkrājumu procentu.

Situācija saistībā ar nelegāli iegūtu līdzekḷu legalizāciju trešā līmeṇa pensiju jomā ir līdzīga tam, kāda tā ir saistībā ar dzīvības apdrošināšanas polisēm, lai gan ir dažas unikālas iezīmes. Trešajam pensiju līmenim ir ḷoti līdzīgs riska profils kā dzīvības apdrošināšanas produktiem.

FATF rekomendācijas [11] paredz veikt klienta izpētes pasākumus attiecībā uz dzīvības apdrošināšanas polišu saṇēmējiem līdz līmenim, kad reālais saṇēmējs vai saṇēmēji ir identificēti pilnībā, pārbaudot to izmaksas brīdī. Dzīivibas apdrošināšanas polises saṇēmējs ir jānorāda kā attiecīgais riska faktors, un, ja viṇu nav iespējams identificēt, darỉjums ir jāreǵistrē kā aizdomīgs.

FATF rekomendācijas ar mazāku detalizācijas pakāpi ir pārṇemti Noziedzīgi iegūtu līdzekḷu legalizācijas un terorisma finansēšanas novēršanas likuma normās.

\section{Nedzīvības apdrošināšanas pak!̣aušana krāpšanas riskam}

Kaut arī nedzīvības apdrošināšanas nozare ir mazāk riskanta no nelegāli iegūtu līdzekḷu legalizācijas aspekta kā dzīvības apdrošināšana, tomēr tā ir būtiski pakḷauta krāpšanas riskam, izvirzot viltus prasījumus apdrošināšanas atlīdzības izmaksai (nedzīvības apdrošināšanas veidi, no kuriem katrs ir atsevišḳi licencējams, ir norādīti Apdrošināšanas un pārapdrošināšanas likuma 19. pantā). 
Ir vairāki faktori, kas ierobežo nelegāli iegūtu līdzekḷ legalizēšanas risku nedzīvības apdrošināšanā $[11,24]$, piemēram:

1) atlikušo vērtību trūkums - nedzīvības apdrošināšanas līgumi darbojas uz noteiktu laiku, parasti uz vienu gadu vai īsāku termiṇu, un, beidzoties līguma termiṇam, nekādi papildu norēḳini netiek veikti, proti, parasti nav atlikušās vērtības, kuru varētu pieprasit;

2) kompensācijas princips - apdrošinātajam ir jābūt apdrošināmā interesei, apdrošinātājam riskam reāli jāiestājas, turklāt izmaksājamā atlīdzība sedz tikai reāli nodarìtos zaudējumus;

3) izmeklēšana par pieteiktajām prasībām - apdrošinātāji parasti veic padziḷinātu izpēti par samērā lielām prasībām, lai aizsargātu sevi pret krāpšanu;

4) lēns maksājums - salīdzinot ar banku un vērtspapīru nozarēm, nav paātrināti norēķinu noteikumi, t. i., maksājumu sistēmas ir salīdzinoši lēnas;

5) sarežǵitiiba - daži apdrošināšanas produkti ir sarežğìit, tāpēc to tehniskās iespējas un noteikumi bieži vien nav skaidri personām, kas nav iesaistītas apdrošināšanas nozarē, lai gan jāuzsver, ka šo sarežgitīîbu var izmantot tieši krāpnieki, lai veiktu nelegāli iegūtu līdzekḷu legalizēšanas darījumus.

Tomēr ir faktori, kas padara nedzīvības apdrošināšanas nozari pievilcīgu krāpniekiem un, iespējams, arī nelegāli iegūtu līdzekḷu legalizētājiem, proti:

1) trūkst izpratnes par risku - turklāt nedzīvības apdrošināšana nav pakḷauta obligātajai kontrolei attiecībā uz nelegāli iegūtu līdzekḷu legalizēšanu un terorisma finansēšanu;

2) starptautiskā darbības joma - nedzīvības apdrošināšanas sektors ir daudz atvērtāks starptautiskajai komercdarbībai nekā dzīvības apdrošināšanas sektors. Dažu risku (piemēram, kravas apdrošināšanā) būtība nozīmē, ka prasības var rasties dažādās jurisdikcijās. Turklāt ievērojams parakstāmā riska apjoms prasa iesaistīt citas jurisdikcijas pārapdrošināšanu;

3) starpnieki - daudzi apdrošinātāji piedāvā tirgū savus produktus ar neatkarīgu starpnieku līdzdalību, tāpēc krāpšanas risks ir lielāks; izplatīšanas tīkli var būt gari un sarežgìiti, iesaistot virkni starpnieku no dažādām jurisdikcijām; starpnieki var saṇemt būtiskas komisijas procentos no prēmijām; sākotnējās attiecībās ar klientu stājas starpnieks, kaut arī atbildību no apdrošināšanas līguma uzñemas apdrošinātājs;

4) apdrošināšanas aizsardzības spēkā stāšanās - bieži ir nepieciešams, lai apdrošināšanas aizsardzība stātos spēkā nekavējoties vai īsi pēc līguma dokumentu noformēšanas, apdrošināšanas periods var būt samērā îss, tāpēc nav laika veikt klienta padziḷināto izpēti; turklāt augstākās pakāpes labticības princips nosaka, ka apdrošinātājs var paḷauties uz klienta sniegto informāciju, slēdzot apdrošināšanas līgumu, un izmeklēšana tiks veikta pēc apdrošināšanas gadījuma pieteikšanas, kas var būt par pamatu apdrošināšanas atlīdzības maksājumam; 
5) apdrošināšanas atlīdzības izmaksa trešajām personām - tas tā ir vienmēr civiltiesiskās atbildības apdrošināšanā, kur apdrošinātājam ir pienākums izmaksāt apdrošināšanas atlīdzību cietušajam, kā arī citos apdrošināšanas veidos atlīdzības var tikt izmaksātas remontētājiem, zaudējumu regulētājiem un citām personām, kas nav saistītas ar apdrošināšanas līgumu;

6) plaši pazīstami un izplatīti apdrošināšanas produkti - to nosaka dažu apdrošināšanas veidu obligātums, piemēram, sauszemes transportlīdzekḷu ìpašnieku civiltiesiskās atbildības apdrošināšana, kas nozīmē, ka noziedznieki varētu vairāk zināt par šādiem apdrošināšanas produktiem nekā, piemēram, par ieguldījumu produktiem.

Starptautiska apdrošināšanas uzraudzības asociācija Pasaules Bankas 2006. gada pētỉjumā [24] norāda, ka nedzìīibas apdrošināšanā nelegāli iegūtu līdzekḷu legalizēšana pārstāvēta ar viltotiem prasījumiem. Nepatiesi pieteikumi rodas, ja nelegāli iegūtu līdzekḷ̣u legalizētāji iegādājas likumīgus ỉpašumus un pēc tam ar l̦aunprātīgu dedzināšanu vai citiem lïdzekḷiem rada viltus prasības, lai atgūtu dạı no saviem ieguldỉjumiem.

Tomēr Latvijā ir vērojamas problēmas ar krāpšanas bīstamības novērtēšanu, kā arī ar pašu šādu gadījumu identificēšanu un kriminālsoda piemērošanu par noziedzīgiem nodarījumiem, nepatiesi pieprasot apdrošināšanas atlīdzību. Sabiedriskā doma nepatiesas informācijas sniegšanu apdrošinātājiem attaisno, tādējādi pēc būtības atbalstot krāpšanu nedzīvības apdrošināšanā. Turklāt sabiedrības attieksme pret apdrošinātājiem kopumā ir negatīva, kas varbūt ir saistìta ar to, ka apdrošinātāji, veicot klientu sniegtās informācijas pārbaudi par potenciāliem apdrošināšanas gadījumiem, dažkārt tur aizdomās arī labticīgos klientus, kā arī atsevišḳ,os gadījumos nemaksā apdrošināšanas atlīdzību nepamatotu aizdomu dēlı.

Latvijas iedzīvotāji neuzskata, ka apdrošināšanas krāpšana ir problēma, kas ir jārisina sabiedrībai. Liela dạ̦a sabiedrības pat uzskata, ka apdrošinātāja mānī̌̌ana nav pelnījusi krimināltiesisku sodu. Apdrošināšanas krāpšana tiek uzskatīta tikai un vienīgi par apdrošinātāju problēmu, savukārt apdrošinātāju līdzekḷi tiek uztverti nevis kā klientu iemaksātie līdzekḷi (fonda princips), bet kā neierobežots un neidentificējams avots, no kura naudas sañemšana jebkuru iemeslu dēl ir attaisnojama.

Bieži kriminālprocesi par atklātiem apdrošināšanas krāpšanas gadijumiem vai nu netiek uzsākti vispār, vai arī tiek izbeigti, trūkstot pierādījumiem vai iestājoties noilgumam. Tāpēc apdrošinātāji nav ieinteresēti ziṇot par atklātiem krāpšanas gadījumiem policijai, iesniedzot pieteikumu kriminālprocesa uzsākšanai, bet aprobežojas ar apdrošināšanas atlīdzības izmaksas atteikumu, balstoties uz formāliem apsvērumiem (nepatiesas informācijas sniegšana). Tādējādi krāpnieku kriminālvajāšana bieži vien netiek veikta vispār un viṇi netiek sodīti.

Tiesnešu izpratne par apdrošināšanas krāpšanu ir atškirīiga, un vienveidīga tiesu prakse apdrošināšanas krāpšanas lietās nepastāv. 
Pēdējos gados tiesā izskatītas visai maz krimināllietu saistībā ar krāpšanu pret apdrošinātājiem (kasācijas kārtībā trīs gadu laikā izskatìtas tikai divas tādas lietas). Tā krimināllietā Nr. 11094107911 [17] kasācijas instance ir atcēlusi apelācijas instances tiesas spriedumu, ar kuru divas personas ir atzìtas par vainīgām un sodītas par to, ka grupā pēc iepriekšèjas vienošanās mēgināja ar viltu iegūt svešu mantu (krāpšana), kas izpaudās kā viltus apdrošināšanas pieteikuma iesniegšana par transportlīdzekḷa bojājumiem, kurš ne tīši sabojāts pie citiem apstākḷiem, nevis pie apdrošināšanas pieteikumā norādītajiem, un par ko apdrošināšanas atlīdzība saskaṇā ar līgumu nepienākas. Tomēr apdrošinātājs, konstatējot pieteicēju noziedzīgu rīcību, atteicās izmaksāt apdrošināšanas atlīdzību. Personu darbības kvalificētas pēc Krimināllikuma 15. panta ceturtās daḷas un 177. panta otrās dalias.

Šajā lēmumā var uzskatāmi redzēt vairākas ar krāpšanu apdrošināšanā saistītas problēmas:

1) kvalifikācijas problēma, ņemot vērā, ka Krimināllikumā apdrošināšanas krāpšana (178. pants) ir nodalīta no citiem krāpšanas veidiem (177. pants). Tomēr 178. panta dispozīcijas neiekḷauj tādas personas darbības kā viltus pieteikuma iesniegšanu, ja manta, par kuras bojājumiem persona pretendē uz apdrošināšanas atlīdzības saṇemšanu, ir bojāta neapzināti, bet apstākḷos, kuri izslēdz apdrošināšanas atlīdzības saṇemšanu (līdzīga problēma konstatējama, ja ar nolūku saṇemt atlīdzību apzināti bojātā manta pieder, piemēram, līzinga sabiedrībai vai cita veida kreditoram). Tādas darbības būtu jākvalificē kā krāpšana pēc Krimināllikuma 177. panta (ko, piemēram, pilnībā neizprot apsūdzēto advokāts);

2) apsūdzēto advokāts tiesai pauž viedokli, kas gan atbilst sabiedrības priekšstatiem par apdrošināšanu un krāpšanu saistībā ar to, gan arī norāda uz būtisku problēmu izpratnē par apdrošināšanu principā, proti, ka likuma "Par apdrošināšanas līgumu" 21. panta trešā daḷa garantē, ka informācijas pazin̄ošana - arī viltus apdrošināšanas pieteikums - nerada krimināltiesisko atbildỉbu. Pēc advokāta domām, strīdi par apdrošināšanas jautājumiem būtu skatāmi civiltiesiskā kārtībā (tiesa gan pareizi norāda, ka civiltiesiskā atbildība un krimināltiesiskā atbildība ir patstāvīgi juridiskās atbildības veidi. Kriminālatbildība var iestāties arī par civiltiesisku deliktu, ja tā kaitīguma pakāpe sasniedz kriminālatbildības nosacījumus);

3) sankcija pēc Krimināllikuma 178. panta ir vieglāka, bet noziegums tiek pabeigts ar pieteikuma iesniegšanu apdrošinātājam, toties krāpšanas mēǵinājums (pieteikuma iesniegšana apdrošinātājam) pēc Krimināllikuma 177. panta pirmās daḷas nav krimināli sodāma rīcība. Tādējādi materiālo zaudējumu apmēra konstatēšanai ir būtiska nozīme, jo no mantiskā zaudējuma apmēra var būt atkarīgs kriminālprocesa uzsākšanas pamatojums - ne tikai izvēloties starp Krimināllikuma 180. pantu vai 177. pantu, bet arī izlemjot, vai 
viltus pieteikuma iesniegšana ir krimināli sodāma darbība vispār (mēǵinājums pēc Krimināllikuma177. panta pirmās dạlas nav sodāms). Tas nozīmē, ka Krimināllikuma normas nav sistēmiski sakārtotas.

Arī otrajā lietā Nr. 11240026712 [18], kur gan problēmu klāsts ir ievērojami šaurāks, ir strīds par apsūdzētā darbību kvalifikāciju saskaṇā ar Krimināllikuma 178. pantu, kuru gan kasācijas instances tiesa atrisina ar atziṇu, ka "abu instanču tiesām neradās nekādas šaubas par apsūdzētā /A.S./ vainīgumu Krimināllikuma 178. panta pirmajā daḷā paredzētā noziedzīgā nodarījuma izdarī̌anā", tātad tādu nav arī kasācijas instances tiesai

Kaut arī daži zinātnieki un praktiḳi uz šìm problēmām ir norādījuši jau sen, līdz šim likumdevējs nav izrādījis vēlmi šo jautājumu sakārtot.

\section{Secinājumi}

1. Apdrošināšanas jomā no nelikumīgu darbību novēršanas aspekta ir problēmas, kuru risināšanai netiek pievērsta pienācīga uzmanība. Turklāt dzīvības un nedzīvības apdrošināšanas pakḷaušana naudas legalizēšanas riskam atškiras un prasa specifisku pieeju.

2. Apdrošināšanas krāpšanas problēmas risināšanā liela loma ir tiesībsargājošām institūcijām, kurām būtu jārīkojas aktīvāk un profesionālāk. Sabiedrībai ir jāzina, ka valsts nodrošina vainīgo personu saukšanu pie atbildỉbas un krāpniekiem arī apdrošināšanas jomā nenovēršami tiks piemērotas kriminālas sankcijas.

3. Ir būtiski nodrošināt, lai tiesnešiem ir pietiekama kompetence apdrošināšanas jautājumos. Tiesnešu apmācības centram attiecīgi būtu jāiekḷauj programmā apmācības par apdrošināšanas jautājumiem, apdrošināšanu regulējošo tiesību normu mērḳiem, to starptautisko regulējumu un praksi, kā arī Latvijā spēkā esošo tiesību normu iespējamām interpretācijām starptautiskā regulējuma kontekstā.

4. Valsts policijai jāplāno policistu apmācība apdrošināšanas jautājumos saistībā ar apdrošināšanas tiesisko reglamentāciju un veicamiem pasākumiem noziedzīgu nodarījumu izmeklēšanai finanšu jomā.

5. Apdrošināšanas krāpšanas krimināltiesiskais regulējums Latvijā ir nepilnīgs un ir būtiski jālabo. Kriminālajām sankcijām jābūt tādām, lai tās atturētu potenciālos krāpniekus no krāpniecisko darbību veikšanas.

6. Jāpārdomā Krimināllikuma 178. panta redakcija, kā arī Krimināllikuma papildināšana ar noziedzīga nodarījuma sastāvu, kurš iekḷautu sevī viltus apdrošināšanas pieteikuma iesniegšanu, kad bojājumi mantai, par kuru nepamatoti, sniedzot nepatiesu informāciju par bojāšanas apstākḷiem, ir pieteikta apdrošināšanas atlīdzība, nav radīti šīs mantas īpašnieka apzinātu darbību dēl nolūkā saṇemt apdrošināšanas atlīdzību. 


\section{Possible Risks of Illegal Activities in Latvian Insurance Sector}

\section{Abstract}

The insurance industry as a part of national financial system the same as credit institutions contains a real risk and is not fully protected from possible illegal activities with the proceeds of crime. In the insurance sector, mainly criminal funds can be generated by deliberately unreasonable insurance claims that insurers are not able to identify or prove the applicant's fraudulent conduct. Fraudulent action against the insurer may take the form of insurance object damaging for obtaining insurance reimbursement, as well as by exaggerated requirement in terms of money and imitation of insurance cases. While the life insurance in the world is more exposed to money laundering risks, there is no activity in this regard in Latvian life insurance sector. By contrast, non-life insurance sphere is more exposed to the risk of fraud and more often confronted with false claims than life insurance. In Latvia, the problem not yet actuated and adequately solved.

Keywords: insurance, fraud, money laundering.

\section{Izmantotā literatūra un avoti}

\section{Tiesību akti}

1. Apdrošināšanas un pārapdrošināšanas likums. Latvijas Vēstnesis, 124 (5442), 30.06.2015.

2. Latvijas Republikas Krimināllikums. Latvijas Vēstnesis, 199/200 (1260/1261), 08.07.1998.; Ziñotājs, 15, 04.08.1998.

3. Noziedzīgi iegūtu līdzekḷu legalizācijas un terorisma finansēšanas novēršanas likums. Latvijas Vēstnesis, 116 (3900), 30.07.2008.; Ziñotājs, 16, 28.08.2008.

4. Finanšu un kapitāla tirgus komisijas normatīvie noteikumi Nr. 25: Noziedzīgi iegūtu lïdzekḷu legalizācijas un terorisma finansēšanas riska pārvaldīšanas normatīvie noteikumi. Latvijas Vēstnesis, 22 (5594), 02.02.2016.

5. Finanšu un kapitāla tirgus komisijas normatīvie noteikumi Nr. 125: Klientu padziḷinātās izpētes normatīie noteikumi. Latvijas Vēstnesis, 135 (3919), 02.09.2008.

\section{Literatūra}

6. Acharya, Suman. Money Laundering (ML) and Terrorism Financing (TF) in the Insurance Market: A Risk and Vulnerability (May 10, 2015). Iegūts no: SSRN: http://ssrn.com/ abstract=2604560 vai http://dx.doi.org/10.2139/ssrn.2604560

7. Agayeva, Svetlana. Examining Anti-Bribery and Corruption Measures in a Single Framework to Combat Money Laundering and Terrorist Financing (2014). Iegūts no: http://www.acams. org/aml-white-paper-anti-bribery-corruption 
Jeḷena Alfejeva. Nelikumīgas darbības iespējamie riski Latvijas apdrošināšanas nozarē

8. Anderson, Judy Feldman \& Brown, Robert L. (2005). Risk and Insurance. The Society of Actuaries, USA.

9. Association of Certified Fraud Examiners (2014). Global Fraud Study. Report to the Nations on the Occupational Fraud and Abuse.

10. Elnagdy, Sam Adam. How to Choose an Effective and Sufficient Sample for an AML Program Audit. ACAMS, USA.

11. FATF Report on the Risk Based Approach Guidance for the Life Insurance Sector (October 2009).

12. International Association of Insurance Supervisors (May 2007). Report on the Survey on Preventing, Detecting and Remedying Fraud in Insurance.

13. International Association of Insurance Supervisors (October 2004). Guidance Paper No. 5 on Anti Money Laundering and Combating the Financing of Terrorism.

14. International Association of Insurance Supervisors (October 2013). Application Paper on Combating Money Laundering and Terrorism Financing.

15. International Association of Insurance Supervisors (September 2011). Application Paper on Deterring, Detecting, Reporting and Remedying Fraud in Insurance.

16. MONEYVAL (2010). Money Laundering through Private Pension Funds and the Insurance Sector. Adopted by MONEYVAL at its $33^{\text {rd }}$ Plenary Meeting. Strasbourg, 27 September 1 October 2010.

\section{Tiesu prakse}

17. 2015. gada 30. septembra Latvijas Republikas Augstākās tiesas lēmums Lietā Nr. 11094107911. Lietas arhiva Nr. SKK-J-0339-15.

18. 2014. gada 4. septembra Latvijas Republikas Augstākās tiesas lēmums Lietā Nr. 11240026712. Lietas arhīva Nr. SKK-0506-14.

\section{Citi materiāli}

19. Seminārs Deloitte "Fraud investigation", Rīga, 25.08.2010., lektora Dana Bicana (Dan Bican) sagatavotie prezentāciju materiāli.

20. The Financial Times Lexicon. The Financial Times; Cadbury, Adrian, Report of the Committee on the Financial Aspects of Corporate Governance, Gee, London, December, 1992, p. 15. COM/2012/0740

21. OECD (2003). Apdrošināšanas statistikas gadagrāmata 1994-2001, p. 2; "Sigma Insurance Research Paper 8”, World Insurance in 2002, p. 26. Iegūts no: http://ssrn.com/ abstract $=2604560$

22. Statistics No. 50. European Insurance in Figures, December 2014. Iegūts no: http://www. insuran ceeurope.eu/sites/default/files/attachments/StatisticsNo50EuropeanInsurancein Figures.pdf

23. European Insurance - Key Facts, August 2015. Iegūts no: http://www.insuranceeurope. eu/sites/default/files/attachments/European\%20Insurance\%20-\%20Key\%20Facts\%20-\%20 August\%202015.pdf 
24. World Bank (2006). ICP 28: Anti-Money Laundering and Combating the Financing of Terrorism Basic-level Module. Iegūts no: http://www.iaisweb.org/modules/cciais/assets/ files/pdf/061002_ICP_28__Anti-Money_Laundering_and_Combating_the_Financing_of_ Terrorism.pdf

25. Noziedzīgi iegūtu līdzekḷu legalizācijas novēršanas dienesta 2014. gada ziṇojums. Iegūts no: http://www.prokuratura.gov.lv/upload_file/Faili/Kontoles_dienests/KD\%202014g_atskaite1. pdf

26. Kontroles dienesta vadītājs: Bankas l̦oti aktīvi ziṇo par aizdomīgiem darījumiem. Iegūts no: https://www.db.lv/finanses/bankas/kontroles-dienesta-vaditajs-bankas-loti-aktivi-zinopar-aizdomigiem-darijumiem-44,4704 


\title{
Tiesību pārsūdzēt lēmumu realizācijas problemātika procesā par noziedzigi iegūtu mantu
}

\author{
Juris Stukäns \\ Rigas Stradina universitäte, \\ Juridiskā fakultāte, Latvija \\ juris.stukans@tiesas.lv
}

\section{Kopsavilkums}

Rakstā ir aplūkota procesā par noziedzīgi iegūtu mantu iesaistīto personu savu tiesību uz mantu realizācijas problemātika. Darba izstrādes gaitā tika analizēts procesā par noziedzīgi iegūtu mantu iesaistīto personu tiesību realizācijas kriminālprocesuālais regulējums, kā arī Latvijas starptautiskās saistības nodrošināt personu tiesības uz mantu realizāciju noziedzīgi iegūtu līdzekḷu konfiskācijas gadījumā. Pētījuma rezultātā tiek atzīts, ka procesa par noziedzịgi iegūtu mantu kriminālprocesuālais regulējums ir nepilnīgs, neskaidrs un piel̦auj iespēju atšķirīgi interpretēt tiesību normas, kas iekḷautas Kriminālprocesa likuma 59. nodaḷā - "Process par noziedzīgi iegūtu mantu".

Atslēgvārdi: process par noziedzīgi iegūtu mantu, tiesības pārsūdzēt lēmumu, procesa par noziedzīgi iegūtu mantu dalībnieki.

\section{levads}

2016. gadā Latvijas valdība apṇēmusies pabeigt sarunas par iestāšanos Ekonomiskās sadarbības un attīstības organizācijā (Organisation for Economic Co-operation and Development - OECD). OECD ir 1961. gadā dibināta starpvaldību organizācija, kas apvieno 34 attīstītākās pasaules valstis, tai skaitā arī 21 ES dalỉbvalsti. OECD definē, ka tās misija ir demokrātijas un tirgus ekonomikas principu ievērošanas veicināšana, kā arī valstu ilgtspējīgas tautsaimniecības attīstības sekmēšana globalizācijas kontekstā [5]. OECD eksperti norāda, ka Latvijai nepieciešams uzrādīt progresu jautājumā par noziedzīgi iegūtu līdzekḷu legalizācijas novēršanu Kukuḷošanas apkarošanas starptautiskajos 
Juris Stukāns. Tiesību pārsūdzēt lēmumu realizācijas problemātika procesā par noziedzīgi iegūtu mantu

biznesa darījumos darba grupai. Iepriekš minētais norāda, ka Latvijā vēl nav izdarīts viss iespējamais, kas nodrošinātu efektīvu noziedzīgi iegūtu līdzekḷu legalizācijas novēršanu un cīnu pret noziedzīgi iegūtu līdzekḷu legalizāciju.

Latvijas Republikas Satversmes 105. pantā noteikts, ka īpašuma tiesības var ierobežot vienīgi saskaṇā ar likumu, savukārt 92. pantā teikts, ka ikviens var aizstāvēt savas tiesības un likumiskās intereses taisnīgā tiesā. Iepriekš minētais likumdevējam uzliek par pienākumu pieņemt tādu normatīvo regulējumu, kas nodrošina ikviena tiesību aizsardzību un likumisku interešu realizāciju īpašuma tiesību aizskaršanas gadījumā. Procesa par noziedzīgi iegūtu mantu mērḳis ir mantisko jautājumu savlaicīga atrisināšana, pieņemot, ka pierādijumu kopums dod pamatu uzskatît, ka mantai, kura izņemta vai kurai uzlikts arests, ir noziedzīga izcelsme vai saistība ar noziedzīgu nodarījumu. Tāpēc ikvienam, kurš uzskata, ka process par noziedzịgi iegūtu mantu aizskar viṇa intereses, jānodrošina iespēja savas tiesības un likumiskās intereses aizstāvēt taisnīgā tiesā.

\section{Darba mērķis}

Izvērtēt tiesību pārsūdzēt rajona (pilsētas) tiesas lēmumu realizācijas iespējas kriminālprocesuālo regulējumu procesā par noziedzīgi iegūtu mantu.

\section{Materiāls un metodes}

Darba izstrādes laikā tika analizēts vēsturiskais un spēkā esošais kriminālprocesuālais regulējums, pielietota tiesību normu vēsturiskā, sistēmiskā, teleologiiskā un gramatiskā interpretācijas metode, kā arī informācijas apkopošanas, sistematizācijas un analīzes izpētes metode.

\section{Diskusija}

Kriminālprocesa likuma 627. panta otrās daḷas 2. punktā noteikts, ka lēmumā uzsākt procesu par noziedzīgi iegūtu mantu procesa virzìtājs norāda, kuras personas ir saistìtas ar konkrēto mantu, tas ir, mantu, kura ir saistìta ar noziedzīgu nodarïumu vai kurai ir noziedzīga izcelsme. Savukārt Kriminālprocesa likuma 628. pants, norādot, kuras personas ir jāinformē par procesa par noziedzīgi iegūtu mantu uzsākšanu, paredz, ka lēmuma kopiju par procesa par noziedzīgi iegūtu mantu uzsākšanu nekavējoties ir jānosūta aizdomās turētajam vai apsūdzētajam un personai, pie kuras manta tika izṇemta vai tai tika uzlikts arests, ja šādas personas attiecīgajā kriminālprocesā ir, vai arī citai personai, kurai ir tiesības uz konkrēto mantu.

No iepriekš minētā izriet, ka ar mantu saistītas personas ir:

- aizdomās turētais vai apsūdzētais;

- persona, pie kuras manta tika izñemta vai tai tika uzlikts arests;

- cita persona, kurai ir tiesības uz konkrēto mantu. 
Juris Stukāns. Tiesību pārsūdzēt lēmumu realizācijas problemātika procesā par noziedzīgi iegūtu mantu

Kriminālprocesa likuma 628. pantā arī noteiktas iepriekš minēto personu tiesības:

- personiski vai ar aizstāvja vai pārstāvja starpniecību piedalīties procesā par noziedzīgi iegūtu mantu;

- mutvārdos vai rakstveidā tiesā izteikt savu attieksmi pret pieṇemto lēmumu;

- iesniegt tiesai pieteikumus.

Tomēr Kriminālprocesa likuma 628. pantā nav paredzēts, ka iepriekš minētās personas var iesniegt sūdzỉbu par tiesas lēmumu.

Salïdzinot procesa par noziedzīgi iegūtu mantu kriminālprocesuālo regulējumu ar kriminālprocesā iesaistīto personu vispārīgiem noteikumiem, ir pamats atzìt, ka gadījumos, kad personai ir tiesības pārsūdzēt rīcību vai nolēmumu, tas tiek norādìts pie konkrētās personas tiesībām. Tāpēc nav skaidrs, kāpēc procesā par noziedzīgi iegūtu mantu personām nav noteikts, ka tās var pārsūdzēt tiesas lēmumu. Arī salīdzinot ar regulējumu par personas, kurai ir tiesības uz aizstāvību, pamattiesībām, Kriminālprocesa likuma $60 .^{2}$ panta pirmās dal̦as 9. punktā noteikts, ka personai, kurai ir tiesības uz aizstāvību, ir tiesības likumā noteiktajos gadījumos, termiṇos un kārtībā pārsūdzēt procesuālos lēmumus. Novērtējot vispārīgo kriminālprocesuālo regulējumu par tiesībām iesniegt sūdzību, tas ir, saskaņā ar Kriminālprocesa likuma 336. panta pirmo dal̦u sūdzību par kriminālprocesu veicošās amatpersonas rīcību vai nolēmumu var iesniegt procesā iesaistītā persona, kā arī persona, kuras tiesības un likumīgās intereses ir aizskartas ar konkrēto rīcību vai nolēmumu, ir pamats atzīt, ka regulējums nav attiecināms uz procesu par noziedzīgi iegūtu mantu. Tiesai, izskatot procesu par noziedzīgi iegūtu mantu, nav pilnvaru konkrētajā kriminālprocesā, jo no konkrētā kriminālprocesa tiek izdalīti materiāli, lai izlemtu kriminālprocesā radušos mantisko jautājumu, kā arì tiesa nav procesa virzītājs, jo kriminālprocesā turpinās izmeklēšana un kriminālprocess paliek iestādē.

Kriminālprocesa likuma 631. panta pirmajā daḷā noteikts, ka tiesas lēmumu 10 dienu laikā var pārsūdzēt apgabaltiesā, sūdzību vai protestu iesniedzot rajona (pilsētas) tiesā. Minētā norma paredz tiesības pārsūdzēt rajona (pilsētas) tiesas lēmumu, bet nenosaka, kuras personas to var izdarìt. Var pieñemt, ka tiesas lēmumu var pārsūdzēt personas, kuras ir saistītas ar mantu, bet tomēr ir pamats jautājumam - kāpēc tas nav noteikts pie personu tiesībām, n̦emot vērā arī citu kriminālprocesā iesaistīto personu tiesību regulējuma principus. Tāpēc ir pamats atzìt, ka regulējums par tiesībām pārsūdzēt rajona (pilsētas) tiesas lēmumu nav precīzs un pięlauj dažādas interpretācijas.

Kriminālprocesa likuma $111 .{ }^{1}$ pants paredz kriminālprocesā iesaistītās personas statusu kā kriminālprocesā aizskartam mantas īpašniekam. Vai šāds kriminālprocesuālais statuss ir personām, kuras iesaistìtas procesā par noziedzīgi iegūtu mantu? No Kriminālprocesa likuma $111 .^{1}$ panta pirmās daḷas izriet, ka kriminālprocesā aizskartais mantas īpašnieks ir îpašnieks vai likumīgais valdītājs, kura tiesības rīkoties ar mantu procesuālo darbību rezultātā ir ierobežotas vai atṇemtas, un ja šai personai nav Kriminālprocesa likumā noteikto tiesību uz aizstāvību. 
Juris Stukāns. Tiesību pārsūdzēt lēmumu realizācijas problemātika procesā par noziedzīgi iegūtu mantu

Tātad procesā par noziedzīgi iegūtu mantu ir tiesības piedalīties personai, kurai ir tiesības uz konkrēto mantu, bet kriminālprocesā var būt iesaistītā persona - īpašnieks vai likumīgais valdītājs, kura tiesības rīkoties ar mantu procesuālo darbību rezultātā ir ierobežotas vai atṇemtas. No iepriekš minētā var secināt, ka procesā par noziedzīgi iegūtu mantu var piedalīties plašāks personu loks, jo tiesības piedalīties netiek ierobežotas ar īpašuma vai valdījuma tiesībām. Tātad Kriminālprocesa likumā ir divi atšḳirīgi regulējumi par personām, kuras var piedalīties procesā par noziedzīgi iegūtu mantu, un personām, kuru tiesības rīkoties ar mantu procesuālo darbību rezultātā ir ierobežotas vai atnemtas.

Interesants ir arī fakts, ka kriminālprocesā aizskartā mantas īpašnieka tiesības atšḳiras no procesā par noziedzīgi iegūtu mantu iesaistīto personu tiesībām.

Kriminālprocesa likuma 111. ${ }^{1}$ panta pirmajā daḷā noteikts, ka mantas īpašniekam vai likumīgajam valdītājam personiski vai ar pārstāvja starpniecību ir šādas tiesības:

1) mutvārdos vai rakstveidā izteikt savu attieksmi pret pieṇemtajiem lēmumiem attiecībā uz mantu;

2) iesniegt pieteikumus vai sūdzības par amatpersonu rīcību vai lēmumiem attiecībā uz mantu;

3) juridiskās palīdzības saṇemšanai uzaicināt advokātu.

Tāpat Kriminālprocesa likuma 111 . $^{1}$ panta otrajā dạ̦ā noteikts, ka mantas īpašniekam ir pienākums pēc procesa virzìtāja pieprasỉjuma rakstveidā paziṇot savu sūtījumu saṇemšanas pasta vai elektronisko adresi un par tās maiṇu, ar ko kriminālprocesā aizskartais mantas īpašnieks apṇemas 24 stundu laikā saṇemt kriminālprocesu veicošās amatpersonas nosūtītos sūtījumus un bez kavēšanās ierasties pēc procesa virzītāja uzaicinājuma vai izpildìt citus minētos kriminālprocesuālos pienākumus.

Personai, kura ir iesaistīta procesā par noziedzịgi iegūtu mantu, Kriminālprocesa likumā pienākumi nav noteikti.

Salīdzinot personas, kura ir iesaistīta procesā par noziedzīgi iegūtu mantu, tiesību regulējumu ar aizskartā mantas īpašnieka tiesību regulējumu, nav saprotams, kāpēc ir atšḳirīgs regulējums un vai tam bija un ir pamatojums. Nemot vērā iepriekš izklāstīto un izvērtējot tiesību normas, ir pamats atzìt, ka ir nepieciešami likuma grozījumi, lai novērstu neprecizitātes un nepilnības.

Kriminālprocesa likumā arī nav noregulēts, pēc kādiem kritērijiem procesa virzītājs procesā par noziedzīgi iegūtu mantu nosaka personu, kurai ir tiesības uz konkrēto mantu. Arī tiesu prakse dod pamatu secināt, ka procesa virzìtājiem, kā arī tiesai nav skaidrības par to, kādām personām ir tiesības piedalīties procesā par noziedzīgi iegūtu mantu. Piemēram, kad tiek arestēts konts bankā, par procesu par noziedzīgi iegūtu mantu un par tiesas sēdi tiek paziņots bankai. Lietā tiek aicināts bankas pārstāvis, bet vai tam ir pamatojums, un vai banka, kas sniedz konkrētai personai pakalpojumu, atbilstoši Kriminālprocesa likumā noteiktajam ir persona, pie kuras manta tika izṇemta vai tai uzlikts arests, vai tomēr tā ir konta îpašnieks. 
Juris Stukāns. Tiesību pārsūdzēt lēmumu realizācijas problemātika procesā par noziedzīgi iegūtu mantu

N̦emot vērā iepriekš izklāstīto, ir pamats secināt, ka būtu nepieciešams sakārtot regulējumu, lai tiesības pārsūdzēt tiesas lēmumu būtu noteiktas skaidri un precīzi, nepieļaujot to apšaubī̌̌anu vai dažādu interpretāciju. Ir jānodrošina, lai likumā konsekventi tiktu lietoti termini. Kriminālprocesa likumā terminu pielietojums nav sakārtots, konsekvents un saskaņots. Vienā normatīvajā aktā jāpielieto vieni un tie paši principi, veidojot tiesību normas, izn,emot gadijumus, kad atšḳirīgai pieejai ir pamatojums un tādējādi arī izskaidrojums. Normatīvā akta teksta neskaidrība kalpo par pamatu atzinumam, ka tiesību realizācija tiek ierobežota.

Regulējums nav precīzs arī gadījumā, kad procesa virzîājs nav personai paziṇojis par savu lēmumu saistībā ar konkrēto mantu, bet persona uzskata, ka tai ir tiesības uz konkrēto mantu, un vēlas iesaistīties procesā, kad materiāli ir jau tiesā.

Uz personas, kurai ir tiesības uz konkrēto mantu, procesuālo garantiju nepietiekamību tika norādìts jau 2010. gada decembrī profesores Ā. Meikališas un profesores K. Stradas-Rozenbergas veiktajā pētijumā "Mantas konfiskācijas tiesiskais regulējums Latvijā un Eiropas Savienībā, tās izpildes mehānisma efektivitātes nodrošināšana". Tajā minēts, ka joprojām aktuāls ir jautājums par iesaistīto personu nepietiekamo procesuālo garantiju sistēmu, jo KPL norādītās šo personu tiesības nevar atzīt par atbilstošām efektīvai tiesību aizsardzībai; noteikti, ka šīm personām neatkarīgi no to procesuālā statusa būtu jābūt tiesībām pašām piedalìties procesā un saṇemt juridisko palīdzību (nevis pašām vai ar kāda starpniecību), kā arī tiesībām izteikt pretargumentus uz pieñēmumu par tām piederošas mantas noziedzīgo izcelsmi, tostarp iesniegt pierādījumus [8].

Latvijas Republikas Saeima 2011. gada 8. jūlijā pieṇēma likumu "Grozījumi Kriminālprocesa likumā” [6], kas stājās spēkā 2011. gada 11. augustā, papildinot Kriminālprocesa likuma 629. pantu ar piekto daḷu, kā arī 629. panta trešajā daḷā svītroja vārdus "un pārbauda iesniegtos pierādījumus" un ceturtajā dạ̦ā vārdus "piedalīties pierādỉjumu pārbaudē". Kriminālprocesa likuma 629. pants regulē tiesas procesu par noziedzīgi iegūtu mantu, nosakot tiesneša rīcību, saṇemot lietu par noziedzīgi iegūtu mantu, un tiesas sēdes gaitu. Kriminālprocesa likuma 629. panta piektā daḷa tika izteikta šādā redakcijā: "Procesa par noziedzīgi iegūtu mantu lietā esošie materiāli ir izmeklēšanas noslēpums, un ar tiem drīkst iepazìties procesa virzìtājs, prokurors un tiesa, kas izskata šo lietu. Šã likuma 628. pantā minētās personas ar lietā esošajiem materiāliem var iepazīties ar procesa virzìtāja aț̦auju un viṇa noteiktajā apjomā."

Iepriekšminētos grozījumus skarbi raksturoja zvērināts advokāts E. Rusanovs, norādot, ka "visbeidzot - trekna svìtra būtiskiem taisnīgas tiesas elementiem tika pārvilkta pāri ar KPL grozījumiem, kas stājās spēkā 2011. gada 11. augustā..” [9].

Jāatzīst, ka ir pamats uzdot jautājumu, vai šāds regulējums, ierobežojot personas tiesības iepazīties ar lietā esošiem materiāliem, nodrošina personai iespēju pilnvērtīgi realizēt savas pārsūdzības tiesības.

Iepriekš minēto priekšlikumu grozìt Kriminālprocesa likuma 629. pantu pēc likumprojekta izskatî̌̌anas otrajā lasijumā kā priekšlikumu iesniedza Tieslietu ministrija. Tieslietu ministrija kā pamatojumu vēstulē norādīja, ka praksē ir atšķirīga izpratne 
Juris Stukāns. Tiesību pārsūdzēt lēmumu realizācijas problemātika procesā par noziedzīgi iegūtu mantu

par to, vai procesa par noziedzīgi iegūtu mantu materiāli ir uzskatāmi par izmeklēšanas noslēpumu. Kā argumentu tā norādīja, ka izmeklēšanas iestādes izvairās uzsākt un sūtìt uz tiesu procesus par noziedzīgi iegūtu mantu, jo ar materiāliem var iepazìties personas, kuras var būt arī aizdomās turētās personas pamata kriminālprocesā, no kura izdalīti materiāli, bet pirmstiesas izmeklēšana tiek turpināta. Tādējādi var tikt apdraudēta kriminālprocesa sekmīga izmeklēšana [7].

Rodas jautājums, vai var atzīt par pamatotu argumentu, ka izmeklěšanas intereses tiek pretstatìtas personas interesēm aizstāvēt savas tiesības uz mantu. Ir jāṇem vērā svarīgs nosacījums, ka procesu par mantas atzīšanu par noziedzīgi iegūtu var uzsākt lielākoties tikai tad, kad objektīvu iemeslu dēl krimināllietas nodošana tiesai drīzumā (saprātīgā laikposmā) nav iespējama. Tādējādi kriminālprocess jau tiek izmeklēts un tuvojas beigām personas tiesību ierobežošanas termiṇi pirmstiesas kriminālprocesā. Turklāt Kriminālprocesa likumā noteikts, ka, izbeidzoties pirmstiesas kriminālprocesa termin,iem, pirmstiesas kriminālprocess pret personu jāpabeidz vai jāatcel visi ierobežojumi. Tāpēc ir pamats atzìt, ka likums paredz termiṇus, kuros procesa virzìtājam būtu jāsavāc un jānostiprina pietiekami daudz pierādījumu, lai izlemtu jautājumu par personas saukšanu pie kriminālatbildības. Nemot vērā iepriekš minēto, ir pamats apšaubīt, vai izmeklēšanas noslēpums var kalpot par pamatojumu turpināt ierobežot personai tiesības zināt pierādījumus, uz kuriem balstās secinājumi par mantas noziedzīgu izcelsmi vai saistību ar noziedzīgu nodarījumu. Ir jāṇem vērā arī otrs nosacỉjums, kad var uzsākt procesu par noziedzịgi iegūtu mantu, proti, pierādījumu kopums dod pamatu uzskatìt, ka mantai, kura izn,emta vai kurai uzlikts arests, ir noziedzīga izcelsme vai saistība ar noziedzīgu nodarījumu. Tātad, uzsākot procesu par noziedzīgi iegūtu mantu, izslēdzot visas sapratīgās šaubas, ir pierādīts, ka manta ir noziedzịgi iegūta. Tāpēc personām vairs nav iespēju ietekmēt jau iegūtos un nostiprinātos pierādījumus. Vērtējot jautājumu par tiesību ierobežošanu iepazīties ar pierādījumiem, ir jāṇem vērā, ka jautājums par mantas atzīšanu par noziedzīgi iegūtu tiek izlemts galīgi un šobrīd likums neparedz šo jautājumu pārskatīt, ņemot vērā kriminālprocesa pabeigšanas veidu un rezultātu (piemēram, kriminālprocess tiek izbeigts, atzīstot, ka nav noticis noziedzīgs nodarījums).

Šobrīd tiek sagatavoti Kriminālprocesa likuma grozījumi, lai nodrošinātu Eiropas Parlamenta un Padomes 2014. gada 3. aprīḷa Direktīvas 2014/42/ES par nozieguma rīku un noziedzīgi iegūtu līdzekḷu iesaldēšanu un konfiskāciju Eiropas Savienībā, kas stājās spēkā 2014. gada 19. maijā un kuras saskaṇā ar Direktīvas 12. pantu ieviešanas termiṇš ir 2016. gada 4. oktobris, prasību ieviešanu Latvijas kriminālprocesuālajā regulējumā [1]. Minētais Kriminālprocesa likuma projekts ir pieejams Ministru kabineta interneta mājas lapā, jo jau 2015. gada 16. jūlijā likumprojekts tika izsludināts Valsts sekretāru sanāksmē. Diemžēl zvērināts advokāts E. Rusanovs 2016. gada 5. janvāra žurnālā "Jurista Vārds" publicētajā rakstā "Procesa par noziedzīgi iegūtu mantu regulējums Kriminālprocesa likumā" norādīja, ka šobrīd Tieslietu ministrijas attiecīgajā darba grupā teju slepeni notiek rosīgs darbs, lai realizētu vērienīgu šì procesa reformu, kas, protams, kārtējo reizi novedis jau pie tik ikdienišşi pierastajiem KPL [Kriminālprocesa likuma] grozijumiem [9]. 
Juris Stukāns. Tiesību pārsūdzēt lēmumu realizācijas problemātika procesā par noziedzīgi iegūtu mantu

Iepazīstoties ar likumprojektu, ir konstatējams, ka netiek mainīts regulējums attiecībā uz procesa par noziedzīgi iegūtu mantu dalībniekiem un viṇu tiesībām, kā arī tiesībām lietas dalībniekiem iepazìties ar procesa par noziedzīgi iegūtu mantu materiāliem.

Latvijai saistošie starptautiskie tiesību akti nosaka pienākumu nodrošināt personai, kuras intereses skar process par noziedzīgi iegūtu mantu, iespēju efektīvi aizstāvēt savas intereses. Eiropas Padomes konvencijas par noziedzīgi iegūtu līdzekḷu legalizācijas un terorisma finansēšanas novēršanu, kā arī šo līdzekḷu meklēšanu, izṇemšanu un konfiskāciju (Varšavas konvencija) 8. pantā noteikts, ka ikviena dalībvalsts pieṇem tādus normatīvos un cita veida aktus, kas var būt nepieciešami, lai nodrošinātu to, ka ieinteresētajām personām, kuras ietekmē 3., 4. un 5. pantā minētie pasākumi un citi attiecīgie šīs sadaḷas noteikumi, ir pieejami efektīvi tiesiskās aizsardzības līdzekḷi, lai aizsargātu šo personu tiesības [2]. Konvencijas 3. pants paredz konfiskācijas pasākumus, 4. pants paredz izmeklēšanas pasākumus un pagaidu pasākumus un 5. pants - ĩpašuma iesaldēšanu, izṇemšanu un konfiskāciju.

Eiropas Padomes konvencijas par noziedzīgi iegūtu līdzekḷu legalizācijas novēršanu, meklēšanu un izņemšanu 5. pantā noteikts, ka ikviena puse veic tādus likumdošanas un cita veida pasākumus, kādi nepieciešami, lai ieinteresētajām personām, uz kurām attiecas 2. un 3. pantā minētie pasākumi, tiek nodrošināta efektīva to tiesību juridiskā aizsardzība [3]. Konvencijas 2. pants paredz konfiskācijas pasākumus un 3. pants - izmeklēšanas pasākumus un pagaidu pasākumus.

Eiropas Savienības Padomes Pamatlēmuma 2005/212/TI (2005. gada 24. februāris) par noziedzīgi iegūtu līdzekḷu, nozieguma rīku un īpašuma konfiskāciju 4. pantā noteikts, ka ikviena dalībvalsts veic pasākumus, kas vajadzīgi, lai ieinteresētajām pusēm, ko skar 2. (konfiskācija) un 3. pantā (paplašinātas konfiskācijas pilnvaras) paredzētie pasākumi, nodrošinātu efektīvus tiesiskās aizsardzības līdzekḷus, lai sargātu to tiesības [4].

Eiropas Parlamenta un Padomes 2014. gada 3. aprịla Direktīvas 2014/42/ES 8. pantā (par aizsargpasākumiem) noteikts, ka dalībvalstis veic nepieciešamos pasākumus, kuru mērḳis ir nodrošināt personām, kuras skar šajā direktīvā noteiktie pasākumi, tiesības uz efektīviem aizsardzības līdzekḷiem un taisnīgu tiesu, lai saglabātu šo personu tiesības. Arī direktīvas preambulas 33. punktā noteikts, ka direktīva būtiski ietekmē personu tiesības - ne tikai aizdomās turēto vai apsūdzēto personu, bet arī tādu trešo personu tiesības, kurām netiek piemērota kriminālvajāšana. Tādēḷ ir jāparedz konkrēti aizsardzības pasākumi un tiesiskās aizsardzības līdzekḷi, lai šìs direktīvas īstenošanas gaitā nodrošinātu šo personu pamattiesību saglabāšanu. Tas ietver to trešo personu tiesības tikt uzklausītām, kas apgalvo, ka ir attiecīgā ìpašuma īpašnieki, vai kas apgalvo, ka tām ir cita veida īpašuma tiesības ("reālas tiesības", "ius in re"), piemēram, lietojuma tiesības [1].

Salīdzinot Latvijas starptautiskās saistības un kriminālprocesuālo regulējumu par personas iespējām efektīvi realizēt savas tiesības, tika konstatēts, ka ir pamats diskusijai par jautājumu, vai Kriminālprocesa likumā ir paredzēti skaidri aizsardzības pasākumi un tiesiskās aizsardzības līdzekḷi, kas nodrošina personu, kuras nav aizdomās turēto vai apsūdzēto personu statusā, pamattiesību aizsardzību. 
Juris Stukāns. Tiesību pārsūdzēt lēmumu realizācijas problemātika procesā par noziedzīgi iegūtu mantu

\section{Secinājumi}

Novērtējot procesa par noziedzịgi iegūtu mantu kriminālprocesuālo regulējumu, jāsecina, ka tiesību pārsūdzēt lēmumu realizācija procesā par noziedzīgi iegūtu mantu ir ierobežota. Procesa par noziedzīgi iegūtu mantu kriminālprocesuālais regulējums ir nepilnīgs, neskaidrs un pię̧auj iespēju atškịīgi interpretēt tiesību normas, kas iekḷautas Kriminālprocesa likuma 59. nodạ̦ā "Process par noziedzīgi iegūtu mantu". Analizējot tiesu lēmumus par mantas atzîšanu par noziedzīgi iegūtu, tika gūts secinājums, ka process par noziedzīgi iegūtu mantu un tiesības pārsūdzēt rajona (pilsētas) tiesas lēmumu nenodrošina personai iespējas pilnvērtīgi aizstāvēt savas intereses.

Vienā normatīvajā aktā jāpielieto vieni un tie paši principi, veidojot tiesību normas, izṇemot gadījumus, kad atšḳirīga pieeja ir pamatota un tādējādi arī izskaidrojama. Normatīvā akta teksta neskaidrība kalpo par pamatu atzinumam, ka tiesību realizācija tiek ierobežota.

\section{Issues Related to the Rights to Appeal in Proceedings Regarding Criminally Acquired Property}

\section{Abstract}

The research is dedicated to the issues of involved persons' rights to property in proceedings regarding criminally acquired property. During development of this research, the author studied the realisation of involved persons' rights in proceedings regarding criminally acquired property. The research examines Latvian international obligations, which ensure persons rights to property in case of confiscation of criminally acquired property. The research reveals that procedural regulation of proceedings regarding criminally acquired property is incomplete, ambiguous and allows possibility to different interpretations of legal provisions contained in the Criminal Procedure Law Chapter 59 - Proceedings regarding criminally acquired property.

Keywords: proceedings regarding criminally acquired property, rights to appeal court decision, participants in proceedings regarding criminally acquired property. 
Juris Stukāns. Tiesību pārsūdzēt lēmumu realizācijas problemātika procesā par noziedzīgi iegūtu mantu

\section{Literatūra}

1. Eiropas Parlamenta un Padomes 2014. gada 3. aprīla Direktīva 2014/42/ES par nozieguma rīku un noziedzīgi iegūtu līdzekḷu iesaldēšanu un konfiskāciju Eiropas Savienībā. Iegūts no: http:// register.consilium.europa.eu/doc/srv?l=LV\&t=PDF\&f=PE+121+2013+REV+2 [sk. 19.03.2016.].

2. Eiropas Padomes konvencija par noziedzīgi iegūtu līdzekḷu legalizācijas un terorisma finansēšanas novēršanu, kā arī šo līdzekḷu meklēšanu, izṇemšanu un konfiskāciju. 16.05.2005. Starptautisks dokuments. Stājas spēkā 01.06.2010. Latvijas Vēstnesis, 205 (4191), 30.12.2009.

3. Eiropas Padomes konvencija par noziedzīgi iegūtu līdzekḷu legalizācijas novēršanu, meklēšanu, izṇemšanu un konfiskāciju. 15.10.1998. Likums. Stājas spēkā 23.10.1998. Latvijas Vēstnesis, 308/312 (1369/1373), 23.10.1998.

4. Eiropas Savienības Padomes 2005. gada 24. februāra Pamatlēmums 2005/212/TI par noziedzīgi iegūtu līdzekḷu, nozieguma rīku un īpašuma konfiskāciju. Iegūts no: http://www.google.lv/url?s $\mathrm{a}=$ t\&rct=j\&q=\&esrc=s\&source=web\&cd=2\&ved=0ahUKEwiYpPPQjebLAhVTKywKHe9zBcg QFggdMAE\&url=http\%3A\%2F\%2Fwww.ejn-crimjust.europa.eu\%2Fejn\%2Flibshowdocument. aspx\%3FId\%3D439\%26Lang\%3DLV\&usg=AFQjCNH3NMjOCcetFaaZKbOuUdd7UTm8Pg [sk.19.03.2016.].

5. Ekonomiskās sadarbības un attīstības organizācija (OECD). Iegūts no: http://www.mfa.gov. lv/arpolitika/ekonomiskas-attiecibas/starptautiskas-ekonomiskas-organizacijas/ekonomiskassadarbibas-un-attistibas-organizacija-esao [sk. 18.03.2016.].

6. Grozījumi Kriminālprocesa likumā. 08.07.2011. Likums. Stājas spēkā 11.08.2011. Latvijas Vēstnesis, 117 (4515), 28.07.2011.

7. Latvijas Republikas Tieslietu ministrija. Saeimas Juridiskās komisijas priekšsēdētājai I. Čepānes kundzei [vēstule]. Iegūts no: http://titania.saeima.lv/LIVS10/SaeimaLIVS10.nsf/0/73d4418a92 c0cc78c22578b6003cb839/\$FILE/2_1982.pdf [sk.19.03.2016.].

8. Meikališa, Ā., Strada-Rozenberga, K. Pētījums "Mantas konfiskācijas tiesiskais regulējums Latvijā un Eiropas Savienībā, tās izpildes mehānisma efektivitātes nodrošināšana”. Iegūts no: www.tm.gov.lv/lv/ministrija/imateriali/MantKonf.pdf [sk. 19.03.2016.].

9. Rusanovs, E. Procesa par noziedzīgi iegūtu mantu regulējums Kriminālprocesa likumā. Jurista Vārds, 2016; 1 (904): 24.-31. lpp. 


\title{
Atkarības jēdziena interpretācija krimināltiesībās
}

\author{
Jānis Baumanis \\ Rìgas Stradina universitāte, \\ Juridiskā fakultāte, Latvija \\ janis.baumanis@rsu.lv
}

\section{Kopsavilkums}

Mūsdienu sabiedrības jauno izaicinājumu drošības nostiprināšanas klāstā ietilpst arī krimināltiesisko normu pilnveide un pareiza interpretācija. Rakstā pievērsta uzmanība Krimināllikumā izmantotajam jēdzienam "atkarība". Autors sniedz ši jēdziena interpretāciju, skaidrojot normas ar gramatisko, sistēmisko, vēsturisko un teleologisko metodi, un secina, ka krimināltiesībās jēdziens "atkarība" galvenokārt izmantots, lai apzīmētu līdzatkarību, proti, atkarību no cita cilvēka vai atkarību no dažādām vielām. Kaut gan dažu Krimināllikuma normu interpretācijas rezultātā var secināt, ka atkarību klāstā ietilpst arī uzvedības atkarības, piemēram, atkarība no azartspēlēm, tomēr krimināltiesību teorijā un praksē uzvedības atkarības faktiski netiek izceltas un tām uzmanība nav pievērsta.

Analizējot atkarību kā psihologisko kategoriju un atkarību kā krimināltiesisko kategoriju, autors secina, ka krimināltiesībās, nepārbaudot faktiskās atkarības esamību, ir pietiekami konstatēt, ka tiesību normā ir atzīta atkarības esamība.

Atslēgvārdi: noziedzīgs nodarījums, atkarība, cietušais, vainīgais.

\section{levads}

Ikdienā cilvēka uzvedību nosaka daudzi dažādi faktori. Daži no šiem faktoriem spēj laupīt personai patstāvību. Atrašanās šāda faktora ietekmē pie noteiktiem apstākl̦iem rada atkarību, kas var būt saistīta ar noziedzīga nodarījuma izdarīšanu. Mūsdienu sabiedrībā faktoru klāsts, kas var radīt atkarību, nemitīgi pieaug, kas ir jauns izaicinājums drošības nostiprināšanā, tostarp arī krimināltiesību kontekstā.

Atkarība kā krimināltiesiska kategorija, nenoliedzami, saglabā psihologisko aspektu. Krimināllikumā jēdziens "atkarība" tiek izmantots dažādās izpratnēs, piesātinot krimināltiesības ar jautājumiem, uz kuriem atbildes saistītas ar psihologiiju. 


\section{Darba mērķis}

Atklāt Krimināllikumā izmantotā jēdziena "atkarība" saturu, konstatējot tā kopīgās un atšḳirīgās pazīmes ar psihologiijas kategoriju "atkarība".

\section{Materiāls un metodes}

Rakstā, pievēršot uzmanību judikatūrai, krimināltiesību doktrīnai un tiesiskajam regulējumam, izmantota gramatiska, sistēmiska, vēsturiska un teleologiiska metode, lai interpretētu krimināltiesisko kategoriju - atkarību.

\section{Rezultāti}

Latviešu valodā ar jēdzienu "atkarība" tiek saprasta "atrašanās (kāda, kā) varā, ietekmē, patstāvības trūkums" [3, 111]. Šì skaidrojuma iekavās norādītais iezīmē atkarības divējādo izpratni, kas atspoguḷojas arī krimināltiesībās.

Pirmkārt, atkarība kā līdzatkarība, kas izpaužas kā atrašanās citas personas ietekmē (angḷ val. dependence). Šo atkarību krimināltiesībās parasti analizē saistībā ar noziedzịgā nodarījumā cietušo personu. Piemēram, šajā izpratnē atkarība minēta Krimināllikuma 124. panta pirmajā dạ̦ā, kas paredz kriminālatbildību par personas novešanu līdz pašnāvībai vai tās mēgeinājumam, cietsirdīgi apejoties ar cietušo vai sistemātiski pazemojot viņa personisko cieṇu, ja šì persona nav atradusies materiālā vai citādā atkarībā no vainīgā. Savukārt šĩ panta otrā daḷa paredz atbildību par tādām pašām darbībām attiecībā uz personu, kas atradusies materiālā vai citādā atkarībā no vainīgā.

Otrkārt, atkarība kā atrašanās citu faktoru ietekmē (angḷu val. addiction). Krimināltiesībās šādu atkarību parasti analizē saistībā ar noziedzīgu nodarījumu izdarỉjušo personu. Piemēram, šajā izpratnē atkarība minēta Krimināllikuma 58. ${ }^{1}$ panta ceturtās daḷas 5. punktā, kas paredz, ka, nosacīti atbrīvojot no kriminālatbildības, prokurors personai ar tās piekrišanu var uzlikt par pienākumu ārstēties no alkohola, narkotisko, psihotropo, toksisko vielu vai citas atkarības.

Kā redzams, Krimināllikumā abas minētās atkarības izpratnes nav konkretizētas, piel̦aujot iespēju konstatēt arī citas, likumā neminētas atkarības. Ielūkojoties mājaslapā https://tavaatkariba.wordpress.com/, var konstatēt, ka pastāv l̦oti daudz dažādu atkarību veidu, piemēram, apsēstība ar tīrību, darba atkarība (darbaholisms), datorspēḷu un interneta atkarība, iepirkšanās atkarība (šopings), mācī̌anās atkarība (studijholisms), nikotīna atkarība (smēkēěšna), saldumu atkarība, seksuālā atkarība, spẹlu atkarība, velobraukšanas atkarība, èdienatkarība. N̦emot vērā atkarības veidu lielo daudzumu, kā arī to, ka jēdziens "atkarība" krimināltiesībās ir vērtējuma jēdziens, rodas nepieciešamỉba konstatēt pazīmes, kas ḷautu praksē pareizi interpretēt Krimināllikumā lietoto jēdzienu "atkarība". 
Iesākumā autors piedāvā aplūkot psihologijā identificētās atkarības pazīmes. Psiholoǵijas grāmatā "Atkarība: ǵimenes slimība" $[8,1]$ minētas sešpadsmit atkarības (līdzatkarības) pazīmes. N̦emot par pamatu šo iedalījumu un integrējot tajā krimināltiesiskos jēdzienus, var izdalīt noteiktas atkarības un līdzatkarības pazīmes (sk. 1. tabulu).

1. tabula. Atkarības un līdzatkarības pazīmes krimināltiesiskā aspektā

\begin{tabular}{|c|c|c|}
\hline Pazimes & Atkarība & Līdzatkarība \\
\hline 1 & 2 & 3 \\
\hline Kontroles zudums & $\begin{array}{l}\text { Vainīgais zaudē kontroli pār lietotā } \\
\text { alkohola, narkotiku vai citu vielu } \\
\text { daudzumu. Zaudē kontroli pār } \\
\text { situāciju, kurā vielas tiek lietotas. }\end{array}$ & $\begin{array}{l}\text { Cietušais zaudē kontroli pār savām } \\
\text { jūtām pret vainīgo un savu uzvedību. }\end{array}$ \\
\hline Noliegšana & $\begin{array}{l}\text { Vainīgais noliedz, ka ir atkarīgs } \\
\text { no alkohola, narkotikām vai } \\
\text { citām vielām. }\end{array}$ & $\begin{array}{l}\text { Cietušais neatzīst problēmu, norādot, } \\
\text { ka problēmas ir vainīgajai personai. }\end{array}$ \\
\hline Agresija & Verbālā vai fiziskā pret cietušo. & Verbālā vai fiziskā pret vainīgo. \\
\hline Dominējošās jūtas & $\begin{array}{l}\text { Vainīgais izjūt dvēseles sāpes, } \\
\text { vainu, kaunu, naidu vai aizvaino- } \\
\text { jumu. }\end{array}$ & $\begin{array}{l}\text { Cietušais izjūt dvēseles sāpes, vainu, } \\
\text { kaunu, naidu vai aizvainojumu. }\end{array}$ \\
\hline $\begin{array}{l}\text { Tolerances pieau- } \\
\text { gums }\end{array}$ & $\begin{array}{l}\text { Vainīgajam pieaug spēja panest } \\
\text { (izturēt) lielu daudzumu lietoto } \\
\text { vielu. }\end{array}$ & $\begin{array}{l}\text { Cietušajam pieaug spēja izturēt } \\
\text { emocionālās sāpes, kuras sagādā } \\
\text { vainīgais. }\end{array}$ \\
\hline Paǵiru sindroms & $\begin{array}{l}\text { Lai atvieglotu sindromu, vainīgajam } \\
\text { nepieciešama jauna vielu doza. }\end{array}$ & $\begin{array}{l}\text { Pēc šḳiršanās ar vainīgo cietušais } \\
\text { l̦aujas jaunām destruktīvām attiecībām } \\
\text { ar vainīgo. }\end{array}$ \\
\hline Apreibums & $\begin{array}{l}\text { Vainīgajam bieži esošais stāvoklis, } \\
\text { kas rodas, lietojot vielas }\end{array}$ & $\begin{array}{l}\text { Cietušajam bieži esošais stāvoklis, kurā } \\
\text { viňš nespēj mierīgi, saprātīgi, proti, } \\
\text { skaidri spriest. }\end{array}$ \\
\hline Pašnovērtējums & $\begin{array}{l}\text { Zema pašcien,a, kas piel̦auj } \\
\text { vainīgā pašiznīcinošo uzvedību. }\end{array}$ & $\begin{array}{l}\text { Zema pašcienna, kas piel̦auj cietušă } \\
\text { pašiznīcinošo uzvedību. }\end{array}$ \\
\hline Fiziskā veselība & $\begin{array}{l}\text { Vainīgā aknu, sirds, kungóa, } \\
\text { nervu sistēmas slimības. }\end{array}$ & $\begin{array}{l}\text { Hipertensija, galvassāpes, sirds } \\
\text { "neiroze", aritmija, kungǵa čūla. }\end{array}$ \\
\hline $\begin{array}{l}\text { Pavadošie psihiskie } \\
\text { traucējumi }\end{array}$ & Depresija. & Depresija. \\
\hline $\begin{array}{l}\text { Papildu atkarība no } \\
\text { citām vielām }\end{array}$ & $\begin{array}{l}\text { Vainīgajam atkarība no alkohola, } \\
\text { narkotikām, trankvilizatoriem vai } \\
\text { citām vielām var kombinēties. }\end{array}$ & $\begin{array}{l}\text { Līdztekus atkarībai no vainīgā iespējama } \\
\text { atkarība no trankvilizatoriem vai citāmm } \\
\text { vielām. }\end{array}$ \\
\hline $\begin{array}{l}\text { Apziņas apsēstība ar } \\
\text { tieksmju priekšmetu }\end{array}$ & $\begin{array}{l}\text { Vainīgās personas apziṇā dominē } \\
\text { domas par alkoholu, narkotikām vai } \\
\text { citām vielām. }\end{array}$ & $\begin{array}{l}\text { Cietušās personas apziṇā dominē } \\
\text { domas par vainīgo. }\end{array}$ \\
\hline $\begin{array}{l}\text { Attieksme pret } \\
\text { ärstēšanu }\end{array}$ & Vainīgais atsakās ārstēties. & Cietušais atsakās ārstēties. \\
\hline
\end{tabular}


Jānis Baumanis. Atkarības jēdziena interpretācija krimināltiesībās

\begin{tabular}{|l|l|l|}
\hline \multicolumn{1}{|c|}{$\mathbf{1}$} & \multicolumn{1}{|c|}{$\mathbf{2}$} & \multicolumn{1}{c|}{$\mathbf{3}$} \\
\hline $\begin{array}{l}\text { Izveselošanās } \\
\text { apstākḷi }\end{array}$ & $\begin{array}{l}\text { Atturēšanās no vielu lietošanas, } \\
\text { zināšanas par slimības koncepciju, } \\
\text { ilgstoša rehabilitācija. }\end{array}$ & $\begin{array}{l}\text { Vainīgās personas atraidīšana, zināšanas } \\
\text { par līdzatkarības koncepciju, ilgstoša } \\
\text { rehabilitācija. }\end{array}$ \\
\hline $\begin{array}{l}\text { Izveselošanās } \\
\text { efektīvās } \\
\text { programmas }\end{array}$ & $\begin{array}{l}\text { Psihoterapija, 12 soḷu programma, } \\
\text { pašpalīdzības grupas. }\end{array}$ & $\begin{array}{l}\text { Psihoterapija, 12 soḷu programma, } \\
\text { pašpalīdzības grupas. }\end{array}$ \\
\hline Norise & Liels recidīva risks. & Liels recidīva risks. \\
\hline
\end{tabular}

Kā redzams, lai identificētu atkarību, nepieciešams psihisko procesu izvērtējums. Šajā izvērtējumā būtu jāanalizē psihiskie procesi (domas, vēlmes, jūtas u. c.) atkarības rašanās brīdī, atkarības attīstībā, "ārstēšanas" no atkarības procesā, kā arī periodā pēc "ārstēšanas”. Šāds izvērtējums iespējams psihologiskās ekspertīzes ietvaros.

Krimināltiesībās atkarības kā līdzatkarības konstatēšana parasti notiek, analizējot tikai objektīvās pazīmes. Proti, lai konstatētu līdzatkarību, praksē pietiek konstatēt objektīivi esošo vainīgās personas statusu attiecībā pret cietušo. Piemēram, 2006. gada 5. janvāra lēmumā lietā SKK 01-12/06 Latvijas Republikas Augstākās tiesas Senāta Krimināllietu departaments piekrita prokurora viedoklim, ka cietušās atkarība no apsūdzētā ir konstatēta pareizi. Tas izriet no Civillikuma pirmās daḷas otrās nodaḷas trešās apakšnodaļas normām. Minētajā nolēmumā redzams:

"Attiecībā uz apsūdzētā V. I. meitas N. I. atkarību no tēva prokurors vērš uzmanību uz to, ka spriedumos ir norādīts, ka V. I. ir nepilngadīgās meitas tēvs, t. i., persona, no kuras viṇa ir materiāli vai citādā veidā atkarīga. Materiālā atkarība izriet no Civillikuma 179. panta pirmās dạ̦as, un spriedumos ir norādìta arī cietušās cita atkarība no kasatora, kas izriet no radniecības attiecībām. Turklāt saskaṇā ar Kriminālprocesa likuma 125. panta pirmās daḷas 4. punktu šie apstākḷi uzskatāmi par pierādītiem bez papildu procesuālo darbību veikšanas." $[5,1]$

Tātad, ja likumā ierakstīts, ka persona ir līdzatkarīga, tad līdzatkarības fakts ir pierādìts.

Jāatzīst, ka šāda pieeja līdzatkarības konstatēšanai nebūt nenozīmē atkarības kā psihologiskās kategorijas esamību. Šāda praksē esošā atkarības konstatēšanas pieeja ir nostiprināta arī krimināltiesību teorijā. Komentējot Krimināllikuma 48. panta pirmās daḷas 7. punktā paredzēto atbildību pastiprinošo apstākli, ka "noziedzīgais nodarījums izdarīts pret personu, izmantojot tās dienesta, materiālo vai citādu atkarību no vainīgā", tiek norādīts:

“[..] ar dienesta atkarību no vainīgā saprot dienesta, darba, militārās attiecības. Par materiālo atkarību liecina tādas attiecības starp vainīgo un cietušo, kad vainīgajam bijis pienākums sniegt cietušajam būtisku materiālu palīdzību vai cietušais atradies pilnīgā vainīgā apgādībā. Ar citādu atkarību no vainīgā saprot jebkādu tādu situāciju, kad persona jūt savu pienākumu pakḷauties citai personai - atkarību, kas izriet no laulïbas vai radniecības saitēm, attiecības starp pedagogu un skolnieku, ārstniecības personu un pacientu, fiziski nespèjīgu vai garīgi slimu un tā kopēju u. tml.” [1, 217] 
Tātad līdzatkarība krimināltiesību teorijā ir attiecību fakts, kurā vienai personai pret citu personu ir teorētiska vara. Respektīvi, ja pastāv attiecības, kurās vienai personai pret otru personu ir noteikti pienākumi, krimināltiesību teorijā tiek atzīts, ka šādas attiecības ir atkarības fakts. Šāda atkarība kā krimināltiesiskā kategorija nav tas pats, kas ir atkarība kā psihologiskā kategorija.

Runājot par atkarību, kas nav līdzatkarība, tiek izšķirtas fiziologiskās jeb vielu atkarības (substance addictions) un uzvedības atkarības (behavioral addictions).

Aplūkojot atkarību no vielām krimināltiesību kontekstā, tika analizēta Latvijas Republikas Satversmes tiesas 2005. gada 26. janvāra sprieduma lietā Nr. 2004-17-01, kurā izvērtēta Krimināllikuma 253. ${ }^{2}$ panta pirmajā dạ̣ā iekḷautās normas "narkotisko un psihotropo vielu lietošana bez ārsta nozīmējuma", atbilstība Latvijas Republikas Satversmes 96. pantam. Šajā nolēmumā norādīts:

“[..] narkotisko un psihotropo vielu lietošana bez medicīniskām indikācijām, neievērojot ārsta rekomendētās lietošanas devas un termiṇus, rada iespēju attīstīties pārmērīgai šo vielu lietošanai, bet, turpinot to, var rasties atkarība, kas ir hroniska slimība un veidojas daudz ātrāk nekā alkohola atkarība. [..] Var piekrist pieteicējas pārstāvja uzskatam, ka tādas personas, kurām jau ir izveidojusies atkarība, kriminālsoda draudi vien neatturēs no narkotisko un psihotropo vielu lietošanas. Taču indivīdus, kas vēl nav kḷuvuši atkarīgi no narkotiskajām un psihotropajām vielām, šādi draudi varētu motivēt neuzsākt šo vielu lietošanu vai atteikties no tās." [6, 1]

No minētajām atziṇām izriet, ka vielu lietošanas fakts ne vienmēr nozīmē atkarības esamību. Tas jāṇem vērā, piemēram, kad tiek piemērota Krimināllikuma 59. panta ceturtā dal̦a, kas paredz, ka tiesa personu, kas izdarījusi kriminālpārkāpumu vai mazāk smagu noziegumu alkohola, narkotisko, psihotropo vai toksisko vielu atkarības dēḷ, var atbrīvot no soda izciešanas, ja šī persona piekritusi ārstēties no alkohola, narkotisko, psihotropo vai toksisko vielu atkarības. Sods izpildāms, ja persona tiesas noteiktajā laikā nav uzsākusi ārstēšanos vai pēc tam izvairījusies no ārstēšanās.

Kā Krimināllikuma 59. panta ceturtās daḷas trūkumu jāatzīst, ka šì norma neparedz iespēju tiesai personu atbrīvot no soda izciešanas, ja persona izdarījusi kriminālpārkāpumu vai mazāk smagu noziegumu citas atkarības dēl, kas nav alkohola, narkotisko, psihotropo vai toksisko vielu atkarība, ja šī persona piekritusi ārstēties no šīs citas atkarības. Šāda cita atkarība ir minēta Krimināllikuma 58. ${ }^{1}$ panta ceturtās daḷas 5. punktā, kurā noteikts, ka, nosacīti atbrīvojot no kriminālatbildības, prokurors personai ar tās piekrišanu var uzlikt par pienākumu ārstēties ne tikai no alkohola, narkotisko, psihotropo, toksisko vielu atkarības, bet arī no citas atkarības. Šì cita atkarība teorētiski var būt arī uzvedỉbas atkarība, piemēram, atkarība no azartspēlēm vai riskantas uzvedības. Lai gan jāatzīst, ka minētās normas ieviešanas procesā galvenā uzmanība bija pievērsta psihotropo vai toksisko vielu atkarībai.

Lìdz 2004. gada 24. jūnijam Krimināllikuma 58. ${ }^{1}$ panta ceturtās daḷas 5. punktā bija paredzēts pienākums "ārstēties no alkoholisma, narkomānijas vai citas atkarības". 2004. gada 27. maijā tika pieṇemts likums "Grozījumi Krimināllikumā”, kas paredzēja 
izteikt 58. ${ }^{1}$ panta ceturtās dal̦as 5. punktu šãdā redakcijā: "5) ārstēties no alkohola, narkotisko, psihotropo, toksisko vielu vai citas atkarības.” Pamatojot grozijumu nepieciešamību likumprojekta Nr. 592 "Grozījumi Krimināllikumā", anotācijā tika norādīts:

"Likumprojekta "Grozījumi Krimināllikumā" izdošanas mērḳis ir nodrošināt
Krimināllikuma terminologijas atbilstību narkologiskajā dienestā lietotajai Starp-
tautisko statistisko slimību un veselības problēmu klasifikācijas 10. redakcijai,
kurā visas vieliskās atkaribas ir ietvertas sadạ̄ā Psihiski un uzvedības traucējumi
psihoaktīvu vielu lietošanas dēḷ. Klasifikatorā netiek lietoti vārdi "alkoholisms",
"narkomānija" un "toksikomānija", bet galvenais uzsvars likts uz vārdu "atkarība".
Likumprojekts "Grozījumi Krimināllikumā" paredz konkrēti noteikt atkarības
veidus, kā arī nodrošināt terminu vienveidīgu un konsekventu lietojumu normatīvo
dokumentu tekstos atbilstoši juridiskās tehnikas prasībām. Krimināllikuma grozī-
jumos vārdi "alkoholisms, narkomānija vai toksikomānija" tiek aizstāti ar vārdiem
"alkohola, narkotisko, psihotropo vai toksisko vielu atkarība" un vārdi "apreibinošās
vielas" tiek aizstāti ar vārdiem "toksiskās vielas", nodrošinot pilnu aizliegto vielu
uzskatījumu, kas norādīts ārstniecības jomu regulējošos normatīvajos aktos". [7, 1]

Tādējādi, lai nodrošinātu terminu vienveidīgu un konsekventu lietojumu, veiktajā likuma jaunradē analīzei bija pakḷauti vielu atkarības veidi, bet netika pievērsta uzmanība citādām iespējamām atkarībām, tāpēc praksē jārisina jautājums, vai, piemēram, uzvedības atkarības ir pieskaitāmas pie šìm citām atkarībām. Ja ir pieskaitāmas, tad kādi uzvedības atkarības veidi ir atzīstami par tik kaitīgiem, lai uzliktu pienākumu ārstēties no šīs atkarības.

Pie uzvedības atkarībām pieskaitāma arī atkarība no riskantas uzvedības. N̦emot vērā minēto, rodas jautājums, vai ārstēt nevajadzētu personas par, piemēram, $B A S E$ jumping jeb lēkšanu ar izpletni no ēkām, antenām, tiltiem, klintīm un tamlīdzīgiem objektiem, ja konstatēta atkarība no šādas riskantas uzvedības? Šis jautājums cieši saistīts ar jēdziena "atkarība" interpretāciju. Jāatzīst, ka krimināltiesību normas neliek šḳēršlı prokuroram, nosacīti atbrīvojot no kriminālatbildības, personai ar tās piekrišanu uzlikt pienākumu ārstēties no riskantās uzvedības atkarības. Atklāts paliek tikai jautājums, vai Latvijā pastāv iespēja šādu ārstēšanu îstenot praktiski.

Jautājums par ārstēšanos no atkarības var būt svarīgs, ne tikai nosacīti atbrīvojot personu no kriminālatbildības vai atbrīvojot personu no soda izciešanas, bet arī nosakot sodu. Sākot ar nelielu vēsturisku apskatu, jānorāda, ka, komentējot Latvijas PSR Kriminālkodeksa 12. pantu, kurā bija reglamentēta atbildība par dzērumā izdarītu noziegumu (ar grozijumiem pēc stāvokḷa uz 1982. gada 1. martu), P. Stučkas Latvijas Valsts universitātes profesore M. Blūma rakstīja: "Personām, kas izdarījušas noziegumu uz hroniska alkoholisma vai narkomānijas pamata, tiesa līdzās sodam par izdarīto noziegumu var piemērot medicīniska rakstura piespiedu līdzekḷ saskaṇā ar 57. pantu [..]." $[4,63]$ 
Latvijas PSR Kriminālkodeksa 57. pants paredzēja medicīniska rakstura piespiedu līdzekḷu piemērošanu hroniskiem alkoholiḳiem un narkomāniem. Minētā panta komentāros norādìts:

"Alkoholisms un narkomānija ir hroniskas slimības, kas rodas alkoholisko dzērienu vai narkotisko vielu sistemātiskas lietošanas rezultātā. Komentējamais pants vērsts uz to, lai personām, kas izdarījušas noziegumu uz hroniska alkoholisma vai narkomānijas pamata, piemērotu medicīniska rakstura piespiedu līdzekḷus, lai šīs personas vienlaikus ar pāraudzināšanu un labošanos atgūtu veselību." [4, 207]

Arī šobrīd Krimināllikuma 70. pants l̦auj piemērot medicīniska rakstura piespiedu līdzekḷus vienlaikus ar sodu personām, kuras izdarījušas noziedzīgus nodarījumus, būdamas ierobežotas pieskaitāmības stāvoklī. Šajā pantā paredzēts:

“[..] Ja šādu personu notiesā ar brīvības atṇemšanu, ārstēšana notiek tai piemērotās brīvības atṇemšanas vietās. Ja šādu personu notiesā bez brīvības atñemšanas, tiesa uzliek tai par pienākumu ārstēties psihiatriskajā medicīnas iestādē pēc dzīvesvietas."

Kā redzams, Krimināllikuma 70. pantā nav norādes uz atkarību, bet ir norāde uz psihiatrisko medicīnas iestādi, kurā, kā zināms, notiek ārstēšana arī no atkarībām. Tātad, ja praksē tiek konstatēts, ka noziedzīgs nodarījums izdarīts apstākḷos, kuros vainīgās personas uzvedību ietekmēja kāda no atkarībām, būtu jālemj par ierobežotās pieskaitāmības esamību, kā arī par medicīniska piespiedu līdzekḷa piemērošanu šai personai.

Turpinājumā autors vēlas pievērst uzmanību cilvēku tirdzniecības jēdzienam, kurā tiek izmantots vārds "atkarība". Saskaṇā ar Krimināllikuma 154. ${ }^{2}$ panta pirmo daḷu cilvēku tirdzniecība ir ekspluatācijas nolūkā izdarīta personu savervēšana, pārvadāšana, nodošana, slēpšana, izmitināšana vai saṇemšana, lietojot vardarbïbu vai draudus, vai aizvešanu ar viltu vai izmantojot personas atkarību no vainīgā vai tās ievainojamības vai bezpalīdzības stāvokli, vai arī dodot vai saņemot materiāla vai citāda rakstura labumus, lai panāktu tās personas piekrišanu tirdzniecībai, no kuras ir atkarīgs cietušais. Minētā panta trešajā dạ̦ā ir izskaidrots, ka ekspluatācija šã panta izpratnē ir personas iesaistīšana prostitūcijā vai cita veida seksuālā izmantošanā, piespiešana veikt darbu, sniegt pakalpojumus vai izdarìt noziedzīgus nodarījumus, turēšana verdzībā vai citās tai līdzīgās formās (parādu verdzība, dzimtbūšana vai personas cita veida piespiedu nodošana citas personas atkarībā), turēšana kalpībā vai arī personas audu vai orgānu nelikumīga iznemšana.

Tātad, piemēram, personu savervēšana, lai turētu to kalpībā ekspluatācijas nolūkā, izmantojot tās atkarību no vainīgā, ir cilvēku tirdzniecība. Komentējot cilvēku tirdzniecības jēdzienā esošo frāzi: "izmantojot personas atkarību no vainīgā", tiek norādīts, ka var būt

“[..] gan materiāla atkarība, kad cietušais atrodas pilnīgā vainīgā apgādībā vai saṇem no viṇa būtisku materiālu palīdzību, gan arī citāda veida atkarība, kas izriet no laulības vai radniecības, darba vai dienesta attiecībām utt.” [2, 279]. 
N̦emot vērā minēto un vērtējot jaunos izaicinājums drošības nostiprināšanā, būtu apsverams jautājums, vai par cilvēku tirdzniecību nevajadzētu atzìt personas savervēšanu, lai liktu viṇai kalpot reliǵijā vai sektā sludinātai ticībai un to sludinātājiem, izmantojot personas atkarību no minētajiem ticējumiem un tādējādi faktiski no ticības sludinātājiem. Šì nodarījuma kaitīgums kḷust acīmredzams, kad minētajā kalpošanā ietilpst sabiedrībā nepieṇemamas darbības, no kurām kā visradikālāko var minēt neticīgo nonāvēšanu, vai arī piespiedu laulības. Šāda normu interpretācija rada iemeslu diskusijai par to, vai relig̣iju vai sektā sludināto, ja tas būtiski ietekmē cilvēka uzvedību, var atzìt par atkarību.

Meklējot atbildi uz izvirzìto diskutablo tematu, jāpiemin, ka krimināltiesību teorijā tiek izdalīti divi atkarības (līdzatkarības) veidi: vertikālais un horizontālais. Vertikālā atkarība prezumē dominējošās un atkarīgās personas sociālo statusu atšḳirību, kas paredz vai nu iespēju piemērot atkarīgajai personai dažāda rakstura negatīvus pasākumus, kas ierobežo tās gribu vai uzvedību (padotais - priekšnieks, aizdomās turētais izmeklētājs), vai nu iespēju atkarīgo nostādīt tādā situācijā, kurā tā nevar pilnvērtīgi realizēt savas vajadzības (piemēram, materiālā atkarība, kas izriet no apgādības fakta). Horizontālās atkarības gadījumā dominējošai un atkarīgajai personai ir vienāds sociāli tiesiskais statuss (laulātie, kareivji karaspēka daḷā, notiesātie cietumā), tomēr reāli radītās attiecības prezumē vienas personas dominanci pār citu [9,558]. Atkarība no tās vai citas ticības nenoliedzami rada gan vertikālo (ticīgā atkarība no sludinātāja), gan horizontālo atkarību (ticīgā atkarība no cita ticīgā). Vertikālās atkarības ietvaros sludinātais, interpretējot ticības principus un izmantojot savas zināšanas par sludināto, var personai ierobežot gribu vai ietekmēt uzvedību. Savukārt starp ticīgajiem veidojas horizontālā atkarība, kas balstās uz reliǵijā vai sektā sludināto. Abi šie atkarības veidi var tikt izmantoti, lai piespiestu personu isstenot dominējošā cilvēka gribu.

\section{Diskusija}

Interpretējot krimināltiesību normas par cilvēku tirdzniecību, izvērtējumam jāpakḷauj jautājums, vai religịiju vai sektā sludināto, ja tas būtiski ietekmē cilvēka uzvedību, var atzìt par atkarību.

\section{Secinājumi}

1. Analizējot atkarību kā psiholog̣isko kategoriju un atkarību kā krimināltiesisko kategoriju, autors secina, ka krimināltiesībās, nepārbaudot faktiskās atkarības esamību, ir pietiekami konstatēt, ka tiesību normā ir atzìta atkarības esamība.

2. Krimināltiesībās pamatjēdziens "atkarība" izmantots, lai apzīmētu līdzatkarību, proti, atkarību no cita cilvēka, kā arī lai apzīmētu atkarību no dažādām vielām. Lai gan dažu Krimināllikuma normu interpretācijas rezultātā var secināt, ka atkarību klāstā ietilpst arī uzvedības atkarības, piemēram, atkarība no azartspēlēm, tomēr krimināltiesību teorijā un praksē uzvedības atkarības faktiski netiek izceltas un tām uzmanība nav pievērsta. 


\section{Interpretation of the Concept of "Dependency" in Criminal Law}

\section{Abstract}

The increasing range of new challenges of the modern society security also includes improvement and correct interpretation of the Criminal Law norms. The paper focuses on the concept of "dependency" (addiction) used in the Criminal Law. The author provides the interpretation of dependency (addiction) rendering the norms using grammatical, systemic, historical and teleological methods. The author concludes that in Criminal Law the concept of dependency (addiction) is basically used in order to denote interdependency, namely, the dependency on the other person and also in order to denote the dependency (addiction) on different substances. Although by interpreting some of the Criminal Law norms it can be concluded that the dependency range includes also behavioural dependencies, for instance, gambling dependency; however, in the Criminal Law theory and practice behavioural dependencies are actually not highlighted and they are not addressed.

Analysing dependency as a psychological category and dependency as a category of the criminal law, the author draws the conclusion that in Criminal Law for the existence of dependency it is sufficient to ascertain that existence of dependency is recognised by the legal norm, without verifying the existence of the actual dependency.

Keywords: criminal offence, dependence, addiction, victim, causer.

\section{Literatūra}

1. Krastinš̌, U., Liholaja, V. Krimināllikuma komentāri. Pirmā daḷa (I-VIII ${ }^{1}$ nodaḷa). Rīga: Tiesu namu aǵentūra, 2015. 320 lpp.

2. Krastiṇš, U., Liholaja, V., Niedre, A. Krimināltiesības. Sevišḳā daḷa. Trešais papildinātais izdevums. Rīga: Tiesu namu aǵentūra, 2009. 866 lpp.

3. Latviešu valodas vārdnīca. Autoru kolektīvs. Atb. red. D. Guḷevska. Rīga: Avots, 2006. 1216 lpp.

4. Latvijas PSR Kriminālkodeksa komentāri. Autoru kolektīvs J. Dzenīša un A. Niedres red. Rìga: Avots, 1982. 747 lpp.

5. Latvijas Republikas Augstākās tiesas Senāta Krimināllietu departamenta 2006. gada 5. janvāra lēmums lietā SKK 01-12/06. Iegūts no: http://at.gov.lv/lv/judikatura/judikaturas-nolemumuarhivs/senata-kriminallietu-departaments/hronologiska-seciba/2006/ [sk. 29.03.2016.].

6. Latvijas Republikas Satversmes tiesas 2005. gada 26. janvāra spriedums lietā Nr. 2004-17-01. Iegūts no: http://www.satv.tiesa.gov.lv/upload/spriedums_2004-17-01.htm [sk. 29.03.2016.].

7. Likumprojekta Nr. 592 "Grozijumi Krimināllikumā" anotācija. Iegūts no: http://www.saeima. lv/L_Saeima8/index.htm [sk. 29.03.2016.]. 
8. Moskalenko, V. Zavisimost: semeynaya bolezn. (Москаменко, В. Зависимость: семейная болезнь.) Iegūts no: http://bookap.info/othosheniy/moskalenko_zavisimost_semeynaya_ bolezn/g151.shtm [sk. 29.03.2016.].

9. Polnij kurs ugolovnogo prava. Tom 2: Prestuplenija protiv licnosti. Pod. red. A. I. Korobejeva. SPb.: Juridiceskij centr Press, 2008. (Помный курс уголовного права. Том 2. Преступления против кичности. Под реА. А. И. Коробеева. СПб.: ЮриАический центр Пресс, 2008. 682 c.) 


\title{
“Tiesību tikt aizmirstam" piemērošanas un izpratnes problēmas Latvijā
}

\author{
Svetlana Sitņikova \\ Rìgas Stradiña universitāte
}

\section{Kopsavilkums}

"Tiesības tikt aizmirstam" ir samērā jauns tiesību institūts, kura aktualizēšanas priekšnosacījums ir tehnologiju attīstība un globalizācija, kas šobrīd ḷaj padarìt informāciju, tostarp arī personas datus un sensitīvus datus, publiski pieejamu visā pasaulē. Iepriekšminētais rada nepieciešamību veicināt personas datu aizsardzību.

"Tiesības tikt aizmirstam" īpaši tika aktualizētas saistībā ar Eiropas Savienības tiesas lēmumu lietā C-131/12 Google Spain SL, Google Inc. pret Agencia de Protección de Datos, Mario Costeja González (t. s. Google v Spain lieta). Arī Eiropas Cilvēktiesību tiesa saskaras ar jaunām koncepcijām, no kurām viena ir "tiesības tikt aizmirstam".

Veicot pētijumu, tika gūtas šādas atziṇas: Latvijas Republikas normatīvajos aktos paredzētie aizsardzības līdzekḷi, atbildība un sankcijas tikai dą̣ēji veicina "tiesību tikt aizmirstam" ievērošanu. Pētỉjumā iesaistìtās valsts iestādes neapzinās ar fizisko personu datu apstrādi saistītos potenciālos riskus un tos novērsa (veica nepieciešamās izmaiṇas datu apstrādes sistēmās) tikai pēc privātpersonas(-u) iesnieguma saṇemšanas. Šì iemesla dẹl, lai stiprinātu Latvijas iedzìvotāju uzticēšanos valsts iestādēm jautājumā par tiešsaistē atrodamiem datiem un panāktu jaunu pakalpojumu, tostarp arī publisko e-pārvaldības pakalpojumu izmantošanu, tādējādi sekmējot ekonomikas izaugsmi, valsts iestādēm ir jāpārskata sava prakse saistībā ar personas datu apstrādi un pieejamību tiešsaistē.

Atslēgvārdi: Direktīva 95/46/EK, Fizisko personu datu aizsardzības likums, fizisko personu datu apstrāde, "tiesības tikt aizmirstam", personas dati, personas datu aizsardzība, Vispārīgā datu aizsardzības regula. 


\section{levads}

2012. gada 25. janvārī Eiropas Komisija ierosināja Eiropas Savienības datu aizsardzības noteikumu radikālu reformu, lai padarītu tos atbilstošus 21. gadsimtam, t. i., lai nostiprinātu tiesības uz privātumu tiešsaistē un stimulētu Eiropas digitālo ekonomiku. Pamantojums tam ir ne tikai tas, ka "informācijas apstrādes iespēju attīstỉbas ātrums apsteidz to normatìvu izstrādi, kas šos procesus regulē” [21, 5], bet arī tas, ka 27 ES dalībvalstis Eiropas Padomes un Padomes Direktīvas 95/46/EK par personu aizsardzību attiecībā uz personas datu apstrādi un šādu datu brīvu apriti noteikumus ir īstenojušas atšḳirīgi. Viena no galvenajām ar reformu piedāvātajām izmaiṇām ir "tiesības tikt aizmirstam”, kas palīdzēs cilvēkiem labāk pārvaldīt datu aizsardzības riskus tiešsaistē: cilvēki varēs dzēst savus datus, ja nebūs likumīgu iemeslu tos saglabāt.

Raksta mērḳis - izpētīt ar "tiesību tikt aizmirstam” izpratni un realizāciju saistītas īpatnības un iespējamās problēmas Latvijas Republikā (turpmāk tekstā LR).

Materiāls un metodes - attālinātās, individuālās, strukturētās intervijas ar lielāko ziṇu portālu Tvnet.lv, Latvijā vienīgo vietējo sociālo tīklu vietni Draugiem.lv, Datu valsts inspekciju, LR Tiesībsargu, Augstāko tiesu un Tiesu administrāciju.

\section{“Tiesību tikt aizmirstam” izmantošana un ievērošana}

2011. gadā, tieši pirms Eiropas Komisija ierosināja visaptverošu datu aizsardzības noteikumu reformu, lai palielinātu lietotāju iespējas kontrolēt savus datus un samazinātu izmaksas uzṇēmumiem, visās ES dalībvalstīs tika veikts Eurobarometer pētījums. Pētījuma laikā tiešajās intervijās tika aptaujāti 1000 Latvijas iedzìvotāju. Iegūtie dati liecina, ka 47\% Latvijas interneta lietotāju iegādājas preces vai pakalpojumus tiešsaistē (piemēram, ceḷojumus un brīvdienu paketes, apgeērbu, grāmatas, biḷetes, filmas, mūzikas ierakstus, programmatūru, pārtiku), 73\% izmanto sociālās tīklošanas vietnes, 56\% izmanto interneta vietnes, lai apmainītos ar fotogrāfijām, videofailiem un filmām [4].

Ievērības cienīgs ir aptaujas rezultātu salīdzinājums, vērtējot Latvijas iedzīvotāju informētību un uzskatus par to, cik liela ir vinu kontrole pār savu informāciju, ko cilvēki atklāja tiešsaistē. Uz jautājumu "Kā Jums šķiet, cik lielas ir Jūsu iespējas kontrolēt informāciju, ko esat atklājis/-usi sociālās tīklošanas vietnēs, un/vai informācijas apmaiṇas vietnēs ir iespējas, piemēram, šo informāciju mainīt, dzēst vai labot?" 17\% Latvijas sociālo tîklu lietotāju, kas tajos atklāja savu informāciju, atbildēja, ka tiem ir pilnīga kontrole pār savu informāciju, 54\% norādīja, ka viṇiem ir daḷēja kontrole pār savu informāciju, bet $27 \%$ atzīmēja, ka viņiem nav nekādu kontroles iespēju (sk. 1. att.).

Sniedzot atbildes uz šo pašu jautājumu, 26\% ES respondentu atbildēja, ka viniem ir pilnīga kontrole pār savu informāciju, bet $20 \%$ ES respondentu norādīja, ka viniem nav nekādu kontroles iespēju pār savu informāciju [4]. Tas nozīmē, ka ES iedzīvotāii ir vidēji vairāk informēti par savām iespējām kontrolēt informāciju par sevi nekā Latvijas iedzīvotāji. 
Atbildot uz jautājumu "Kā Jums šḳiet, cik lielas iespējas Jums ir kontrolēt informāciju, ko esat atklājis/-usi sociālās tīklošanas vietnēs, un/vai informācijas apmaiṇas vietnēs ir iespējas, piemēram, šo informāciju mainīt, dzēst vai labot?", 12\% Latvijas tiešsaistes pircēju, kas tiešsaistē atklājuši savu informāciju, uzskata, ka viṇiem ir pilnīga kontrole pār savu informāciju, 50\% domā, ka viṇiem ir daḷejja kontrole pār savu informāciju, bet 36\% ir pārliecināti, ka viṇiem nav nekādu kontroles iespēju pār savu informāciju (sk. 2. att.).

Veiktā pētỉjuma rezultāti rāda, ka $27 \%$ Lat vijas sociālo tīklu lietotāju nav informēti par iespējām kontrolēt (mainìt, dzēst vai labot) informāciju par sevi, ko viṇi ir atklājuši sociālās tīklošanas vietnēs. Savukārt 36\% Latvijas tiešsaistes pircēju uzskata, ka viṇiem nav pilnīgi nekādu kontroles iespēju (mainìt, dzēst vai labot) pār informāciju, ko viṇi ir atklājuši sociālās tīklošanas vietnēs un/vai informācijas apmaiņas vietnēs. Tādējādi ir maz ticams, ka personas, kuras šādi ir atbildējušas uz pētījuma jautājumiem, spēj izmantot savas "tiesības tikt aizmirstam".

Pēc 2014. gada 13. maijā publicētā Eiropas Savienības tiesas sprieduma lietā C-131/12 un 2014. gada 29. maijā Google tā juridiskajai nodaḷai pakḷautās īpašās komisijas izveidošanas līdz 2016. gada 15. janvārim Google no Latvijas tika saṇemts 1421 pieprasijjums par datu dzēšanu un Google ir novērtējusi 6176 tīmekḷa adreses. No Lietuvas tika saṇemti 1894 pieprasījumi un novērtētas 7254 tīmekḷa adreses, savukārt no Igaunijas tika saṇemti 2695 pieprasījumi un novērtētas 8784 tīmekḷa adreses [6]. Salīdzinot trīs Baltijas valstu datus, var secināt, ka no Latvijas ir vismazāk pieteikumu.

N̦emot vērā, ka visās trīs Baltijas valstīs pielāgotā Google meklētājprogramma (google.lv, google.lt, google.ee) un tās globālā versija (google.com) ir apmeklētākās interneta vietnes [2], kā arī iepriekšminēto pieprasījumu skaitu, ko Google ir saṇēmusi no Latvijas, Lietuvas un Igaunijas, šì darba autore izvirza divas hipotēzes par situāciju Latvijā:

1) personas Latvijā nav pietiekami informētas par savām "tiesībām tikt aizmirstām";

2) Latvijā personas tiesības uz privātās dzīves neaizskaramību ir ievērotas un labi aizsargātas, tāpēc personām nav nepieciešams vērsties Google, lai izmantotu savas "tiesības tikt aizmirstām".

Lai atbildētu uz jautājumu, kura no minētajām hipotēzēm ir pareiza, būtu nepieciešams ieskatīties 2011. gada Eurobarometer pētījuma datos par Lietuvu un Igauniju. Salīdzinot ar Latvijas $27 \%$ sociālo tīklu lietotāju, kuri nav informēti par iespējām kontrolēt (mainīt, dzēst vai labot) informāciju par sevi, ko viṇi ir atklājuši sociālās tīklošanas vietnēs, šādu personu īpatsvars Lietuvā ir 13\% un Igaunijā 15\% (sk. 1. att.) [4].

Savukārt, salīdzinot ar 36\% Latvijas tiešsaistes pircēju, kuri uzskata, ka viṇiem nav pilnīgi nekādu kontroles iespēju (mainīt, dzēst vai labot) pār informāciju, ko viṇi ir atklājuši sociālās tīklošanas vietnēs un/vai informācijas apmaiṇas vietnēs, Lietuvā un Igaunijā šādu personu îpatsvars ir attiecīgi 18\% un 23\% no aptaujāto skaita (sk. 2. att.) [4]. 
Svetlana Sitņikova. “Tiesību tikt aizmirstam” piemērošanas un izpratnes problēmas Latvijā

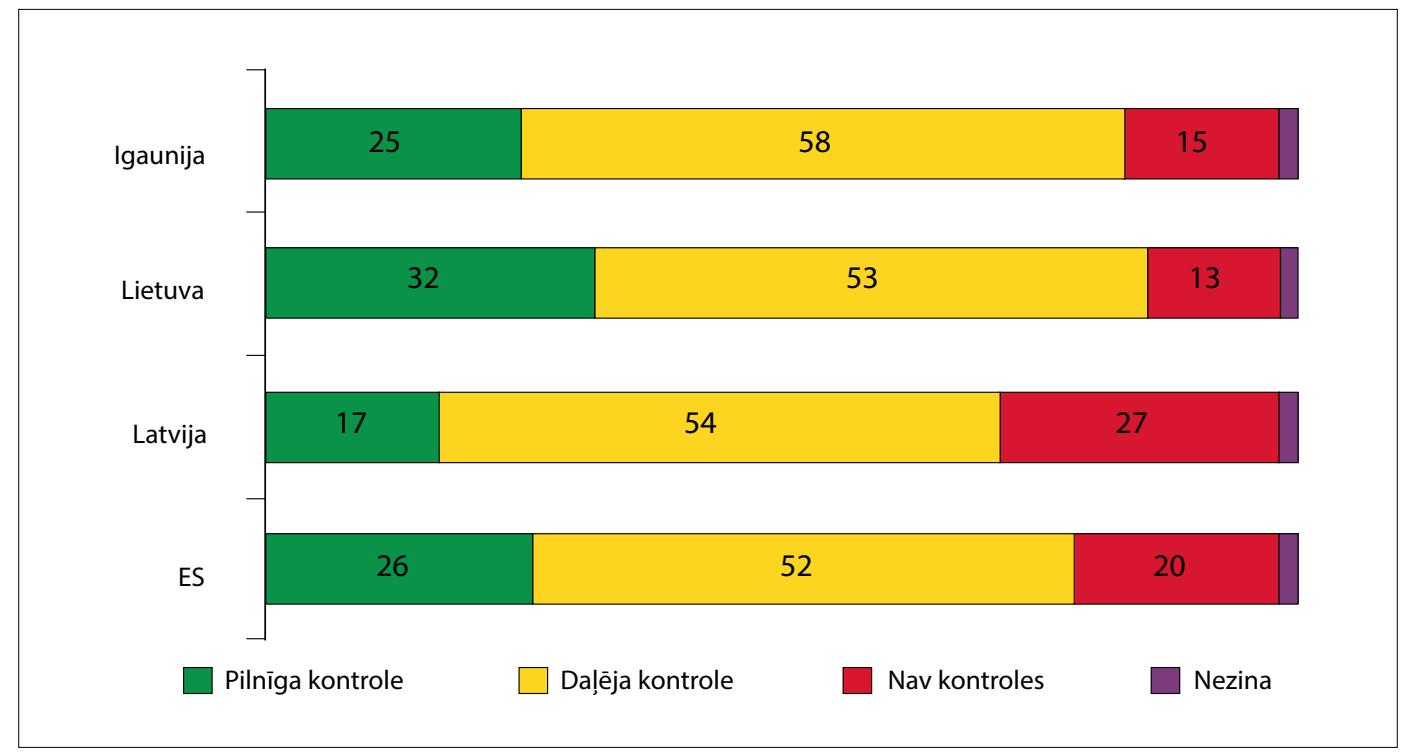

1. attēls. Iedzīvotāju informētỉba par iespējām kontrolēt informāciju tiešsaistē

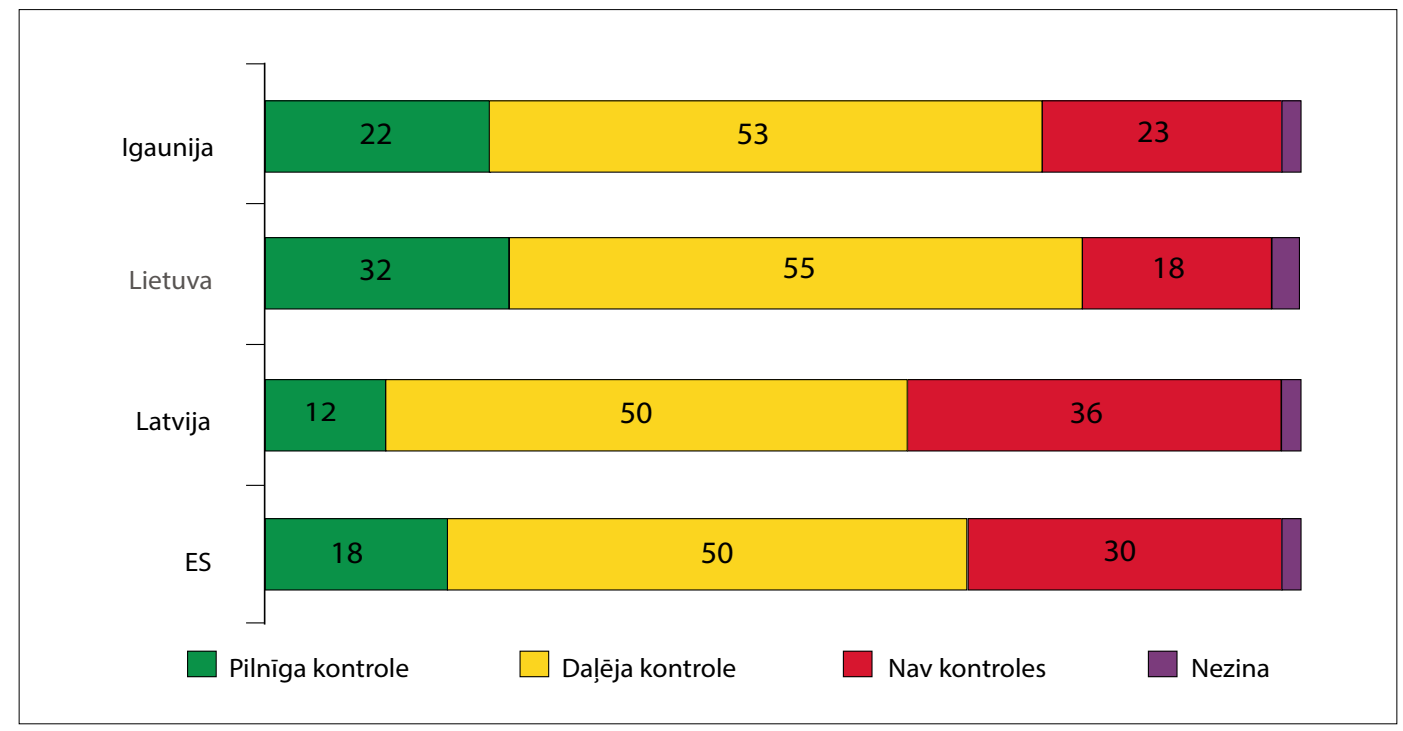

2. attēls. Kontrole pār savu informāciju tiešsaistē, pēc iedzīvotāju domām 
Aplūkojot datus, var secināt, ka personas Latvijā nav pietiekami informētas par savām "tiesībām tikt aizmirstām" un tās arī neizmanto. Iznākumā, pamatojoties uz spēkā esošajām tiesību normām, kas paredzētas gan Direktīvā 95/46/EK, gan LR Fizisko personu datu aizsardzības likumā (turpmāk tekstā FPDAL), par "tiesību tikt aizmirstam" ievērošanu atbildīgām kompānijām (iestādēm, firmām u. c.) šìs tiesības nav jāievēro, ja datu subjekts tajās nav iesniedzis sūdzību par savu tiesību pārkāpumu.

Kaut gan Latvijā personas nav pietiekami informētas par savām "tiesībām tikt aizmirstām”, 2015. gada 29. aprīlī intervijā ar LR Augstāko tiesu saṇemtā informācija liecina, ka pirms 2014. gada 13. maija LR Augstākā tiesa bija saṇēmusi kādas lietas dalībnieku sūdzības, ka viṇu vārds ir bijis atrodams Tiesas kalendārā pēc tam, kad Google.lv mājaslapā ierakstīts konkrētais vārds. N̦emot vērā šĩs sūdzības un mēǵinot novērst šādu situāciju atkārtošanos nākotnē, Augstākā tiesa novērsa iespēju informācijai nokḷūt Google mājaslapā - Augstākās tiesas mājaslapas administrators Google rīkā 2014. gada sākumā iesniedza saites, kuras dzēst no Google datubāzes, lai Tiesas kalendārā pieejamā informācija par tiesā izskatāmajām lietām nebūtu saistìta ar Google meklētāju [10].

Augstākās tiesas 2014. gada sākumā veiktie pasākumi, pamatojoties uz privātpersonas(-u) iesniegumu, liecina par faktu, ka līdz tam privātpersonas nebija vērsušās Augstākajā tiesā un netika izmantojušas savas "tiesības tikt aizmirstām". Savukārt Augstākajai tiesai, kas ir datu pārzinis ar likumā noteiktiem pienākumiem, līdz brīdim, kamēr privātpersonas nebija izmantojušas savas "tiesības tikt aizmirstām" vērsušās pie tās ar lūgumu izbeigt savu personas datu apstrādi -, nebija pienākums šīs tiesības ievērot.

Pēc privātpersonu saṇemtajiem iesniegumiem 2013. gada 18. decembrī Augstākās tiesas priekšsēdētājs apstiprināja kārtību "Informācijas sagatavošanas un publicēšanas kārtība Augstākās tiesas mājaslapā internetā un iekštīklā” [10]. Savukārt Direktīva 95/46/ EK stājās spēkā 1995. gada 24. oktobrī, Latvija ir ES dalībvalsts kopš 2004. gada 1. maija, bet tikai 2014. gada sakumā pēc datu subjekta iesnieguma Augstākās tiesas mājaslapā tika mainīts tiesu informācijas publicēšanas veids un tika noteikti ierobežojumi attiecībā uz Google meklētāju. Rezultātā tika ievērotas arī citu personu tiesības uz privātās dzīves neaizskaramību. Pēc 2014. gada 13. maija Augstākajā tiesā netika saṇemti pieprasijjumi no privātpersonām ar lūgumu, pamatojoties uz FPDAL 16. panta pirmajā dạ̣ā noteiktajām datu subjekta tiesībām, papildināt, izlabot, pārtraukt datu apstrādi vai iznīcināt datus, kurus iestāde publicē tīmekḷa vietnē www.at.gov.lv [10]. Šādai iniciatīvai, pēc raksta autores domām, tomēr būtu jānāk nevis no privātpersonām, kuras, aizsargājot tiesības uz privāto dzīvi, izmanto savas "tiesības tikt aizmirstām", bet no valsts iestādēm, kuru uzdevumos ietilpst noteikta privātpersonu datu aizsardzība un privātās dzīves neaizskaramība.

Šajā situācijā nevar apgalvot, ka citu personu "tiesības tikt aizmirstām", tām pašām šīs tiesības neizmantojot, tika ievērotas, nodrošinot FPDAL 10. panta pirmās dal̦as 3. punktā noteikto personas datu glabāšanas veidu, kas datu subjektu l̦auj identificēt 
konkrētajā laikposmā, kurš nepārsniedz paredzētajam datu apstrādes mērḳim noteikto laikposmu, jo no FPDAL, Direktīvas 95/46/EK, kā arī no EST sprieduma lietā C-131/12 izriet, ka tikai pati persona var izmantot savas "tiesības tikt aizmirstai" un, tikai personai šìs tiesības izmantojot, datu pārzinim ir pienākums šis tiesības ievērot.

Savukārt Tiesu administrācija bija saṇēmusi vienu personas pieprasījumu saistībā ar FPDAL 16. panta pirmajā daḷā noteiktajām tiesībām pirms 2014. gada 13. maija EST sprieduma lietā C-131/12 un vienu personas pieprasījumu pèc šì datuma [8]. Tiesu administrācija apmierināja abu personu pieprasījumus par datu labošanu saistỉbā ar FPDAL 16. panta pirmajā daḷā noteiktajām tiesībām, kurus tā saṇēma pirms un pēc 2014. gada 13. maija EST sprieduma lietā C-131/12 [8]. Tiesu administrācijas veiktās izmaiṇas e-pakalpojumu sadal̦ā "Tiesvedības gaitā", kur, ievadot lietas numuru vai tiesas pavēstes numuru, jebkura persona var iegūt datus par interesējošās lietas tiesvedības gaitu, vairs nav redzama informācija par tiesvedībā iesaistīto pušu vārdiem un uzvārdiem, kā arī uzṇēmumu nosaukumi. Tādējādi arī šajā gadījumā valsts iestāde ir izpildījusi valsts pozitīvo pienākumu veikt pasākumus, lai nodrošinātu privātās dzīves neaizskaramību, nevis ievērojusi personu "tiesības tikt aizmirstām".

Pēc Vispārīgās datu aizsardzības regulas stāšanās spēkā, pamatojoties uz tās 73. panta trešo daļu, neatkarīgi no datu subjekta sūdzības jebkurai struktūrai, organizācijai vai asociācijai, kuras mērḳis ir aizsargāt datu subjektu tiesības un intereses saistībā ar to datu aizsardzỉbu un kura ir izveidota saskaṇā ar dalïbvalsts tiesību aktiem, būs tiesības iesniegt sūdzību jebkuras dalībvalsts uzraudzības iestādē, ja tā uzskata, ka ir noticis personas datu aizsardzības pārkāpums. Tādējādi tiktu aizsargātas to personu intereses, kuras pašas kaut kādu iemeslu dẹḷ savas "tiesības tikt aizmirstām" izmantot nevar.

Šĩ struktūra Latvijā ir LR Tiesībsargs, kura uzdevumos, kā jau tika minēts, ietilpst arī tiesību uz privātās un gimenes dzīves neaizskaramību aizsardzība un veicināšana [17]. 2014. gada 30. decembrī pieteikumā LR Satversmes tiesai Tiesībsargs norādīja, ka iebilst pret Uzturlīdzekḷu garantiju fonda parādnieku personas datu publiskošanu fonda administrācijas mājaslapā un ka apstrīēetā norma neatbilst Satversmes 96. panta vārdiem "Ikvienam ir tiesības uz privātās dzìves [..] neaizskaramību" [18]. Šì ir LR Tiesībsarga pagaidām vienīgā paustā iniciatīva personas datu aizsardzības jomā elektroniskajā vidē, kuru raksta autore ir spējusi atrast LR Tiesībsarga 2011.-2014. gada ziṇojumos un kas nākotnē potenciāli var tikt saistīta ar personu "tiesībām tikt aizmirstām".

K. Vilka rakstā "Bērna tiesību uz privāto dzīvi aizsardzība interneta vidē", kas bija publicēts starptautiskajā zinātniski praktiskajā konferencē "Transformācijas process tiesībās, reǵionālajā ekonomikā un ekonomiskajā politikā", ir sniegusi pētījuma rezultātus. Tā mērkisis bija "aktualizēt vienu no bērnu tiesību aizsardzības aspektiem kā aizsargāt bērna tiesības uz privāto dzīvi un personas datu aizsardzību interneta vidē laikā, kad žurnālisti ne vienmēr izvērtē savas darbības sekas, savukārt bērniem bieži vien ir nepietiekama informācija par iespējām aizsargāt savas tiesības" [23]. 
Pētijuma ietvaros K. Vilka izvērtējusi publikācijas un videofailus, kas satur informāciju par Iḷguciema cietuma Nepilngadīgo nodạı un Bērna un mātes nodạıu, Cēsu audzināšanas iestādes nepilngadīgajiem, kas ir cietuši vai apsūdzēti kriminālprocesā, kā arī intervējusi Iḷguciema cietuma Nepilngadīgo audzināšanas nodạ̣as bijušās ieslodzìtās $[23,165]$. K. Vilka norāda, ka viṇai "radās pārliecība, ka ir situācijas, kad ir aizskartas bērna tiesības uz privāto dzīvi un arī personas datu aizsardzība interneta vidē Latvijā," turklāt "nepietiekama uzmanība tiek pievērsta bērna tiesību uz privāto dzīvi un personas datu aizsardzībai interneta vidē Latvijā un netiek novērtētas pārkāpuma sekas" [23, 166]. "Nepilngadīgie pēc atbrīvošanas no ieslodzỉjuma nereti nonāk situācijās, kad viṇu fotogrāfijas ir atrodamas interneta portālos, liecinot par viṇu atrašanos ieslodzījumā." [23, 166] Kaut gan "nepilngadīgās ieslodzījumā ir izcietušas sodu, tomēr brīvībā šis sods turpinās kā kauna sajūta par faktu, ka teorētiski katrs var uzzināt par viṇu cietumā pavadìto laiku" [23, 168].

Jāuzsver, ka personas datus atḷauts apstrādāt tikai FPDAL 7. pantā minēto nosacījumu iestāšanās gadījumā. K. Vilkas aprakstītajā situācijā neviens no šiem nosacỉjumiem nav iestājies, tāpēc arī FPDAL 7. pantā noteiktais nav ievērots. Pēc iepriekšminētās (2012. gadā Latvijā pastāvošās) situācijas nevar noteikt, vai tiek ievērots FPDAL 16. panta pirmās daḷas otrajā teikumā noteiktais pārziṇa pienākums nekavējoties novērst personas datu, kas ir nepilnīgi, novecojuši, nepatiesi, pretlikumīgi apstrādāti vai arī vairs nav nepieciešami datu vākšanas mērḳim, nepilnības vai pārkāpumus un par to paziṇot trešajām personām, kas iepriekš ir saṇēmušas apstrādātos datus, jo šāds pienākums iestājas tikai un vienīgi, ja to var pamatot datu subjekts. Tieši šādā veidā būtu jāizpaužas "tiesībām tikt aizmirstam".

Taču skaidrs ir fakts - ja personas datu aizsardzības un "tiesību tikt aizmirstam" normas tiktu ievērotas, tad nepastāvētu iepriekšminētās situācijas un K. Vilka raksta secinājumos nevis aicinātu Ieslodzījuma vietu pārvaldi informēt žurnālistus par aizliegumu fotografēt un filmēt bērnus ieslodzījuma vietās, bet gan mudinātu bijušās ieslodzìtās izmantot FPDAL 16. panta pirmajā dạ̦ā noteiktās "tiesības tikt aizmirstam", t. i., tiesības pieprasīt, lai vinu personas datus pārtrauc apstrādāt vai iznīcina tos, jo tie vairs nav nepieciešami datu vākšanas mērḳim. Tātad aktīvi darboties, isstenojot normas pieškirtās iespējas, kas ir tiesību normas izmantošana. Tad datu pārzinim radīsies pienākums nekavējoties novērst šo nepilnību vai pārkāpumu un par to paziṇot trešajām personām, kas iepriekš ir saṇēmušas apstrādātos datus. Tādējādi, balstoties uz likumā noteikto pienākumu, datu pārzinis ievēros bijušo ieslodzìto "tiesības tikt aizmirstām" un vinu sods neturpināsies brīīibā. 


\section{“Tiesību tikt aizmirstam” izpildīšana}

Pēc šĩ raksta autores domām, tieši tas, ka likumā "Par presi un citiem masu informācijas līdzekḷiem” un Elektronisko plašsaziñas līdzekḷu likumā nav paredzēta personas "tiesības tikt aizmirstai" ievērošana, kas ir noteikta FPDAL 16. panta pirmajā daḷā un paredzēta Direktīvas 95/46/EK 12. panta b) punktā, var kavēt "tiesību tikt aizmirstam" izpildīšanu Latvijā.

Pamatojoties uz Eiropas Padomes Parlamentārās asamblejas Rezolūcijā 428 (1970) iekḷautās Deklarācijas par masu komunikācijas medijiem un cilvēktiesībām C daḷas otrajā paragrāfā definētajām tiesībām uz privātumu, Eiropas Padomes Parlamentārās asamblejas Rezolūcijas 1165 (1998) "Par tiesībām uz privātumu" 5. paragrāfā noteikto, ka tiesības kontrolēt savus datus pievienojamas tiesību uz privātumu definīcijai, kā arī Rezolūcijā 1165 (1998) Eiropas Padomes Asamblejas noteikto uzdevumu dalībvalstīm nodrošināt nacionālās likumdošanas ietvaros efektīvas privātuma aizsardzības garantijas, tostarp nodrošināt aizskartās personas tiesības civiltiesiskā kārtībā prasīt iespējamo nodarītā kaitējuma atlīdzību par neatḷauto iejaukšanos personas privātajā dzīvē, un masu mediju pārstāvjiem uzlikt atbildību par tādu materiālu publiskošanu, kas pārkāpj personas privātās dzīves neaizskaramību, var secināt, ka Latvijas likumdevējam likumā "Par presi un citiem masu informācijas līdzekḷiem" un Elektronisko plašsaziṇas līdzekḷ likumā būtu jāparedz personas "tiesības tikt aizmirstai" nodrošināšana.

Likumdevējam normatīvajos aktos, nosakot morālā kaitējuma apmēru, gadījumos, kad personai ir liegtas tiesības kontrolēt savus datus, tātad liegtas tās "tiesības tikt aizmirstai", būtu jāvadās pēc ECT nostājas, kuru tā pauda lietas "Armoniene pret Lietuvu" 46. punktā, nosakot nepieciešamos pasākumus, lai nodrošinātu privātuma aizsardzību. Valsts var ṇemt vērā noteiktus finansiālus standartus, kas balstīti uz valsts ekonomisko situāciju, valsts pat var ierobežot morālā kaitējuma atlīdzības apmēru, taču šādi ierobežojumi nedrīkst ietekmēt personas privātuma vērtību tā, ka tādējādi Eiropas Cilvēktiesību konvencijas 8. pantā nostiprinātās tiesības zaudētu to efektīvo saturu [5].

Administratīvā pārkāpumu kodeksā (turpmāk tekstā APK) paredzētā atbildība par 204. ${ }^{9}$ panta (fiziskās personas datu apstrāde bez registrēšanas), $204 .{ }^{10}$ panta (informācijas nesniegšana Datu valsts inspekcijai) un 204. ${ }^{11}$ panta (personu neakreditēšanās Datu valsts inspekcijā) neievērošanu, pēc šì darba autores domām, nekādi nesekmē "tiesību tikt aizmirstam" izpildīšanu tā vienkāršã iemesla dēl, ka APK par to neizpildīšanu nav paredzēta administratīvā atbildība.

Lìdzīgi var teikt par Krimināllikuma (turpmāk tekstā - KL) 145. panta pirmajā dạ̦ā paredzēto kriminālatbildību par nelikumīgām darbībām ar fiziskās personas datiem, ja ar to radīts būtisks kaitējums. Lai gan likuma "Par Krimināllikuma spēkā stāšanās un piemērošanas kārtību” 23. panta trešā daḷa nosaka, ka ar likumu aizsargāto interešu apdraudējuma kritērijus var noteikt šã likuma pielikumos, šì darba autore nav atradusi ar nelikumīgām darbībām ar fiziskās personas datiem saistītus kritērijus. Tiesa gan, Saeimā 2015. gada 9. aprīlī ir pieṇemti grozījumi KL 23. pantā. 
KL 145. panta otrajā daḷā paredzētā atbildība par nelikumīgām darbībām ar fiziskās personas datiem, ja tās izdarīis personas datu apstrādes pārzinis vai operators ar nolūku atriebties, šantažēt vai mantkārības dēḷ, un šì panta trešajā daḷā paredzētā atbildība par personas datu apstrādes pārziṇa vai operatora, vai datu subjekta ietekmēšanu, pielietojot vardarbỉbu vai draudus vai l̦aunprātīgi izmantojot uzticību, vai ar viltu, lai veiktu nelikumīgas darbības ar fiziskās personas datiem, pēc šì darba autores domām, tiešā veidā uz "tiesībām tikt aizmirstam" neattiecas.

Turpretī, aplūkojot Civillikuma 1779. pantā paredzēto normu, kurā ir noteikts katra pienākums atlīdzināt zaudējumus, ko viņš ar savu darbību vai bezdarbību nodarīiis, personas datu aizsardzības jomā personas privātās dzīves aizskārums ir morāls kaitējums [21, 149]. Tiesu prakses apkopojuma "Morālā kaitējuma atlīdzināšana civillietās" 7.3. nodaḷā ir ietverti tiesu prakses piemēri par morālā kaitējuma atlīdzỉbas noteikšanu gadījumos, kad aizskarts personas privātums, gods un cieņa, kā arī prettiesiski izmantoti personas dati [15, 80-91]. Morālā kaitējuma apmērs tiesu prakses apkopojumā analizētajās civillietās ir no 71 līdz 7114 EUR. Lielākais morālā kaitējuma apmērs gadījumos, kad aizskarts personas privātums, gods un cieņa, kā arī prettiesiski izmantoti personas dati, vērojams publisko personu un politikā iesaistìto personu lietās, kurām, n̦emot vērā vin,u publisko dzīvi, nav "tiesību tikt aizmirstām", tāpēc morālā kaitējuma atlīdzība nepienāktos.

Piemēram, lietā Nr. SKC-1178/2012, kura potenciāli atbilst "tiesībām tikt aizmirstam", prasītājs O. G. cēla tiesā prasību pret komercsabiedrību, lūdzot, pirmkārt, uzdot atbildētājai dzēst informāciju savā datubāzē par prasītāja neesošajiem parādiem divām komercsabiedrībām un aizliegt atbildētājai izplatīt informāciju par prasītāja neesošajiem parādiem trešajām personām, otrkārt, piedzìt atlīdzību par morālo kaitējumu 2000 Ls. Prasītājam tika atteikta kredītkartes izsniegšana un kredita piešķiršana, jo atbildētājas parādnieku datubāzē bijis reǵistrēts prasītāja neapmaksāts parāds. Saskaṇā ar informāciju, kura ir pieejama globālajā tīmeklī, atbildētāja piedāvāja informāciju par prasitāja parādiem jebkurai personai pasaulē latviešu, krievu un angḷu valodā $[15,90]$.

Gan pirmās, gan apelācijas instances tiesa atzina, ka, nepārbaudot un savlaicīgi neizdarot labojumus fizisko personu kredītvēstures datubāzē, atbildētāja kā datu pārzinis FPDAL izpratnē nav nodrošinājusi FPDAL 10. panta pirmās daḷas 4. punktā noteikto pienākumu izpildi, tādējādi pieḷaujot prasītāja tiesību aizskārumu, kas izpaudies dažādu uzṇēmumu atteikumos sniegt pakalpojumus prasītājam. Apelācijas instances tiesa norādīja, ka atlīdzībai ir jābūt pietiekamai, lai veiktu prevencijas funkciju, proti, lai piespriestā summa atturētu atbildētāju un citas personas no līdzīga aizskāruma nodarišanas nākotnē, izvērtējot atbildētājas spēju dot šādu atlīdzību, kā arī ziṇu izplatǐšanas publiskumu un plašumu, aizskāruma smagumu attiecībā pret personu un sekas, ko radījusi godu un cieṇu aizskarošu ziṇu izplatīšana. Augstākā tiesa konstatēja, ka tikusi negatīvi ietekmēta prasīāja reputācija un prasītājs ticis personiski aizskarts, un kā taisnīgu un samērīgu atlīdzību par morālo kaitējumu noteikusi 426,86 EUR. Atbildētāja 
ar kasācijas sūdzību vērsās AT Senātā, taču tas, atzīstot, ka tiesa pamatoti ir konstatējusi prasītāja tiesību aizskārumu un noteikusi samērīgu atlīdzību, kasācijas sūdzību noraidija.

LR spēkā esošie tiesību akti un tiesu prakse saistībā ar personas datu aizsardzību, pēc šì raksta autores domām, neliecina, ka tie sekmēe "tiesības tikt aizmirstam" izpildīšanu, t. i., datu pārziņa aktīvu darbību, lai pildītu FPDAL 16. panta pirmajā dạ̣ā noteiktos pienākumus saistībā ar personas datu apstrādi, datu subjektam pieprasot, lai viṇa personas dati tiek papildināti vai izlaboti vai arī lai tiek pārtraukta to apstrāde, lai tie tiek iznīcināti, ja personas dati ir nepilnīgi, novecojuši, nepatiesi, pretlikumīgi apstrādāti vai arī tie vairs nav nepieciešami datu vākšanas mērḳim. Arī Satversmes 96. panta komentāros to autori atzīst, ka Latvijas likumdevējs vēl nav pieṇēmis vispārēju civiltiesiskās aizsardzības regulējumu privātuma aizskāruma gadījumā [16, 251].

N̦emot vērā iepriekšminēto, raksta autore uzskata, ka Vispārīgās datu aizsardzības regulas projekta VIII nodaḷā paredzētās personas tiesības uz kompensāciju un atbildība (77. pants), sankcijas (78. pants) un administratīvie sodi (79. pants) sekmēs "tiesību tikt aizmirstam" izpildī̌sanu Latvijā.

Aptaujāto uzṇēmumu pārstāvji norāda, ka tie ievēro un izpilda normatīvo aktu prasības neatkarīgi no tā, vai un kāds ir sankcijas lielums [11,12]. Piemēram, Draugiem.lv juridiskais padomnieks U. Pilāberts uzsver, ka "viena no SIA "Draugiem" vērtībām ir godīgums, kas nozīmē arī normatīvo aktu ievērošanu. Ar datiem saistīti jautājumi var būt ḷoti nozīmīgi jebkura uzṇēmuma reputācijai, kas var radīt smagākas sekas nekā Latvijas Administratīvo pārkāpumu kodeksā noteiktā sankcija, tāpēc sankcijas apmērs SIA "Draugiem" noteikti nav bijis kritērijs prasību ievērošanai (tas attiecas arī uz personas "tiesībām tikt aizmirstai")" [12].

Šeit būtu vietā ievērojamā Latvijas civiltiesību speciālista Vasilija Sinaiska atziṇa:

"[..] cik daudz strīdu neizcel̦as dažreiz ap vienu vai otru likuma pantu vienīgi aiz tā iemesla, ka šì panta iztulkojums sastāda pašmērḳi. Bet, attiecināts uz visu tiesību sistēmu kā normatīvi civiltiesisku sabiedrību, likuma pants tūdaḷ iegūst pienācīgu vietu un neapstrīdamu nozìmi." [13, 17]

Ja uzṇēmumi, ievērojot "tiesības tikt aizmirstam", spēj identificēt šīs tiesības un nodrošināt to izpildi pat situācijā, kad LR normatīvajos aktos pastāv nepilnības jautājumā par aizsardzības regulējumu privātuma aizskāruma gadījumā, tad ar tiem var lepoties.

Raksta nākamajā nodaḷā tiks aplūkots, kā valsts institūcijas spēj piemērot "tiesības tikt aizmirstam".

\section{“Tiesību tikt aizmirstam" izpratne un piemērošana}

Lai tiesību norma īstenotu savu regulatīvo funkciju, tās ir jāpiemēro: tiesību normu piemērotājam (piemēram, tiesai), izškirot kādu konkrētu dzīves gadījumu, jāatrod uz šo gadījumu attiecināma tiesību norma un ar tiesību normu piemērošanas aktu (piemēram, tiesas spriedumu) jānosaka un jākonkretizē šajā normā paredzētās tiesiskās sekas. 
Tiesību normas piemērošana ir valsts institūciju aktīva tiesiska darbība, lai piešķirtu tiesību subjektiem normas paredzētās tiesības un pienākumus, izraisot, grozot vai pārtraucot tiesiskās attiecības [13, 19].

Lai izprastu, vai un kā Latvijā tiek piemērotas "tiesības tikt aizmirstam”, šì darba tapšanas laikā Datu valsts inspekcijai, LR Tiesībsargam, Augstākajai tiesai un Tiesu administrācijai tika uzdots jautājums par vinunu "tiesību tikt aizmirstam" izpratni pēc 2014. gada 13. maijā EST sprieduma lietā C-131/12 Google Spain SL, Google Inc. pret Spānijas Datu aizsardzības aǵentūru.

Jāuzsver, ka LR Tiesībsarga dienas kārtībā jautājums par "tiesībām tikt aizmirstam" nav aplūkots [7]. Tādējādi var secināt, ka vismaz pagaidām šì valsts institūcija nav saṇēmusi sūdzības no privātpersonām par šo tiesību ievērošanu un izpildīšanu un pati arī nav izmantojusi savas Tiesībsarga likuma 13. panta 6. punktā noteiktās tiesības ierosināt pārbaudes lietu pēc savas iniciatĩvas, lai personu "tiesības tikt aizmirstām" tiktu ievērotas un izpildītas. Arī Augstākā tiesa nesniedza atbildi par "tiesību tikt aizmirstam" izpratni. Savukārt Tiesu administrācija sniedza atbildi, ka "tiesības tikt aizmirstam" ir tiesības prasìt interneta meklētājprogrammu pakalpojumu sniedzējiem dzēst no rezultātu saraksta, kas tiek atspoguḷots pēc meklējuma veikšanas, izmantojot personas vārdu, saites uz mājaslapām, kuras publicējušas trešās personas un kurās ir informācija saistībā ar šo personu, un ka Tiesu administrācija nenodrošina iespēju iegūt meklēšanas rezultātu sarakstu, meklēšanai izmantojot personas vārdu [8].

Datu valsts inspekcijas pārstāvis atzina, ka, izskatot iesniegtās sūdzības, inspekcija piemēro EST tiesas spriedumā minēto (tā atziṇas), kā tas minēts sprieduma tekstā, turklāt Datu valsts inspekcija piedalās Direktīvas 95/46/EK 29. panta darba grupas darbā un piemēro tās 2014. gada 26. novembrī apstiprinātās vadlīnijas Nr. WP225 [9].

2014. gadā Augstākā tiesa veica izmaiņas Tiesas kalendāra funkcionēšanas sistēmā, Tiesu administrācija veica izmaiņas tiesvedības gaitā (http://www.tiesas.lv/epakalpojumi/tiesvedibas-gaita) sniegtās informācijas apjomā, lai nodrošinātu personas datu aizsardzību. Tas liecina par to, ka pètījumā intervētās valsts iestādes līdz brīdim, kad tās saṇēma privātpersonu sūdzības, nav apzinājušas ar fizisko personu datu apstrādi saistītos potenciālos riskus. Nevar apgalvot, ka ar personas datu aizsardzību saistìtas līdzīgas problēmas pastāv arì citās valsts iestādēs, bet nevar paḷauties uz to, ka citās iestādēs ar personas datu apstrādi tiešsaistē saistìtu problēmu nav. Valsts iestādēm ir jāapzinās problēmas un jāveic atbilstoši personas datu aizsardzības pasākumi, paredzot izmaiṇas gan tiešsaistē publicēto datu apjomā, gan savās sistēmās, kur tiek publicēta informācija.

Šajā rakstā netiek plašāk aplūkots personas koda kā personas datu publiskošanas jautājums internetā; detalizēti par to var lasìt vairāku autoru rakstos $[1,19,20]$. Jāpiebilst, ka diskusija par personas koda publiskošanu tika sākta 2010. gadā, taču risinājums tika rasts 2014. gadā, kad Tieslietu ministrija piedāvāja un valdība akceptēja šādu risinājumu: 


\begin{abstract}
“Saskaṇā ar Informācijas atklātības likuma 5. panta otrās daḷas 4. punktu noteikt MK rīkojumam Nr. 305 "Par uzṇemšanu Latvijas pilsonībā naturalizācijas kārtībā" ierobežotas pieejamības statusu un nepublicēt šos rīkojumus www.mk.gov.lv un oficiālajā izdevumā. Savukārt, lai nodrošinātu sabiedrības tiesības uz informāciju par MK pieṇemtajiem lēmumiem, attiecīgās MK sēdes protokollēmumā varētu norādìt naturalizēto personu skaitu." [19]
\end{abstract}

Piedāvājot iepriekšminēto risinājumu, Tieslietu ministrija vērtēja, no vienas puses, personas vārda, uzvārda un personas koda publicēšanas mērḳi un sabiedrības ieguvumu no šo datu publicēšanas, no otras puses, personas tiesības uz savu personas datu aizsardzību. Jāuzsver, ka arī šìs situācijas risinājums ir meklējams kādas personas iesniegumā: 2014. gada 8. maijā Ministru prezidente izdeva rezolūciju, kurā Tieslietu ministrijai lūgts izvērtēt MK rīkojumu Nr. 305 par personas koda publicēšanu mājaslapā http://www.mk.gov.lv/ un oficiālajā izdevumā "Latvijas Vēstnesis" [19].

L. Velve mağistra darbā "Publiskie iepirkumi Latvijā un to problemātikas risinājumi" uzsvērusi, ka saistībā ar publisko iepirkumu publikācijām bieži ir sastopami pārkāpumi fizisko personu datu aizsardzībā, t. i., personas datu izpaušanā [22, 55]. Pārkāpumi izpaužas, gan ievadot personas datus saturošo informāciju Iepirkumu uzraudzības biroja iepirkumu publikāciju vadības sistēmā, gan arī gadījumos, kad pasūtītāji sadậa par publiskā iepirkuma uzvarētāju norāda personu identificējošu informāciju [22, 57].

Iepriekšminētie valsts institūciju pārkāpumi personas datu aizsardzības jomā, iespējams, pamato Latvijas iedzīvotāju, kuri neuzticas valsts iestādēm saistībā ar tiešsaistē atrodamiem datiem, lielo īpatsvaru: 2012. gadā bija 67\% šādu personu, 2013. gadā 64\% un 2014. gadā - 62\% [14]. Salīdzinot ar ES vidējo neuzticības rādītāju, ir vērojama pozitīva tendence - iedzīvotāju īpatsvars, kuri neuzticas valsts iestādēm saistībā ar tiešsaistē atrodamiem datiem, kopš 2012. gada samazinās, taču mums vēl ir tālu līdz zemākajam rādītājam, kāds ir Somijai (2014. gadā tas bija 25\%). Tātad personas datu apstrādē iesaistītajām LR valsts iestādēm, kā arī šo apstrādi uzraugošām valsts iestādēm vēl ir daudz jāizdara personas datu aizsardzības jomā, nevis jāpaḷaujas uz privātpersonu iniciatīvu.

Augstākās tiesas un Tiesu administrācijas pārstāvji norādīja, ka abu institūciju mājaslapās informācija tiek publicēta atbilstoši likuma "Par tiesu varu" $3 .{ }^{1}$ nodaḷu "Informācijas pieejamība" un MK 2009. gada 10. februāra noteikumiem Nr. 123 "Noteikumi par tiesu informācijas publicēšanu mājaslapā internetā un tiesu nolēmumu apstrādi pirms to izsniegšanas". Aplūkojot abus normatīvos aktus, netika atrasta informācija par termiṇiem, kuros Tiesu informatīvā sistēmā esošie personas dati ir pieejami tiešsaistē. Tātad personas datu aizsardzība, ievērojot "integrētās privātuma aizsardzības" (privacy by design) principu [3], iepriekšminētajos normatīvajos aktos nav paredzēta. 


\section{Secinājumi un priekšlikumi}

Intervētie Latvijas uzṇēmumi un valsts institūcijas ievēro personas "tiesības tikt aizmirstai" un pēc datu subjekta pieprasijuma, pamatojoties uz FPDAL 16. panta pirmajā daḷā noteikto, personas datus izlabo, pārtrauc to apstrādi vai iznīcina tos. Taču, analizējot intervēto valsts institūciju praksi saistībā ar fizisko personu datu apstrādi, var secināt, ka problēma ir daudz dzilāka nekā "tiesību tikt aizmirstam" ievērošana, jo uzskatāmi ir pārkāptas personas tiesības uz datu aizsardzību un tātad arī netiek ievērotas konstitucionālajā līmenī nostiprinātās personas tiesības uz privātās dzìves neaizskaramību. No vienas puses, ir logiiski, ka "tiesības tikt aizmirstam" tiek ievērotas tikai pēc privātpersonas pieteikuma. No otras puses, persona var pat nezināt, ka tās dati tiek apstrādāti un ir publiski pieejami tiešsaistē, tāpēc arī nelūgt, lai datu pārzinis pārtrauc to apstrādi, pamatojot savu lūgumu ar FPDAL 16. panta pirmās daḷas otrajā teikumā noteiktajiem iemesliem.

Internets ir atvērta tehniska platforma, un, tiklīdz dati ir publiskoti, tajā nevar kontrolēt to turpmāku izplatî̌šnu. Tāpēc valstij ir jāspēj ne tikai nodrošināt "tiesības tikt aizmirstam" un dzēst personas datus pamatota pieprasījuma gadījumā, bet arī nepielaut personas datu publicēšanu plašākā apjomā, nekā tas ir nepieciešams, lai sasniegtu legitīmu mērḳi. Tas tāpēc, ka, pamatojoties uz FPDAL 16. panta pirmajā dạ̣ā noteikto, datu pārziņa pienākums ir ne tikai pašam nekavējoties novērst šo pārkāpumu, bet arī paziṇot par to trešajām personām, kas iepriekš ir saṇēmušas apstrādātos datus. Pēc Eiropas Parlamenta un Padomes Vispārīgās datu aizsardzības regulas parakstī̌anas, pamatojoties uz šīs regulas 17. panta otro daḷu, datu pārzinis atbildēs arī par to, lai saites uz šiem personas datiem vai šo datu kopijām, vai atveidojumiem dzēš arī trešās personas. Ši papildu pienākuma ievērošana varētu prasīt lielus laika, cilvēku un materiālos resursus, ja atbilstošā līmenī netiek nodrošināta personas datu aizsardzỉba.

Iedzīvotāju neuzticēšanās iestādēm par tiešsaistē atrodamiem datiem ir samērā augsta. Uzticēšanās trūkuma dēḷ iedzīvotāji var neizmantot jaunus pakalpojumus, tostarp arī publiskos e-pārvaldības pakalpojumus, tāpēc publiskais sektors nevarēs gūt labumu no savu pakalpojumu digitalizācijas. Tādējādi var tikt kavēta ekonomikas izaugsme.

FPDAL 16. panta regulējums izsmeḷoši nosaka privātpersonas "tiesības tikt aizmirstai". Autore uzskata, ka šajā pantā nav nepieciešams atsevišḳi izdalīt "tiesības tikt aizmirstam", jo tajā ir regulētas arī citas datu subjekta tiesības. Taču, lai personas sāktu izmantot savas "tiesības tikt aizmirstām" un šīs tiesības tiktu ievērotas, ir nepieciešama sabiedrības izglītošana. Latvijas iedzīvotāji nav pietiekami informēti par savām "tiesībām tikt aizmirstiem". Fizisko personu (potenciālo datu subjektu) informēšanu sakarā ar fizisko personu datu aizsardzības pasākumiem būtu jāveic gan Datu valsts inspekcijai, gan LR Tiesībsargam. Savukārt Datu valsts inspekcijai būtu jāveic juridisko personu (potenciālo datu apstrādātāju) informēšanas pasākumi. Ja sabiedrība netiks informēta un negūs izpratni par "tiesībām tikt aizmirstam", tās netiks izmantotas un datu pārzinim neradīsies pienākums tās ievērot, kaut arī tas, ka tiešsaistē ir pieejami personas dati, var tikt uzskatìts par indivīda privātās dzīves aizskārumu. 
Lai veicinātu, ka datu pārzinis ievēro personas "tiesības tikt aizmirstai", likumdevējam būtu nepieciešams pien̦emt vispārēju civiltiesiskās aizsardzības regulējumu privātuma aizskāruma gadījumā, uz ko norādìts arī Satversmes 96. panta komentāros. Taču šì raksta autore uzskata, ka jautājumā par personas datu aizsardzību būtu nepieciešams precizēt FPDAL 32. pantā noteiktās personas tiesības saṇemt atbilstīgu atlīdzinājumu, ja, pārkāpjot ši likuma noteikumus, tai ir nodarīts kaitējums vai radīti zaudējumi. Tajā arī jāparedz, no kura šis atlīdzinājums būtu prasāms. Kā jau iepriekš tika minēts, pēc datu publicēšanas tiešsaistē to izplatišsana nav kontrolējama, tāpēc datu subjektam ir nepieciešams zināt, no kura viṇš / viṇa var prasit atlīdzinājumu: vai nu no datu pārziņa, kas sākotnēji publiskojis personas datus, vai no kāda cita.

Lai stiprinātu Latvijas iedzīvotāju uzticēšanos valsts iestādēm par tiešsaistē atrodamiem datiem un panāktu jaunu pakalpojumu, tostarp arī publisko e-pārvaldības pakalpojumu izmantošanu, kā arī sekmētu ekonomikas izaugsmi, Ministru prezidentam, pamatojoties uz Ministru kabineta kārtības ruḷ̦a XVI. daḷu "Ministru prezidenta rīkojumi un rezolūcijas un to izpildes nodrošināšana", saskaṇā ar 224. pantu jāuzdod visām ministrijām veikt vienu no šiem uzdevumiem:

1) izvērtēt ministriju pakḷautībā un pārraudzībā esošo iestāžu informāciju sistēmu tiešsaistē publicēto personas datu nepieciešamību un atbilstību personas datu aizsardzībai, kas noteikta FPDAL. Tāpat kā Tieslietu ministrijai, kas vērtēja vārda, uzvārda un personas koda publicēšanu tiešsaistē, ministrijām, analizējot attiecīgās informāciju sistēmas saistībā ar personas datu publicēšanu tiešsaistē, ir jāvērtē, no vienas puses, personas datu publicēšanas mērḳi un sabiedrības ieguvumi no šo datu publicēšanas, no otras puses, personas tiesības uz savu personas datu aizsardzību. Datu valsts inspekcijai ir jāuzñemas konsultēšanas funkcija;

2) novērtēt personas datu apstrādes atbilstību, kura ir noteikta FPDAL 26. panta otrajā prim daḷā, saskaṇā ar 2015. gada 15. maija MK noteikumiem Nr. 216 "Kārtỉba, kādā sagatavo un iesniedz personas datu apstrādes atbilstības novērtējumu" un ņemot par paraugu iepriekšminēto Tieslietu ministrijas vērtējumu.

Apzinoties faktu, ka pat ES dalībvalstu vidū patlaban nav vienprātības par principa "tiesïbas tikt aizmirstam" ieviešanas formu un ka regulas pien,emšana var aizn,emt vairākus gadus, Latvijai jau šobrīd savos normatīvajos aktos būtu nepieciešams ietvert principus jautājumā par "tiesībām tikt aizmirstam" un datu dzēšanu, kas paredzēti Eiropas Parlamenta un Padomes Vispārīgā datu aizsardzības regulā. Regulas 73. panta trešā daḷa atšçirībā no Direktīvas 95/46/EK 28. panta ceturtās daḷas piešķir tādām iestādēm kā LR Tiesībsargs neatkarīgi no datu subjekta sūdzības tiesības vērsties Datu valsts inspekcijā ar sūdzību, ka ir noticis personas datu aizsardzības pārkāpums. Vispārīgā datu aizsardzības regula nostiprinātu LR Tiesībsarga tiesības ierosināt pārbaudes lietu pēc savas iniciatīvas, kuras noteiktas Tiesībsarga likuma 13. panta 6. punktā. Tādējādi nevis atzinuma vai ieteikuma veidā, bet adresātam saistošā veidā tiktu panākta "tiesību tikt aizmirstam" izmantošana un arī to ievērošana. 
Normatīvajos aktos, kas regulē personas datu saturošas informācijas pieejamību tiešsaistē, ir jāiekḷauj nepārprotamas norādes uz termiṇiem, kuros šāda informācija ir pieejama tiešsaistē un pēc kuru beigām šāda informācija būtu dzēšama. Tādējādi tiktu ievērots "integrētās privātuma aizsardzības" (privacy by design) princips. Piemēram, likuma "Par tiesu varu" 3. nodaḷā "Informācijas pieejamība" un MK 2009. gada 10. februāra noteikumos Nr. 123 "Noteikumi par tiesu informācijas publicēšanu mājaslapā internetā un tiesu nolēmumu apstrādi pirms to izsniegšanas" būtu nepieciešams norādìt termiṇus, kuros Tiesu informatīvā sistēmā esošie personas dati ir pieejami tiešsaistē.

\section{Application and Understanding Problems of the "Right to be Forgotten" in Latvia}

\section{Abstract}

The "right to be forgotten" is a relatively new legal institution and the prerequisite for it are rapid technological developments and globalisation allowing information, including personal data and sensitive data, publicly available worldwide. The above mentioned requires the enhancement of the personal data protection.

The "right to be forgotten" had been brought up to date particularly in relation to the EU Court of Justice decision in case C-131/12 Google Spain SL and Google Inc. v Agencia Española de Protección de Datos (AEPD) and Mario Costeja González. The European Court of Human Rights is being faced with new concepts such as that of the "right to be forgotten".

The following conclusions are drawn when conducting the research: the remedies, liability and sanctions as provided in Latvian regulation only partially contribute to the compliance with the "right to be forgotten". The state institutions interviewed while carrying out this research are not aware of the potential risks concerning processing of personal data and make necessary changes in their data processing systems only in response to the individual/-s application. Therefore, to strengthen the trust of Latvian inhabitants in online data kept by public authorities and to enhance usage of e-government services, thus facilitating economic growth, the public authorities must review their existing practices regarding the processing of personal data and access online.

Keywords: the "right to be forgotten", personal data, processing of personal data, protection of personal data, Directive 95/46/EC, Personal Data Protection Law, General Data Protection Regulation. 


\section{Literatūra}

1. Apine, I. Cik personisks ir personas kods. Jurista Vārds, 32 (627), 10.08.2010.

2. Alexa. Top Sites in Latvia / Lithuania / Estonia. Iegūts no: www.alexa.com/topsites/countries/ LV; www.alexa.com/topsites/countries/LT; www.alexa.com/topsites/countries/EE

3. Eiropas Datu aizsardzības uzraudzītājs. Eiropas Datu aizsardzības uzraudzìtāja atzinums par Komisijas paziņojumu Eiropas Parlamentam, Padomei, Ekonomikas un sociālo lietu komitejai un Regionu komitejai - "Vispusīga pieeja personas datu aizsardzībai Eiropas Savienībā" (2011/C 181/01). Eiropas Savienības Oficiālais Vēstnesis, C 181/1, 22.6.2011.

4. Eurobarometer pētījums. Attieksme pret datu aizsardzību un elektronisko identitāti Eiropas Savienībā. 2011. gada jūnijs. Iegūts no: http://ec.europa.eu/public_opinion/archives/ebs/ ebs_359_fact_lv_lv.pdf; http://ec.europa.eu/public_opinion/archives/ebs/ebs_359_fact_lt_ lt.pdf; http://ec.europa.eu/public_opinion/archives/ebs/ebs_359_fact_ee_en.pdf

5. European Court of Human Rights. Case of Armoniene v. Lithuania No. 36919/02. Strasbourg 25/11/2008. Iegūts no: http://hudoc.echr.coe.int/sites/eng/pages/search.aspx?i=001-89823

6. Google transparency report. European privacy requests for search removals. Iegūts no: https:// www.google.com/transparencyreport/removals/europeprivacy/

7. Intervija - Bagātā, L. "Tiesības tikt aizmirstam” kā tiesības uz privātumu un to izpratne Latvijā (Latvijas Republikas Tiesībsarga birojs, Konsultante komunikācijas un starptautisko attiecību jautājumos). Rīga, 11.05.2015.

8. Intervija - Balševics, E. "Tiesības tikt aizmirstam" kā tiesības uz privātumu un to izpratne Latvijā (Tiesu administrācija, Direktors). Rīga, 12.05.2015.

9. Intervija - Datu valsts inspekcija. "Tiesības tikt aizmirstam" kā tiesības uz privātumu un to izpratne Latvijā. Rīga, 07.05.2015

10. Intervija - Kataja, B. "Tiesības tikt aizmirstam" kā tiesības uz privātumu un to izpratne Latvijā (Augstākās tiesas Komunikācijas nodaḷa). Rīga, 29.04.2015.

11. Intervija - Lunde, Z. "Tiesības tikt aizmirstam" kā tiesības uz privātumu un to izpratne Latvijā. (SIA “TV NET”, Galvenā redaktore). Rìga, 13.05.2015.

12. Intervija - Pilābers, U. "Tiesības tikt aizmirstam" kā tiesības uz privātumu un to izpratne Latvijā. (SIA “Draugiem”, Juridiskais padomnieks). Rīga, 28.04.2015.

13. Juridiskās metodes pamati: 11 soḷi tiesību normu piemērošanā: Rakstu krājums. Dr. hab. iur. prof. Meḷ kiša E. zinātniskajā redakcijā. Rīga: Latvijas Universitāte, 2003, 250 lpp.

14. Kinis, U. "Cyber-Strategic" strategic approach on cybercrime. Future challenges in tracking online criminology. CEPO conference. Latvian Presidency of the Council of the European Union. Rīga, 24 March, 2015.

15. Latvijas Republikas Augstākā tiesa. Morālā kaitējuma atlīdzināšana civillietās. Tiesu prakses apkopojums. Rīga, 2014. Iegūts no: http://at.gov.lv/lv/judikatura/tiesu-prakses-apkopojumi/ civiltiesibas/

16. Latvijas Republikas Satversmes komentāri. VIII nodal̦a. Cilvēka pamattiesības. Autoru kolektīvs prof. R. Baloža zinātniskā vadībā. Rīga: Latvijas Vēstnesis, 2011, 864 lpp.

17. Latvijas Republikas Tiesībsargs. Tiesībsarga biroja darbỉbas jomas. Iegūts no: http://www. tiesibsargs.lv/par-mums/tiesibsarga-birojs/darbibas-jomas 
18. Latvijas Republikas Tiesībsargs. Pieteikums par Uzturlidzekḷ garantiju fonda likuma 5.1 panta atbilstību Satversmes 96. panta vārdiem "Ikvienam ir tiesības uz privātās dzìves (..) neaizskaramību” 2014. gada 30. decembrī. Iegūts no: http://www.tiesibsargs.lv/files/content/ Satversmes_tiesai_pieteikums_UGF_paradnieku_publiskosana_30122014.pdf

19. Matule, S. Atrasts risinājums personas kodu publiskošanas jautājumā. Jurista Vārds, 32 (634), 19.08.2014.

20. Rone, D., Jarinovska, K., Lỉbiņa-Egnere, I., Litvins, G., Ruķers, M., Zeile, O., Austere, L. Personas koda lietošana publiski pieejamos dokumentos. Jurista Vārds, 32 (627), 10.08.2010.

21. Ruḳers, M. Personas datu tiesiskā aizsardzība. Rīga: Biznesa augstskola Turība, 2000, 189 lpp.

22. Velve, L. Publiskie iepirkumi Latvijā un to problemātikas risinājumi: maǵistra darbs. Rīgas Stradiṇa universitātes Juridiskā fakultāte, Rīga, 2014, 106 lpp.

23. Vilka, K. Bērna tiesību uz privāto dzīvi aizsardzība interneta vidē. Starptautiskā zinātniski praktiskā konference "Transformācijas process tiesībās, reǵionālajā ekonomikā un ekonomiskajā politikā” (2012, Rīga, Latvija). Rīga: Baltijas Starptautiskā akadēmija, 2013, 164.-171. lpp. 


\title{
Autoru alfabētiskais rādītājs / Alphabetic List of Authors
}

\author{
Alfejeva, Jel̦ena - 64 \\ Baumanis, Jānis - 86 \\ Gaft, David - 23 \\ Matvejevs, Aleksandrs - 57 \\ Sitņikova, Svetlana - 96 \\ Sumbarova, Marina - 15
}

Stukāns, Juris - 77

Trel̦s, Ëriks - 46

Vilks, Andrejs - 36

Zieliński, Jacek - 7 